\title{
Arbeidsmarktmonitor Metalektro 2004
}

Citation for published version (APA):

de Grip, A., van Loo, J. B., \& Sieben, I. J. P. (2005). Arbeidsmarktmonitor Metalektro 2004. ROA. ROA

Reports No. 5 https://doi.org/10.26481/umarep.2005005

Document status and date:

Published: 01/01/2005

DOI:

10.26481/umarep.2005005

Document Version:

Publisher's PDF, also known as Version of record

\section{Please check the document version of this publication:}

- A submitted manuscript is the version of the article upon submission and before peer-review. There can be important differences between the submitted version and the official published version of record.

People interested in the research are advised to contact the author for the final version of the publication, or visit the DOI to the publisher's website.

- The final author version and the galley proof are versions of the publication after peer review.

- The final published version features the final layout of the paper including the volume, issue and page numbers.

Link to publication

\footnotetext{
General rights rights.

- You may freely distribute the URL identifying the publication in the public portal. please follow below link for the End User Agreement:

www.umlib.nl/taverne-license

Take down policy

If you believe that this document breaches copyright please contact us at:

repository@maastrichtuniversity.nl

providing details and we will investigate your claim.
}

Copyright and moral rights for the publications made accessible in the public portal are retained by the authors and/or other copyright owners and it is a condition of accessing publications that users recognise and abide by the legal requirements associated with these

- Users may download and print one copy of any publication from the public portal for the purpose of private study or research.

- You may not further distribute the material or use it for any profit-making activity or commercial gain

If the publication is distributed under the terms of Article $25 \mathrm{fa}$ of the Dutch Copyright Act, indicated by the "Taverne" license above, 


\title{
Arbeidsmarktmonitor Metalektro 2004
}

\author{
ROA-R-2005/5
}

Andries de Grip

Jasper van Loo

Inge Sieben

\section{Researchcentrum voor Onderwijs en Arbeidsmarkt}

Faculteit der Economische Wetenschappen en Bedrijfskunde Universiteit Maastricht

Maastricht, juni 2005 
ISBN 90-5321-416-X

Sec05.045.doc 


\section{Inhoud}

Bladzijde

Voorwoord

Managementsamenvatting iii

1 Ontwikkelingen in de Metalektro 1

1.1 De conjunctuur 1

1.2 Vergrijzing van het personeelsbestand 3

$\begin{array}{ll}1.3 & \text { Innovaties } \\ & 1.4\end{array}$

$\begin{array}{ll}1.4 & \text { Internationalisering } \\ \end{array}$

2 De structuur van de krimpende werkgelegenheid 19

2.1 De werkgelegenheid blijft krimpen 19

$\begin{array}{ll}2.2 \text { Wie werkt waar? } & 21\end{array}$

$\begin{array}{ll}2.3 \text { Werknemers zonder dienstverband } & 24\end{array}$

3 Arbeidsmarktdynamiek 29

3.1 Instroom, uitstroom en dynamiek in de jaren 2002-2004 29

3.2 Steeds minder nieuwe werknemers 30

3.3 Wie stroomt er uit? 32

$\begin{array}{lll}3.4 & \text { Personeelsverloop en arbeidsmarktdynamiek } 33\end{array}$

$\begin{array}{ll}3.5 & \text { Doorstroom geeft ruimte } \\ \end{array}$

4 Vacatures en de werving van personeel $\quad 41$

4.1 Vacatures 41

4.2 Wie zoekt die vindt? 45

4.3 Het beleid bij wervingsproblemen 46

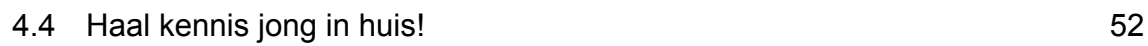

5 Investeren in personeel: de sleutel tot succes? 57

5.1 Cursussen en trainingen: welke en wie betaalt? 57

5.2 Het waarom van scholing en het grote belang van informeel leren 60

$\begin{array}{lll}5.3 \text { Concurreren met kennis } & 63\end{array}$

6 De Metalektro in de toekomst $\quad 67$

6.1 Meer doen met minder personeel $\quad 67$

$\begin{array}{ll}\text { 6.2 Wat verandert er eigenlijk concreet in de bedrijven? } & 72\end{array}$

$\begin{array}{ll}6.3 \text { Kenniseconomie in de Metalektro } & 75\end{array}$

7 De werknemer van de toekomst $\quad 79$

$\begin{array}{ll}7.1 \text { Upgrading } & 79\end{array}$

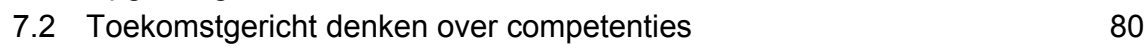

$\begin{array}{ll}7.3 \text { Wie is er inzetbaar? } & 83\end{array}$

7.4 Wat doet het HRM-beleid er toe? 86 
8 Agenda voor de Toekomst

8.1 Competent en breder inzetbaar 89

8.2 Opscholen instroom en zittend personeel 90

8.3 Kennisoverdracht en doorstroom 91

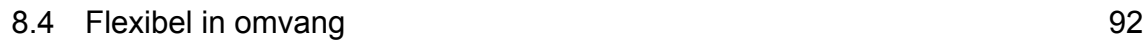

8.5 De Agenda voor de Toekomst: competent en breder inzetbaar 92 


\section{Voorwoord}

Begin 2002 is in opdracht van de Stichting $\mathrm{A}+\mathrm{O}$ de Arbeidsmarktmonitor Metalektro opgezet. Deze monitor geeft inzicht in de actuele en toekomstige ontwikkelingen die van belang zijn voor de metalektrosector. Dit rapport vormt de afsluiting van de derde jaarcyclus van de monitor. Het rapport presenteert de belangrijkste resultaten van het speciaal voor de monitor opgezette Werkgeverspanel Metalektro, aangevuld met informatie over de metalektrosector uit diverse andere bronnen. Daarnaast zijn er in de eerste maanden van 2005 als vervolg op de metingen van het Werkgeverspanel interviews met een aantal deelnemende metalektrobedrijven gehouden. Deze gesprekken hadden als doel meer achtergrondinformatie te verkrijgen over de ontwikkelingen die er in de sector plaatsvinden. Opmerkelijke uitkomsten en uitspraken uit de interviews zijn in dit rapport verwerkt.

In de eerste twee jaar van het werkgeverspanel Metalektro werd er ieder kwartaal een vragenlijst aan de bedrijven voorgelegd. Om de enquêtebelasting wat te verminderen is er in 2004 sprake geweest van 3 metingen. In iedere meting van het werkgeverspanel Metalektro beantwoordt een representatieve groep bedrijven uit de Metalektro een beknopte vragenlijst met vragen over de in- en uitstroom van personeel, het aantal openstaande vacatures, werving en selectie, de inzetbaarheid en de doorstroom van personeel, en de competenties en scholing van het technisch personeel. Er is In 2004 veel aandacht geweest voor het optimaliseren van de vragenlijsten. Door middel van een aantal interviews met bedrijven zijn de vragen flink aangescherpt en meer afgestemd op de behoefte van bedrijven. Dit zal ook in de toekomst blijven gebeuren.

Bij de start van het panel in 2002 zijn alle Metalektrobedrijven, die aangesloten zijn bij de werkgeversorganisatie FME-CWM en vallen onder de CAO Metalektro benaderd om deel te nemen aan het panel. Van de ruim 1.200 bedrijven reageerden er 345 positief. In de loop van de afgelopen 3 jaar heeft een aantal bedrijven zich afgemeld (uitval), maar er zijn ook een aantal nieuwe bedrijven bijgekomen. Om het panel op peil te houden en mogelijk te laten groeien worden alle potentiële deelnemers ieder jaar opnieuw benaderd met het verzoek om mee te doen aan het panel. Ook in de nieuwsbrieven, waarin de resultaten van de enquêtes telkens worden gepubliceerd, worden de bedrijven die nog niet deelnemen aan het werkgeverspanel opgeroepen om dat te gaan doen. Aan de drie metingen die in 2004 gehouden zijn hebben respectievelijk 150, 164 en 160 bedrijven deelgenomen. Als vervolg op de 3 metingen is er aan een aantal bedrijven gevraagd hun medewerking te verlenen aan een face-to-face of telefonisch interview. Met een achttal bedrijven zijn er dergelijke interviews gehouden.

Om na te gaan of de gegevens van deelnemende bedrijven representatief zijn voor alle bedrijven in de Metalektro, is gekeken naar de bedrijfsomvang, bedrijfssector en regio van de aan het werkgeverspanel deelnemende bedrijven. Op basis van deze drie kenmerken zijn de gegevens van de deelnemende bedrijven gewogen. Deze techniek zorgt ervoor dat het Werkgeverspanel Metalektro een representatief beeld 
geeft van de ontwikkelingen in de Metalektro. Om vervolgens uitspraken te kunnen doen over bijvoorbeeld het totale aantal vacatures dat in de Metalektro openstaat, is het aantal vacatures dat bij de deelnemende bedrijven openstaat opgehoogd. Deze ophoging van vacaturecijfers komt overeen met de procedure die het CBS volgt in hun vacature-enquête. Dit heeft als voordeel dat we de ontwikkeling kunnen schetsen van het totale aantal vacatures in de Metalektro. Ook bij de cijfers over de in- en uitstroom van werknemers in de Metalektro is een ophoging tot totaalcijfers voor de hele sector toegepast.

De uitkomsten van de metingen van het werkgeverspanel Metalektro worden elke vier maanden gepubliceerd in een door de Stichting $A+O$ uitgegeven nieuwsbrief. In deze nieuwsbrief wordt gerapporteerd over de actuele arbeidsmarktsituatie en het bij de meting behorende thema. In de loop van 2004 zijn er twee nieuwe elementen in de nieuwsbrief bijgekomen. Er wordt naast de actuele arbeidsmarktsituatie ook gekeken naar de verwachte werkgelegenheidsontwikkelingen op de korte termijn. Daarnaast wordt er door middel van een redactioneel commentaar geprobeerd om te laten zien wat de gevolgen van bepaalde ontwikkelingen zijn en wat dat voor het beleid betekent. Deelnemende bedrijven ontvangen ook nog een "bedrijfsfoto". In dit benchmarkinstrument wordt de positie van het eigen bedrijf vergeleken met het algemene beeld van de bedrijfstak.

Vanaf eind 2004 heeft de Arbeidsmarktmonitor ook een eigen plek op het internet. Via de website www.arbeidsmarktmonitormetalektro.nl kunnen de publicaties worden gedownload en kunnen de deelnemende bedrijven terecht voor meer achtergrondgegevens. Ook voor deze jaarrapportage kunt u op de website terecht.

De Arbeidmarktmonitor Metalektro staat onder leiding van een regiecommissie. De auteurs van dit rapport willen de leden van deze regiecommissie graag bedanken voor hun constructieve commentaar tijdens het gehele proces: Hilde ter Doest (Stichting A+O), Rien Smit (FME-CWM), Patricia Faber (FNV Bondgenoten), Ivo Kuijpers en Quirien van Ojen (Orbis Arbeid en Sociale Zekerheid BV) en Maarten Brouwer (CentERdata). Het veldwerk voor het werkgeverspanel Metalektro is uitgevoerd door Maarten Brouwer, Martijn van der Locht en Vera Toepoel van CentERdata. Sander Dijksman (ROA) werkte mee aan de statistische analyses in dit rapport. Bart Golsteyn (ROA) verzorgde, mede in opdracht van Corus, de regionale prognoses van de verwachte arbeidsmarktinstroom van schoolverlaters. Daarnaast bedanken we de bedrijven die de vragenlijsten getest hebben en suggesties voor verbeteringen in de vraagstellingen hadden. Ten slotte gaat er een woord van dank naar alle bedrijven die gedurende het jaar opmerkingen naar voren brachten gericht op het verbeteren en verder ontwikkelen van de Arbeidsmarktmonitor Metalektro. 


\title{
Managementsamenvatting
}

\author{
Conjunctuur en arbeidsmarkt in 2004
}

$\mathrm{Na}$ enkele jaren van recessie lijkt het erop dat de conjuncturele situatie in de Metalektro zich in 2004 weer wat verbetert. In alle sectoren van de Metalektro neemt de omzet toe en ook voor 2005 zijn de vooruitzichten gunstig. Deze gunstige ontwikkelingen blijken echter (nog) geen positieve invloed te hebben op de ontwikkeling van de werkgelegenheid. In 2004 bleef de werkgelegenheid krimpen. Er gingen steeds minder nieuwe werknemers bij de metalektrobedrijven werken, terwijl de personeelsuitstroom toenam. De krimp is vooral geconcentreerd in de uitvoerende technische functies en de ondersteunende, administratieve of niet-technische verkoopfuncties. Daarentegen krimpt de werkgelegenheid in de hogere functies slechts in een beperkt aantal bedrijven. Dit illustreert dat de krimp in de Metalektro gepaard gaat met aanzienlijke verschuivingen in de functiestructuur.

\section{Vacatures}

In 2004 stonden er in de Metalektro gemiddeld circa 4.000 vacatures open. $\mathrm{Na}$ de stijging van het aantal vacatures in 2003, was er gedurende 2004 sprake van een licht dalend aantal vacatures. Vooral voor de uitvoerende technische functies en de ontwikkeling en engineering functies daalde het aantal vacatures aanzienlijk. Alleen voor leidinggevend technisch personeel en managers was er sprake van een lichte stijging van het aantal vacatures. De meeste vacatures stonden in 2004 minder dan 3 maanden open. Wel is het percentage vacatures dat slechts kort openstond in de loop van 2004 wat gedaald. Dit duidt er op dat het voor sommige bedrijven weer iets moeilijker is geworden om hun vacatures snel in te vullen.

Vanwege de minder goede economische omstandigheden van de afgelopen jaren is het voor bedrijven steeds makkelijker geworden om nieuw personeel aan te trekken. Dit heeft tot gevolg dat bedrijven steeds minder problemen hebben met het vinden van geschikt technisch personeel: in 2002 had nog bijna $20 \%$ van de bedrijven (erg) veel problemen bij het vinden van nieuw personeel; in 2004 was dat gedaald tot slechts $6 \%$ van de bedrijven. Bij deze bedrijven hebben de sollicitanten niet de juiste kwalificaties of onvoldoende werkervaring.

Er zijn maar weinig bedrijven die veel concurrentie ondervinden bij de werving van nieuw personeel. Circa een derde van de bedrijven ondervindt bij de werving enige concurrentie met metalektrobedrijven in de eigen regio. Het gaat dan vooral om hoger opgeleide technici, die soms zo moeilijk te vinden zijn dat ze sommige bedrijven ze 'wegkopen' bij concurrenten.

Flexibele inzet van personeel

Hoewel de meeste bedrijven, vanwege de continuïteit van het bedrijf, liever niet geconfronteerd worden met erg hoge verlooppercentages, vinden veel bedrijven hun 
personeelsverloop in 2004 behoorlijk laag. Er bestaan daardoor immers weinig mogelijkheden om door de in- en uitstroom van personeel het personeelsbestand aan te passen aan de vaak sterk fluctuerende behoefte aan personeel. Ook de interne doorstroom van personeel was in 2004 erg beperkt: In 58\% van de bedrijven was er zelfs helemaal geen doorstroom van personeel. In $70 \%$ van de bedrijven waar technisch personeel wel doorstroomt naar andere functies is er sprake van 'verticale' doorstroom naar hogere functies. In slechts $10 \%$ van de bedrijven is er doorstroom naar functies op een lager niveau. Wat wel opvalt is dat deze 'demotie' in vergelijking met voorgaande jaren wat is toegenomen.

Uit het Werkgeverspanel Metalektro blijkt duidelijk dat verreweg de meeste metalektrobedrijven de benodigde flexibiliteit in het personeelsbestand vooral realiseren door gebruik te maken van tijdelijk ingeleend personeel. In totaal gaat het hier, ondanks de laagconjunctuur, momenteel om ruim 10.000 mensen. Het gaat daarbij vooral om uitvoerend technisch personeel, dat via een uitzendbureau wordt ingehuurd om pieken in de productie op te vangen. Dat bedrijven personeel inlenen in plaats van het zelf in dienst te nemen, heeft echter ook nog een andere reden. Bedrijven maken ook gebruik van ingeleend personeel om deze mensen later zelf in dienst te kunnen nemen. Om het risico bij de werving van personeel te beperken leent men personeel vaak eerst flexibel in, om te kijken of ze in het bedrijf passen. Als deze mensen geschikt blijken te zijn, dan neemt men hen later in dienst.

\section{Belangrijke ontwikkelingen}

De Metalektro is een sector met een grote dynamiek. Er zijn de laatste jaren drie belangrijke ontwikkelingen die de nodige consequenties hebben voor zowel de metalektrobedrijven als hun personeel:

- innovatie;

- een teruglopende werkgelegenheid;

- vergrijzing van het personeelsbestand.

\section{Innovatie}

Allereerst vinden er in veel bedrijven ingrijpende veranderingen plaats in de productietechnieken. Naast veranderingen in het productenpakket (productinnovatie) blijken de metalektrobedrijven met name veel te investeren in procesinnovatie. Op dat vlak is de technologische dynamiek zeer groot. Het overgrote deel van de bedrijven verwacht over 5 jaar met andere productietechnieken te werken dan nu het geval is. Ook blijkt het innovatieve karakter van de sector uit het relatief grote deel van het personeel dat betrokken is bij ontwikkeling en engineering: Voor iedere vier uitvoerende technici is er gemiddeld 1 persoon in dienst die zich bezighoudt met ontwikkeling en engineering. Dat het aantal vacatures voor functies op het vlak van ontwikkeling en engineering afneemt zou er overigens wel op kunnen duiden dat bedrijven dit soort personeel steeds vaker op flexibele basis inzetten.

Naast innovatie op technologisch vlak is er in de Metalektro ook sprake van een innovatie van het HRM-beleid. HRM krijgt in veel bedrijven steeds meer aandacht.

iv 
Momenteel biedt het overgrote deel van de bedrijven opleidingsfaciliteiten aan, die steeds vaker ondersteund worden met een bedrijfsopleidingsplan (BOP). Hoewel dit opleidingsbeleid natuurlijk een sleutelfunctie vervult binnen HRM, is het HRM-beleid in de meeste bedrijven veel breder. Steeds meer bedrijven gebruiken loopbaan- of carrièreplanning $(23 \%)$ en functieroulatie $(48 \%)$ om de kennis van het personeel optimaal te benutten en de competentie-ontwikkeling te stimuleren. Ook stijgt het aantal bedrijven dat door middel van verschillende communicatie-instrumenten (functionerings, beoordelings- en scholingsgesprekken) probeert het HRM-beleid verder uit te bouwen. In 2004 hield een meerderheid van de bedrijven functioneringsgesprekken (90\%), beoordelingsgesprekken (79\%), en scholingsgesprekken (63\%).

De innovatie van de metalektro-industrie hangt natuurlijk samen met de voortschrijdende technologische ontwikkeling, maar ook met het feit dat de Nederlandse Metalektro steeds meer concurrentie ondervindt van bedrijven in het buitenland. Om te kunnen blijven concurreren worden de bedrijven continu uitgedaagd om producten te ontwikkelen die tegen een concurrerende prijs kunnen worden gemaakt. De toegenomen concurrentie met buitenlandse bedrijven, in het bijzonder met bedrijven in de lagelonenlanden, leidt er ook toe dat de Metalektro zich in toenemende mate moet richten op hoogwaardige en innovatieve producten en productieprocessen.

\section{Teruglopende werkgelegenheid}

Een tweede belangrijke ontwikkeling in de Metalektro, die sterk samenhangt met innovatie en de toenemende internationale concurrentie in de sector vormt de structureel teruglopende werkgelegenheid. Hoewel een deel van de teruggang in het personeelsbestand van de metalektrobedrijven de laatste jaren het gevolg is geweest van de minder gunstige conjuncturele omstandigheden, is er ook sprake van een structurele daling van het aantal arbeidsplaatsen. Vanwege de stijging van de productiviteit kunnen metalektrobedrijven immers steeds meer doen met steeds minder personeel. Veel bedrijven zien daarnaast de toenemende internationale concurrentie als oorzaak van een dalende werkgelegenheid. Toch zien weinig bedrijven dit als een reden om de productie te verplaatsen naar het buitenland. Ook de komende jaren zal de werkgelegenheid verder dalen. Tot 2008 zal er naar verwachting ieder jaar circa $2 \%$ van de werkgelegenheid verloren gaan.

\section{Vergrijzing van het personeelsbestand}

Het krimpen van de werkgelegenheid betekent echter niet in dat er de komende jaren geen vraag zal zijn naar nieuw personeel. De vergrijzing van het personeel van veel metalektrobedrijven zal de komende jaren een aanzienlijke vervangingsbehoefte veroorzaken. De vergrijzing van het personeelsbestand in de Metalektro is momenteel dan ook aanzienlijk: Bijna $30 \%$ van het personeel is 50 jaar of ouder. Naar verwachting zal over tien jaar tussen de 15 en $28 \%$ van het huidige personeel vanwege (pré-)pensionering de Metalektro hebben verlaten. 


\section{Gevolgen voor de metalektrobedrijven en hun personeel}

\section{Upgrading}

De verschillende ontwikkelingen waarmee de metalektrobedrijven geconfronteerd worden hebben grote gevolgen voor zowel de bedrijven als hun personeel. Het feit dat productieprocessen complexer en steeds vaker geautomatiseerd worden betekent dat werknemers in de metalektro over steeds meer kennis en vaardigheden moeten beschikken om het werk op een goede manier uit te kunnen voeren. Deze 'upgrading' van de functie-eisen heeft vanzelfsprekend gevolgen voor het gevraagde opleidingsniveau in veel functies. Hierdoor is het gemiddelde opleidingsniveau de laatste jaren behoorlijk gestegen: In 8 jaar tijd steeg het percentage werknemers met een opleiding op MBO niveau of hoger in de metaalsector als geheel (volgens definitie CBS) aanzienlijk, terwijl het werkgelegenheidsaandeel van de werknemers met een VMBO-opleiding of alleen basisonderwijs sterk terugliep van $44 \%$ van het totaal aantal werkenden naar $35 \%$ van het totale personeelsbestand.

\section{Gedragsmatige competenties worden belangrijker}

In wezen is de toename van het gevraagde opleidingsniveau voor veel functies het gevolg van verschuivingen in de vraag naar bepaalde competenties. Om in te schatten om welke competenties het in de toekomst vooral gaat is er in het Werkgeverspanel gevraagd naar de mate waarin bedrijven verwachten dat bepaalde competenties in belang zullen toenemen. Hoewel blijkt dat de bedrijven nog steeds veel waarde hechten aan goede vaktechnische vaardigheden, zijn het toch vooral gedragsmatige vaardigheden die in de toekomst steeds belangrijker zullen worden en waarvoor de metalektrobedrijven in de toekomst bij hun personeel competentietekorten verwachten. Circa $70 \%$ van de bedrijven verwacht dat deze vaardigheden in de toekomst belangrijker zullen worden en maar liefst $86 \%$ van de bedrijven verwacht op deze punten competentietekorten. Het gaat dan vooral om het Probleemoplossend vermogen van het personeel, het kunnen Omgaan met veranderingen, Flexibiliteit en Initiatief (POFI competenties).

De behoefte aan technisch personeel dat deze "POFI"-competenties heeft hangt sterk samen met de vraag naar breed inzetbaar personeel. De flexibele inzet van goede vakkennis in combinatie met de genoemde gedragsmatige competenties is dan ook essentieel voor een optimale inzet van het personeel. Dat betekent dat een "laat-mij-maar-lekker-lassen" mentaliteit, zoals een deelnemer aan het werkgeverspanel het gebrek aan flexibilititeit van het personeel omschreef, niet langer volstaat om aan de vraag naar flexibiliteit van de metalektrobedrijven te voldoen.

\section{(Pré-)pensioenuitstroom en investeringen in oudere werknemers}

Meer dan $40 \%$ van de bedrijven verwacht in de komende 5 jaar een uitstroom van uitvoerend technisch personeel van $5 \%$ of meer als gevolg van de vergrijzing. De sterk toenemende vergrijzing van het personeelsbestand, houdt echter niet alleen in dat de bedrijven rekening moeten houden met een grote uitstroom als gevolg van (pré-)pensionering. De bedrijven moeten er ook voor zorgen dat de oudere vi 
werknemers zo lang mogelijk in dienst kunnen blijven. Dit betekent dat bedrijven ook in hun oudere personeel moeten blijven investeren om hun productiviteit op peil te blijven houden. Sommige bedrijven zullen maatregelen moeten nemen om te voorkomen dat de ervaringskennis van de oudere werknemers niet ineens voor het bedrijf verloren gaat. Toch zien relatief weinig bedrijven de toekomstige uitstroom van personeel als een groot probleem: slechts $13 \%$ van de bedrijven beschouwt het voorkomen van vroegtijdige uitstroom als een speerpunt voor toekomstig HRMbeleid.

\section{HRM-beleid}

\section{Opleidingsbeleid}

De metalektrobedrijven spelen momenteel op verschillende manieren in op de hierboven beschreven ontwikkelingen waarmee ze steeds sterker geconfronteerd worden. Zo leidt de voortdurende upgrading van de functie-eisen er toe dat de er in de metalektrosector bijzonder veel aandacht is voor het kennisniveau van het personeel. De gemiddelde opleidingskosten per bedrijf bedroegen in 2004 bijna $€$ 42.000, oftewel $3 \%$ van de loonsom. Verreweg de meeste bedrijven bieden hun personeel interne $(81 \%)$ of externe $(84 \%)$ cursussen aan. Cursussen op vaktechnisch gebied zijn hierbij vooralsnog het meest populair: in $84 \%$ van de bedrijven worden er door het personeel cursussen gevolgd, die gericht zijn op het verbeteren van vaktechnologische vaardigheden. Daarnaast worden er in veel bedrijven ITopleidingen gevolgd en cursussen op het gebied van veilig gedrag. Andere cursussen die vaak gevolgd worden zijn cursussen in communicatieve vaardigheden, procesgericht werken en commerciële vaardigheden.

Het merendeel van de cursussen (55\%) van het personeel dat werkzaam is in de Metalektro wordt tijdens werktijd gevolgd. Bij $21 \%$ gaat het om cursussen waarbij zowel de werknemers als de bedrijven tijd investeren. Een kwart van de cursussen wordt daarentegen door het personeel geheel in eigen tijd gevolgd. Echter, vrijwel alle cursussen en trainingen worden door de bedrijven of met subsidies bekostigd. Bij de meeste bedrijven is het doel van het opleiden van het personeel het verbeteren van bestaande vaardigheden ( $84 \%$ ) of het aanleren van nieuwe vaardigheden $(69 \%)$ voor de huidige functie. Ook het vergroten van de inzetbaarheid van het personeel $(60 \%)$ of het aanleren van nieuwe vaardigheden voor de verdere loopbaan (54\%) zijn voor veel bedrijven belangrijke opleidingsdoelen.

Hoewel in vergelijking met 2003 minder bedrijven aangeven dat er belemmeringen zijn bij de cursusdeelname van het personeel, wordt de cursusdeelname nog steeds belemmerd door de hoge kosten (30\%) en de verloren werktijd (25\%) die ermee gemoeid zijn. Ook het feit dat de beschikbare cursussen niet aansluiten op de behoefte van het bedrijf belemmert in een aantal bedrijven de cursusdeelname.

Bij het investeren in de competenties van het personeel hoeft het overigens niet alleen te gaan om formele cursussen en trainingen. Ook het informeel leren, "learning-by-doing" of coaching, spelen een belangrijke rol bij de verwerving van 
competenties. Tekorten aan vaktechnische vaardigheden, probleemoplossend vermogen, procesgericht werken en omgaan met veranderingen worden in veel bedrijven weggewerkt door het personeel informeel op de werkplek op te leiden. De coaching van werknemers wordt in veel bedrijven dan ook steeds meer van belang: ruim de helft van de bedrijven ziet het bevorderen van coachend leiderschap als een belangrijk speerpunt voor hun toekomstig HRM-beleid.

Goed kunnen werken in teamverband, zelfstandig werken, flexibiliteit, initiatief, het kunnen omgaan met andere culturen en het leervermogen zijn competenties die vooral door learning-by-doing worden aangeleerd. Competentietekorten op het vlak van IT vaardigheden, leidinggeven, communicatieve vaardigheden, taalvaardigheden en veilig gedrag worden daarentegen door de meeste bedrijven met behulp van formele cursussen en trainingen bijgespijkerd.

Ook de vergrijzing van het personeelsbestand is een belangrijke reden voor bedrijven om te investeren in de competenties van het personeel. Om toekomstige vervangingsproblemen te voorkomen neemt maar liefst $74 \%$ van de bedrijven nieuwe werknemers in dienst die vervolgens in het bedrijf worden opgeleid. Bijna zes van de tien bedrijven besteedt aandacht aan de bij- of omscholing van het huidige personeelsbestand om vervangingsproblemen vóór te zijn.

\section{Erkennen van competenties}

Steeds meer bedrijven proberen ook een goed overzicht te krijgen van de competenties die ze met het huidige personeelsbestand al in huis hebben. Om het gebruik en de ontwikkeling van competenties in goede banen te leiden gebruikt een kwart van de metalektrobedrijven een vorm van competentiemanagement. Daarnaast neemt ook het belang van het erkennen van de competenties van het personeel (EVC) toe. Het feit dat momenteel 10\% van de bedrijven met EVC werkt en dat een kwart van de bedrijven EVC ziet als een speerpunt voor toekomstig HRM-beleid, laat zien dat EVC in een soort "take-off" fase is aangekomen, waarbij het de komende tijd in steeds meer bedrijven in de metalektro gebruikt zal worden.

\section{Wervingsbeleid en HRM}

Bedrijven met moeilijk vervulbare vacatures volgen verschillende wegen om de problemen te beperken. $64 \%$ van de bedrijven laat het personeel overwerken; $68 \%$ besteedt werk uit aan andere Nederlandse metalektrobedrijven en bijna zes van de tien bedrijven investeert in de bij- of omscholing van hun personeel. Daarnaast passen bedrijven hun wervings- en selectiebeleid aan, bijvoorbeeld door uitzendbureaus of andere commerciële wervings- en selectiebureaus in te schakelen $(71 \%)$, door mensen met minder ervaring aan te trekken (55\%) of door scholieren actiever te benaderen $(23 \%)$.

Metalektrobedrijven hebben bij de werving van nieuw personeel een sterke voorkeur voor mensen die afkomstig zijn uit een ander metalektrobedrijf. Deze mensen zijn vaak het snelst inzetbaar. Bovendien zijn bedrijven erop gericht om koste wat kost te 
voorkomen dat er 'risicovolle medewerkers' worden aangetrokken. Steeds meer bedrijven beseffen echter ook dat het voor hun personeelsopbouw belangrijk is om meer schoolverlaters in dienst te nemen. Bovendien kunnen schoolverlaters het voordeel hebben dat ze over meer leervermogen beschikken.

Metalektrobedrijven zetten ook uiteenlopende HRM-instrumenten in om mogelijke toekomstige problemen bij de werving van technisch personeel voor te zijn. Enerzijds proberen ze door het kennisniveau van het eigen personeel op peil te houden en door de inzetbaarheid te bevorderen er voor te zorgen dat het huidige personeelsbestand productief aan de slag kan blijven. Anderzijds realiseren de meeste metalektrobedrijven zich dat het van groot belang is dat ze actief meewerken aan de kwaliteit van de toekomstige instroom in de sector. Door het in dienst nemen van $\mathrm{BBL}-\mathrm{ers}$ en stagiairs van het $\mathrm{MBO}, \mathrm{HBO}$ of de universiteit proberen de bedrijven een deel van de toekomstige behoefte aan personeel nu al zeker te stellen. Ook het grote aantal bedrijven (79\%) dat samenwerkt met onderwijsinstellingen wijst erop dat bedrijven zich bewust zijn van de noodzaak van een instroom van schoolverlaters, die zowel qua richting als niveau aansluit op de benodigde competenties. Bij $41 \%$ van de bedrijven die samenwerken met onderwijsinstellingen is de samenwerking ook direct gericht op het vergroten van de belangstelling voor het technisch onderwijs door het organiseren van 'open dagen'. Gezien het imagoprobleem waarmee het technisch onderwijs en de metalektrosector kampen, zou het wenselijk zijn als meer bedrijven op dit punt met het onderwijs zouden gaan samenwerken. Tenslotte kan een betere samenwerking met onderwijsinstellingen er ook toe bijdragen dat het onderwijs zich beter kan richten op de door bedrijven benodigde competenties.

Dit staat overigens in schril contrast met de te verwachten ontwikkelingen aan de instroomkant van de arbeidsmarkt. Zo blijkt dat het aantal schoolverlaters op VMBOniveau de komende jaren zal toenemen, terwijl er op MBO niveau sprake zal zijn van een dalende instroom. Bij de voor de Metalektro zo belangrijke opleiding MBO elektrotechniek op niveau 4 zal de instroom naar verwachting de komende jaren zelfs met een derde teruglopen. Veel bedrijven verwachten dan ook dat de beschikbaarheid van nieuw technisch personeel de komende jaren flink te wensen over zal laten. Metalektrobedrijven zouden hierop kunnen inspelen door het opscholen van de lager geschoolde schoolverlaters.

Metalektrobedrijven richten hun HRM-beleid in de praktijk vooral op het bevorderen van de kennisverwerving van hun personeel, het realiseren van een grotere interne doorstroom van het personeel en het stimuleren van de inzetbaarheid van het personeel. Vooral de aandacht voor de inzetbaarheid van het personeel is erg groot. $89 \%$ van de bedrijven besteedt in hun HRM-beleid aandacht aan het vergroten van de inzetbaarheid van het personeel. Eenzelfde percentage bedrijven geeft aan dat ze het nog verder bevorderen van de inzetbaarheid zien als een speerpunt voor hun toekomstige HRM-beleid. 
Internationalisering en samenwerking met andere bedrijven

Bedrijven kunnen ook proberen om door verdere internationalisering de ontwikkelingen die op ze afkomen adequaat op te vangen. Toch blijkt dat nog weinig bedrijven gebruik maken van de toenemende internationalisering van de arbeidsmarkt. Zo is het werven van technisch personeel in het buitenland nog beperkt: slechts $15 \%$ van de bedrijven werft wel eens technisch personeel in het buitenland. Bij toekomstige arbeidsmarktknelpunten zou dat overigens wel kunnen veranderen. Wanneer er in de toekomst knelpunten voor bepaalde functies ontstaan, overweegt bijna de helft van de bedrijven actief te gaan werven in het buitenland.

Ook gaan er nog betrekkelijk weinig bedrijven toe over om de productie naar het buitenland te verplaatsen. Niet omdat daar geen geschikt personeel aanwezig zou zijn, maar meestal omdat ze een sterke verantwoordelijkheid voor hun huidige personeel voelen. Voor steeds minder bedrijven is de nabijheid van afzetmarkten een doorslaggevend argument om in Nederland te blijven produceren. Het willen blijven produceren van kwaliteitsproducten en het concurreren met kwaliteit en innovatief vermogen zijn daarentegen wel redenen voor veel bedrijven om in Nederland te blijven. Het blijkt overigens wel dat veel bedrijven nauw samenwerken met buitenlandse partners. Meestal gaat het hierbij om bedrijven in lagelonenlanden, die standaardcomponenten veel goedkoper kunnen produceren dan de Nederlandse metalektrobedrijven.

Een opvallende ontwikkeling van de laatste paar jaar is dat metalektrobedrijven in Nederland ook op de arbeidsmarkt met elkaar gaan samenwerken. Momenteel gaat het al om één derde van de bedrijven, die vooral samenwerken door collegiaal personeel in- en uit te lenen. Eén op de zes bedrijven werkt reeds samen met andere bedrijven in het kader van gezamenlijke wervingsacties. Daarnaast ziet ruim een derde van de bedrijven het intensiveren van de samenwerking met andere bedrijven als een belangrijk speerpunt voor het HRM-beleid in de toekomst.

\section{Agenda voor de Toekomst}

Hoewel de metalektrobedrijven al volop bezig zijn er voor te zorgen dat ze ook op de langere termijn succesvol blijven, zijn er toch enkele lacunes in het huidige HRMbeleid, waarvoor meer aandacht vereist is. We vatten deze aandachtspunten voor het toekomstige arbeidsmarkt- en personeelsbeleid samen in een Agenda voor de Toekomst. De missie van deze Agenda voor de Toekomst voor de Nederlandse metalektro-industrie kan als motto dragen: Competent en breder inzetbaar.

Het realiseren van deze beide doelstellingen zal bepalend zijn voor het toekomstig succes van de Nederlandse metalektrobedrijven. Deze Agenda voor de Toekomst omvat de volgende cruciale bestanddelen:

1. De POFI-Agenda, gericht op het versterken van het competentieniveau van het personeel, met betrekking tot de vier competenties waaraan bedrijven in de toekomst vooral behoefte hebben:

a. probleemoplossend vermogen 
b. omgaan met veranderingen

c. flexibiliteit

d. initiatief

2. Opleidingen en trainingen moeten beter gaan aansluiten op de competenties die bedrijven (in de toekomst) nodig hebben.

3. Naast formele cursussen en trainingen zou er meer aandacht moeten komen voor informele manieren van kennisverwerving, zoals coaching, en 'learning by doing'. Wanneer deze informele scholing gecombineerd wordt met formele cursussen ontstaat er in de bedrijven een 'leerrijke werkomgeving' waarin leren en werken een strategisch geheel vormen.

4. Het opscholen van de instroom van schoolverlaters naar het voor een optimaal functioneren vereiste competentieniveau; Recentelijk heeft de overheid aangegeven dat ook werkenden altijd via het door de overheid bekostigd onderwijs een MBO diploma kunnen halen.

5. Het aandacht blijven houden voor laagopgeleide en oudere werknemers. Wanneer deze groepen niet kunnen worden bijgeschoold tot een hoger niveau, moet er zorg voor gedragen worden dat ze voldoende breed inzetbaar zijn en wel beschikken over de competenties die de bedrijven op de lagere functieniveaus nodig hebben.

6. Het vergroten van de doorstroom van het personeel om de brede inzetbaarheid van het personeel te vergroten. Doorstroom van ouder personeel naar minder belastende functies kan er toe bijdragen dat oudere werknemers langer productief aan het werk kunnen blijven.

7. Verdere uitbouw van HRM-instrumenten die de brede inzetbaarheid bevorderen: loopbaan/carrière planning, functieroulatie, EVC, coachend leidinggeven, competentiemanagement en uitwisseling van werknemers. 



\section{Ontwikkelingen in de Metalektro}

In dit hoofdstuk gaan we in op enkele belangrijke ontwikkelingen in de Metalektrosector. We bespreken achtereenvolgens hoe de conjunctuur zich ontwikkelt, de vergrijzing van het personeelsbestand, de rol van innovatie van producten, productieprocessen en het HRM-beleid, de internationalisering van de productie en de werving van personeel.

\subsection{De conjunctuur}

De afgelopen jaren bevond de metalektrosector zich in een stevige recessie waarin zowel het volume van de afzet als de werkgelegenheid stelselmatig afnamen. De Metalektro volgde daarmee het algehele beeld van een teruglopende bedrijvigheid in Nederland. Naast de conjuncturele neergang van de afgelopen tijd is er in de Metalektro ook een structureel teruglopende werkgelegenheid, vanwege de voordurend toenemende productiviteit. Deze productiviteitsstijging is kenmerkend voor het 'high-tech' karakter van de Metalektro, waarin technologische en mede daaraan gerelateerde organisatorische innovaties van het productieproces het mogelijk maken met steeds minder personeel steeds meer productie te realiseren.

$\mathrm{Na}$ de recessie van de afgelopen jaren lijkt de conjuncturele situatie in de Metalektro zich in 2004 weer wat te verbeteren. Tabel 1.1 laat zien dat in 2004 in alle sectoren in de Metalektro de afzet is toegenomen. Vooral de basismetaalindustrie, de elektrotechnische industrie en de transportmiddelenindustrie kenden een hoge groei. De metaalproductenindustrie kende daarentegen in 2004 slechts een bescheiden groei. Ook de vooruitzichten voor 2005 zijn gunstiger dan voorheen. Voor alle sectoren binnen de Metalektro wordt voor 2005 een groei van het afzetvolume verwacht. Vooral voor de transportmiddelenindustrie en de elektrotechnische industrie zijn de verwachtingen, met een verwachte groei van (ruim) $5 \%$, gunstig.

Tabel 1.1

Veranderingen in afzetvolume in de verschillende sectoren binnen de Metalektro, 2003-2005

\begin{tabular}{|c|c|c|c|}
\hline Sector & $\begin{array}{r}2003 \\
\%\end{array}$ & $\begin{array}{r}2004 \\
\%\end{array}$ & $\begin{array}{r}2005 \\
\text { (verwachtingen) } \\
\%\end{array}$ \\
\hline Basismetaalindustrie & 1,0 & 9,5 & 2,5 \\
\hline Metaalproductenindustrie & 2,5 & 2,0 & 2,5 \\
\hline Machine industrie & $-0,5$ & 4,5 & 2,0 \\
\hline Elektrotechnische industrie & $-5,5$ & 7,5 & 5,0 \\
\hline Instrumenten en optische industrie & $-1,0$ & 4,0 & 3,0 \\
\hline Transportmiddelenindustrie & 1,0 & 8,5 & 5,5 \\
\hline
\end{tabular}

Bron: FME-CWM Conjunctuurenquête (2003 en 2004)

Ondanks de betere vooruitzichten op de afzetmarkt blijft de werkgelegenheid in de Metalektro krimpen. In 2004 daalde de werkgelegenheid in vier van de zes sectoren van de Metalektro. In de transportmiddelenindustrie daalde de werkgelegenheid met 
maar liefst $6,5 \%$. Doordat de bedrijven in deze sector de afgelopen jaren hun personeelsbestand al zoveel hebben laten krimpen, gaat de verbeterende conjunctuur gepaard met een grote vraag naar nieuw personeel. Voor deze sector wordt voor 2005 dan ook een werkgelegenheidstoename van maar liefst 4\% verwacht. In de instrumenten en optische industrie zal de werkgelegenheid naar verwachting in 2005 gelijk blijven. Voor de overige sectoren in de Metalektro wordt een bescheiden werkgelegenheidskrimp verwacht. Hieruit blijkt opnieuw dat de werkgelegenheidsonwikkeling in de Metalektro sterk naijlt ten opzichte van de afzetontwikkeling. De sterke stijging van de arbeidsproductiviteit in de afgelopen jaren is voor een deel ook gerealiseerd door de rek uit het personeelsbestand te halen. Daarom zal de vraag naar nieuw personeel ongetwijfeld weer stijgen wanneer het vertrouwen in de toekomst weer toeneemt.

Uit gesprekken met een aantal deelnemers aan het Werkgeverspanel Metalektro blijkt dat de verwachtingen met betrekking tot de conjunctuur voor de komende jaren sterk afhangen van de branche waarin de bedrijven actief zijn. Met enkele bedrijven die vanwege het hoge exportaandeel in de productie minder gevoelig zijn voor de Nederlandse conjunctuur, gaat het de laatste jaren erg goed. Deze bedrijven verwachten dat dit de komende jaren ook zo zal zijn. Een ander bedrijf verwacht echter, vanwege de huidige beperkte orderportefeuille, weer problemen na 2006. Sommige bedrijven verwachten vanwege de hoge Nederlandse loonkosten moeilijkheden om met het buitenland te concurreren, en verwachten daardoor in de komende jaren weinig omzetgroei en een stagnerende of dalende werkgelegenheid. Maar de bedrijven zitten vanzelfsprekend niet stil en proberen actief in te spelen op de problemen en kansen die op hen afkomen. Sommige bedrijven geven aan dat ze bepaalde gestandaardiseerde delen van de productie uitbesteden aan het buitenland. Andere bedrijven zien meer in het betreden van nieuwe markten. Zo gaf een personeelsfunctionaris van een high-tech bedrijf dat zich bezighoudt met besturingssystemen aan dat erover gedacht wordt om in de toekomst ook actief te worden op de markt voor medische zorg. Een bedrijf uit de transportmiddelensector verwacht op korte termijn een aantal nieuwe klanten: "Daarom zal er bij ons, in tegenstelling tot het algemene beeld van een teruglopende werkgelegenheid in de automotive, de komende jaren sprake zijn van een groeiend personeelsbestand".

De verwachting dat er in de toekomst waarschijnlijk weinig sprake zal zijn van een structurele uitbreiding van het personeelsbestand wordt gedeeld door vrijwel alle bedrijven waarmee gesprekken zijn gevoerd. Een bedrijf dat sterk aan het internationaliseren is door delen van de productie naar landen als Polen en Hongarije uit te besteden, verwacht dat de werkgelegenheid in Nederland "alleen maar minder wordt". Een metalektrobedrijf dat naar eigen zeggen geen high-tech bedrijf is, gaf aan dat ze geen groeiende werkgelegenheid verwacht doordat "de Nederlandse maakindustrie een moeilijke tak van sport is geworden". Een ander bedrijf gaf aan dat het beleid van het moederbedrijf er op gericht is om "meer te doen met minder mensen". Overigens betekent de structureel teruglopende werkgelegenheid niet dat er in de komende jaren geen vraag naar nieuwe arbeidskrachten zal zijn. Sommige bedrijven verwachten dat er als gevolg van de vergrijzing van het personeelsbestand 
op de middellange termijn weer krapte op de arbeidsmarkt zal ontstaan, vooral voor functies op middelbaar en hoger niveau.

Tabel 1.2

Ontwikkeling personeelsbestand in de verschillende sectoren binnen de Metalektro, 2003-2005

\begin{tabular}{lrrr}
\hline Sector & 2003 & 2004 & $\begin{array}{r}2005 \\
\text { (verwachtingen) } \\
\%\end{array}$ \\
& $\%$ & $\%$ & $-0,5$ \\
Basismetaal & & $-1,0$ & $-1,0$ \\
Metaalproducten & $-3,0$ & $-3,5$ & $-3,0$ \\
Machine-industrie & $-3,0$ & $-4,5$ & 0 \\
Elektrotechnisch & 0 & 0 & 4,0 \\
Instrumenten en optische industrie & $-9,0$ & 1,5 & \\
Transportmiddelen & 1,0 & $-6,5$ &
\end{tabular}

Bron: FME-CWM Conjunctuurenquête (2003 en 2004)

\subsection{Vergrijzing van het personeelsbestand}

Een ontwikkeling die de komende jaren een belangrijke rol zal spelen in de metalektrobedrijven is de vergrijzing van het personeelsbestand. Tabel 1.3 geeft per functiecategorie een overzicht van de door de bedrijven verwachte personeelsuitstroom als gevolg van (pré-)pensionering voor de komende vijf jaar.

Tabel 1.3

Verwacht personeelsverloop vanwege (pré)pensioen voor de komende vijf jaar, 2004 (\% bedrijven)

\begin{tabular}{|c|c|c|c|c|c|c|}
\hline \multirow[t]{2}{*}{$\begin{array}{l}\text { Verwacht } \\
\text { uitstroom- } \\
\text { percentage }\end{array}$} & \multirow[t]{2}{*}{$\begin{array}{r}\text { Uitvoerende } \\
\text { technische } \\
\text { functies } \\
\%\end{array}$} & $\begin{array}{l}\text { Leiding- } \\
\text { gevende } \\
\text { technische } \\
\text { functies }\end{array}$ & \multirow{2}{*}{$\begin{array}{r}\text { Technisch } \\
\text { opgeleide } \\
\text { verkopers } \\
\%\end{array}$} & \multirow{2}{*}{$\begin{array}{r}\text { Ontwikkeling } \\
\text { en } \\
\text { engineering } \\
\%\end{array}$} & \multirow{2}{*}{$\begin{array}{r}\text { Hoger } \\
\text { manage- } \\
\text { ment } \\
\%\end{array}$} & \multirow{2}{*}{$\begin{array}{r}\text { Ondersteunende, } \\
\text { administratieve of } \\
\text { niet-technische } \\
\text { verkoopfuncties } \\
\%\end{array}$} \\
\hline & & $\%$ & & & & \\
\hline $0-5 \%$ & 56 & 85 & 89 & 91 & 90 & 88 \\
\hline $6-10 \%$ & 29 & 4 & 3 & 4 & 3 & 2 \\
\hline $11-15 \%$ & 7 & 2 & 1 & 2 & 1 & 1 \\
\hline $16-20 \%$ & 7 & 6 & 1 & 1 & 0 & 5 \\
\hline $21 \%$ of meer & 1 & 3 & 6 & 2 & 6 & 4 \\
\hline
\end{tabular}

Bron: ROA/Werkgeverspanel Metalektro 2004

Het blijkt dat er vooral voor het uitvoerend technisch personeel de komende jaren een behoorlijke uitstroom verwacht wordt. Meer dan $40 \%$ van de bedrijven verwacht in de komende vijf jaar een uitstroom van uitvoerend technisch personeel van $5 \%$ of meer. Voor de overige functies is de verwachte uitstroom beperkter. Hier geeft de grote meerderheid van de bedrijven aan dat het uitstroompercentage ten gevolge van (pré-)pensionering $5 \%$ of minder zal bedragen. Uit achterliggende gegevens 
blijkt dat de verwachte pensioenuitstroom in bedrijven in de regio West wat groter is dan in de andere regio's.

Uit de gesprekken met deelnemers aan het Werkgeverspanel kwam naar voren dat de vergrijzingsproblematiek niet in alle bedrijven even ernstig is. Zo gaf een bedrijf waarin de werkgelegenheid de komende jaren krimpt aan dat de werknemers die met pensioen gaan niet worden vervangen. Een bedrijf waarin de uitstromende oudere werknemers wel vervangen worden zag juist problemen omdat het bij de uitstroom gaat om laagopgeleide werknemers, die vervangen moeten worden door minimaal middelbaar opgeleide werknemers. Aangezien dit bij veel bedrijven speelt, verwacht het bewuste bedrijf voor deze groep werknemers de komende jaren weer een krapte op de arbeidsmarkt.

Een grote uitstroom van ervaren werknemers kan tot problemen leiden bij de metalektrobedrijven. Voor sommige bedrijven zal het moeilijk zijn om de juiste mensen aan te trekken, om het vertrekkende personeel te vervangen. Bij andere bedrijven kunnen er problemen ontstaan wanneer er als gevolg van de uitstroom belangrijke ervaringskennis verloren gaat. In tabel 1.4 wordt er een overzicht gegeven van de ernst van de problemen. Zoals te verwachten viel, zullen de meeste problemen zich voordoen bij de vervanging van uitvoerend technisch personeel. $14 \%$ van de bedrijven geeft aan de komende vijf jaar veel problemen te verwachten bij de vervanging van uitvoerend technisch personeel dat met (pré-)pensioen gaat, terwijl $59 \%$ van de bedrijven verwacht dat de vervanging van deze medewerkers probleemloos zal verlopen. In de regio West, waar naar verwachting ook meer personeel zal uitstromen, verwachtte zelfs ruim een kwart van de bedrijven veel problemen bij de vervanging van uitvoerend technisch personeel. Voor het ondersteunende personeel worden daarentegen vrijwel geen problemen verwacht.

Tabel 1.4

Verwachte problemen bij vervanging van werknemers die komende 5 jaar met (pré)pensioen gaan, 2004 (\% bedrijven)

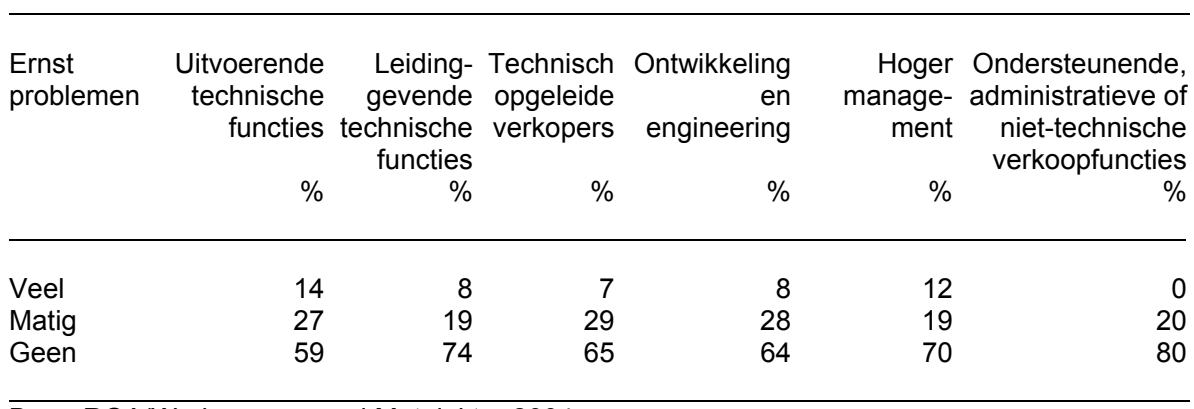

Bron: ROA/Werkgeverspanel Metalektro 2004

Wat wordt er nu gedaan om de problemen bij de vervanging van personeel dat met (pré-)pensioen gaat te lijf te gaan? Tabel 1.5 geeft daarvan, in volgorde van belangrijkheid, een overzicht. Bijna drie van de vier bedrijven geeft aan dat er nieuw personeel wordt aangenomen dat vervolgens in het bedrijf wordt opgeleid om vervangingsproblemen te voorkomen. Daarnaast geeft minstens de helft van de metalektrobedrijven aan dat het bestaande personeel wordt om- of bijgeschoold, dat 
er nieuwe, goed opgeleide werknemers worden aangenomen of dat door taakroulatie wordt geprobeerd het personeel breder inzetbaar te maken. In de volgende hoofdstukken zal er zowel aan scholing als brede inzetbaarheid van het personeel ruime aandacht besteed worden.

Tabel 1.5

Maatregelen om problemen met de vervanging van technisch personeel te beperken, 2004 (\% bedrijven)

Maatregelen

Aannemen werknemers en opleiden $\quad 74$

Om- en bijscholing van het personeel 58

Aannemen goede werknemers 56

Door taakroulatie werknemers breder inzetbaar maken $\quad 52$

Arbeidsbesparende technologie 36

Meer aandacht voor wervingsbeleid 30

Stimuleren carrièreplanning $\quad 25$

Productie naar het buitenland verplaatsen

Tijdelijke werving extra personeel 12

Meer personeel werven in het buitenland 11

Uitstel (pré-)pensioenleeftijd 4

Productie binnen Nederland verplaatsen 2

Noot: De verschillende percentages staan los van elkaar en hoeven dus niet op te tellen tot $100 \%$

Bron: $\quad$ ROA/Werkgeverspanel Metalektro 2004

Ongeveer één op de drie bedrijven probeert vervangingsproblemen te voorkomen door gebruik te maken van arbeidsbesparende technologie. Eenzelfde aantal doet dit door de aantrekkelijkheid van het bedrijf als werkgever te vergroten. Een vierde van de bedrijven probeert de carrièreplanning van de werknemers te stimuleren. Een minderheid van de bedrijven geeft aan de verwachte problemen te lijf te gaan door tijdelijk meer personeel te werven (12\%), (een gedeelte van) de productie naar het buitenland te verplaatsen (17\%), de productie (gedeeltelijk) binnen Nederland te verplaatsen $(2 \%)$, meer personeel te werven in het buitenland $(11 \%)$ of de (pré-) pensioenleeftijd uit te stellen (4\%). Als we deze cijfers vergelijken met de uitkomsten van de Arbeidsmarktmonitor Metalektro 2003, dan valt op dat een aantal reacties sterk in belang zijn toegenomen. Dit geldt vooral voor het aannemen van goed opgeleide werknemers (in 2003 door $36 \%$ van de bedrijven genoemd), de inzet van arbeidsbesparende technologie (in 2003 door 25\% genoemd, het breder inzetbaar maken van werknemers (in 2003 door 42\% genoemd) en last-but-not-least het verplaatsen van de productie naar het buitenland (in 2003 nog slechts door $4 \%$ van de bedrijven genoemd).

Ook uit de gesprekken met deelnemers aan het Werkgeverspanel kwam duidelijk naar voren dat de bedrijven proberen om problemen als gevolg van de vergrijzing van hun personeelsbestand te voorkomen. Veel bedrijven proberen hun werknemers zo lang mogelijk gezond en veilig aan het werk te houden door ze aan het eind van hun loopbaan andere taken te laten uitvoeren. Een personeelsfunctionaris van een bedrijf in de transportmiddelensector gaf bijvoorbeeld aan dat "het bedrijf er alles aan 
doet om de oudere werknemers zo lang als mogelijk binnenboord te houden". Dat kan op verschillende manieren. Omdat blijkt dat oudere werknemers vooral moeite hebben met het bijhouden van het productietempo worden ze vaak ingezet voor werk waarbij dat tempo minder van belang is. Ook geven sommige bedrijven hun oudere werknemers functies waarbij het leidinggeven en het coachen van jongere collega's centraal staat. Dit is van groot belang bij de opleiding van nieuw personeel. Een bedrijf gaf zelfs aan dat het deze manier van competentieverwerving veel efficiënter vindt dan het organiseren van een bepaald opleidingstraject. Een high-tech bedrijf benadrukt vooral het belang van mobiliteit van oudere werknemers: "Dat voorkomt dat mensen vast komen te zitten in hun huidige functie".

Een opmerkelijk initiatief van één van de bedrijven waarmee gesprekken gevoerd zijn is het gebruik van medische begeleiding op de werkvloer. Met enige trots vertelt de personeelsmanager dat er onlangs een fysiopreventieplan is gelanceerd: "We willen voorkomen dat mensen in de WAO of de ziektewet belanden en daarom komt er geregeld een fysiotherapeut op de werkvloer die de mensen uitlegt hoe ze hun fysieke capaciteiten het best kunnen gebruiken. Dat voorkomt dat mensen onnodig verslijten".

\section{Vergrijzing in de Metalektro over 10 jaar}

Hoe zit het met de vergrijzing in de Metalektro op de wat langere termijn? Om hierop een antwoord te kunnen geven, hebben we gekeken naar de cijfers van het Pensioenfonds Metalektro (PME). Deze cijfers geven een beeld van de leeftijdsopbouw van het huidige personeel in de Metalektro. Figuur 1.1 geeft daarvan, voor mannen en vrouwen afzonderlijk, een overzicht.

De figuur laat duidelijk zien dat het personeelsbestand in de Metalektro sterk vergrijsd is. Slechts $3 \%$ van het personeel is 25 jaar of jonger. Maar liefst $43 \%$ van het personeel is ouder dan 45 jaar. De 56+'ers die momenteel in de sector werkzaam zijn zullen de komende 10 jaar ongetwijfeld de arbeidsmarkt gaan verlaten. Dit is in totaal $15 \%$ van het huidige personeel. Daaronder zit echter een grote groep van $51-$ 55 jarigen, waarvan waarschijnlijk over 10 jaar ook een groot deel niet meer in de Metalektro aan het werk is. De totale arbeidsmarktuitstroom vanwege (pré-) pensionering in de komende 10 jaar zal daardoor ergens tussen de 15 en $28 \%$ van het huidige personeel bedragen. Hoewel vanwege een krimpende werkgelegenheid waarschijnlijk niet alle plaatsen zullen worden opgevuld, zal dit voor bepaalde metalektrobedrijven toch problemen opleveren. Voor bedrijven waarin de ervaring van het oudere personeel erg belangrijk is in het productieproces, betekent de grote uitstroom vanwege (pré-)pensionering immers dat een belangrijk deel van de ervaringskennis die jarenlang is opgebouwd verloren zal gaan. Overigens blijkt uit de figuur dat de vergrijzing bij de vrouwelijke werknemers iets minder speelt dan bij mannelijke werknemers.

Uit gesprekken met enkele deelnemers in de Metalektro blijkt dat de meeste bedrijven zich bewust zijn van de toenemende vergrijzing van het personeelsbestand en dat ze beseffen dat dit vereist dat er in de kennis en vaardigheden van het 
personeel wordt geïnvesteerd. In sommige bedrijven is er sprake van een erg hoge gemiddelde leeftijd van het personeel (45 jaar of ouder). Men verwacht in het algemeen ook dat de meeste werknemers die nu 51-55 jaar zijn over tien jaar niet meer werkzaam zullen zijn in de Metalektro. Slechts weinig bedrijven verwachten echter ook op wat langere termijn onoverkomelijke problemen vanwege de toekomstige uitstroom van ouder personeel. Bij sommige bedrijven verwacht men helemaal geen problemen doordat het personeel niet vervangen wordt; bij andere ondernemingen verwacht men in de toekomst meer gebruik te gaan maken van tijdelijk ingehuurd personeel.

Figuur 1.1

Leeftijdsopbouw van het personeelsbestand in de Metalektro, 2004

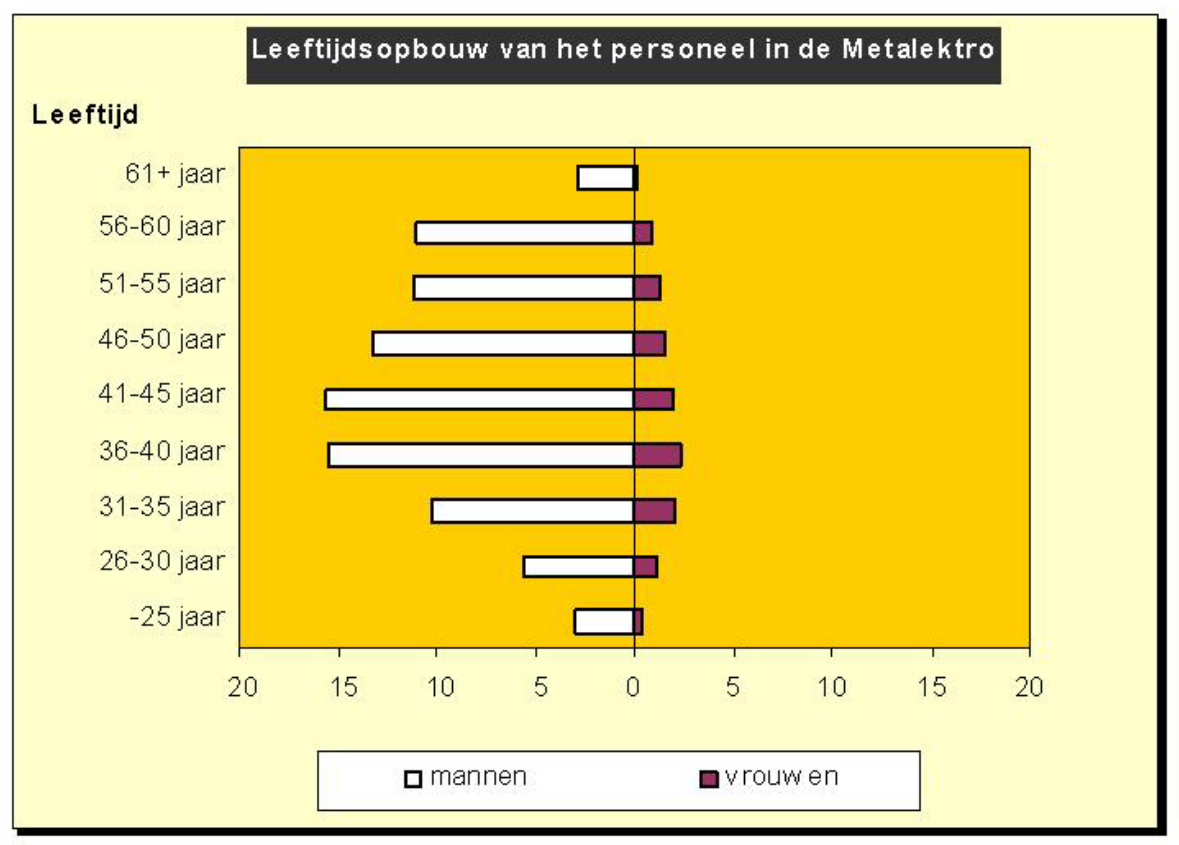

Bron: Pensioenfonds Metalektro 2005

\subsection{Innovaties}

Innovatie is in de Metalektro van levensbelang. Het pro-actief kunnen inspelen op veranderingen die de markt vraagt en het behoud van het concurrentievermogen vereist dat de metalektrobedrijven voortdurend investeren in het ontwikkelen van nieuwe producten en productieprocessen. Een personeelsfunctionaris van een groot high-tech bedrijf: "We zijn altijd driftig op zoek naar nieuwe producten en de daarbij behorende diensten". Een bedrijf dat grote installaties bouwt ziet een uitdaging in het "hoofd boven het water houden door slimmer te gaan bouwen".

Interessant is de vraag wat volgens de metalektrobedrijven de levensduur is van hun huidige technologie. Zoals tabel 1.6 laat zien denkt circa een derde van de bedrijven 
in de Nederlandse bedrijven dat de technologie die ze gebruiken nog langer dan vijf jaar meegaat. In de transportmiddelenindustrie is dat bij slechts $22 \%$ van de bedrijven het geval. Met andere woorden: De technologische dynamiek in de Metalektro is zeer groot. Over 5 jaar wordt in het overgrote deel van de bedrijven met een andere technologie gewerkt dan momenteel wordt gebruikt. Aangenomen mag worden dat dit belangrijke consequenties zal hebben voor de vereiste competenties en de inzetbaarheid van het personeel.

Tabel 1.6 laat ook zien dat verbeterde producten in de Nederlandse industrie bij $15 \%$ van de bedrijven in het algemeen meer dan 5 jaar mee gaan. In de Metalektro ligt dit percentage voor bijna alle sectoren hoger. In de basismetaal geldt dit zelfs voor $34 \%$ van de bedrijven. Alleen in de machine-industrie gaan productverbeteringen veel minder lang mee. Ook de geheel nieuwe producten gaan in de Metalektro vaker langer dan 5 jaar mee dan in andere industriële sectoren zoals bijvoorbeeld de chemie of de voedingsindustrie. Met name in de basismetaal hebben veel nieuwe producten een langere levensduur.

Tabel 1.6

Levensduur van technologie, verbeterde producten en nieuwe producten (\% bedrijven)

\begin{tabular}{lrrr}
\hline Sector & $\begin{array}{r}\text { Huidige technologie } \\
\text { gaat langer dan vijf } \\
\text { jaar mee }\end{array}$ & $\begin{array}{r}\text { Verbeterde } \\
\text { producten gaan } \\
\text { langer dan } \\
\text { vijf jaar mee }\end{array}$ & $\begin{array}{r}\text { Nieuwe producten } \\
\text { gaan langer dan vijf } \\
\text { jaar mee }\end{array}$ \\
& $\%$ & $\%$ & $\%$ \\
\hline Gehele Nederlandse industrie & & & 20 \\
Basismetaal & 30 & 34 & 45 \\
Metaalproducten & 31 & 19 & 23 \\
Machine industrie & 30 & 10 & 17 \\
Elektrotechniek & 27 & 22 & 30 \\
Transportmiddelen & 38 & 23 & 25
\end{tabular}

Noot: Aangezien het CBS een bredere definitie van de Metalektro hanteert, kunnen de gegevens enigszins vertekend zijn.

Bron: Innovatie-enquête CBS 2000-2002

Dat de houdbaarheid van veel productieprocessen en producten en diensten beperkt is, betekent dat metalektrobedrijven veel aandacht moeten besteden aan innovatie. Uit figuur 1.2 blijkt dat dit voor de bedrijven in de Metalektrobedrijven duidelijk het geval is. In de basismetaalindustrie en de machine-industrie vinden er zelfs in meer dan de helft van de bedrijven innovaties plaats. In de transportmiddelenindustrie en in de metaalproducten ligt de innovatiegraad op een wat lager niveau.

Gaat het nu bij de metalektrobedrijven vooral om product- of procesinnovatie? Figuur 1.3 laat zien dat het om een combinatie gaat, al domineren daarbij de procesinnovaties. Toch zijn er wel enkele kleine verschillen tussen de metalektrosectoren. In de basismetaal en de metaalproductenindustrie gaat het vaker om productinnovaties. In de elektrotechniek en de transportmiddelenindustrie wordt er daarentegen relatief veel aan procesinnovatie gedaan. 
Figuur 1.2

Percentage bedrijven met innovatie

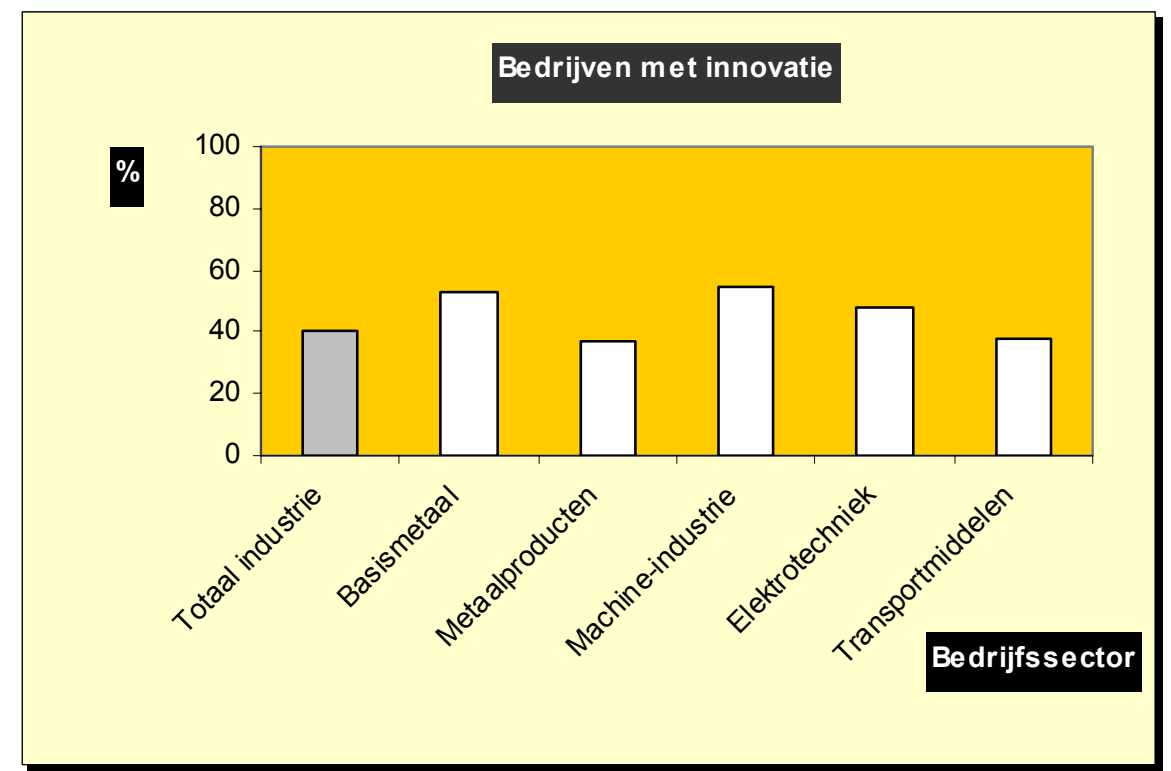

Noot: Aangezien het CBS een bredere definitie van de Metalektro hanteert, kunnen de gegevens enigszins vertekend zijn.

Bron: Innovatie-enquête CBS 2000-2002

Figuur 1.3

Product en procesinnovaties bij innoverende bedrijven

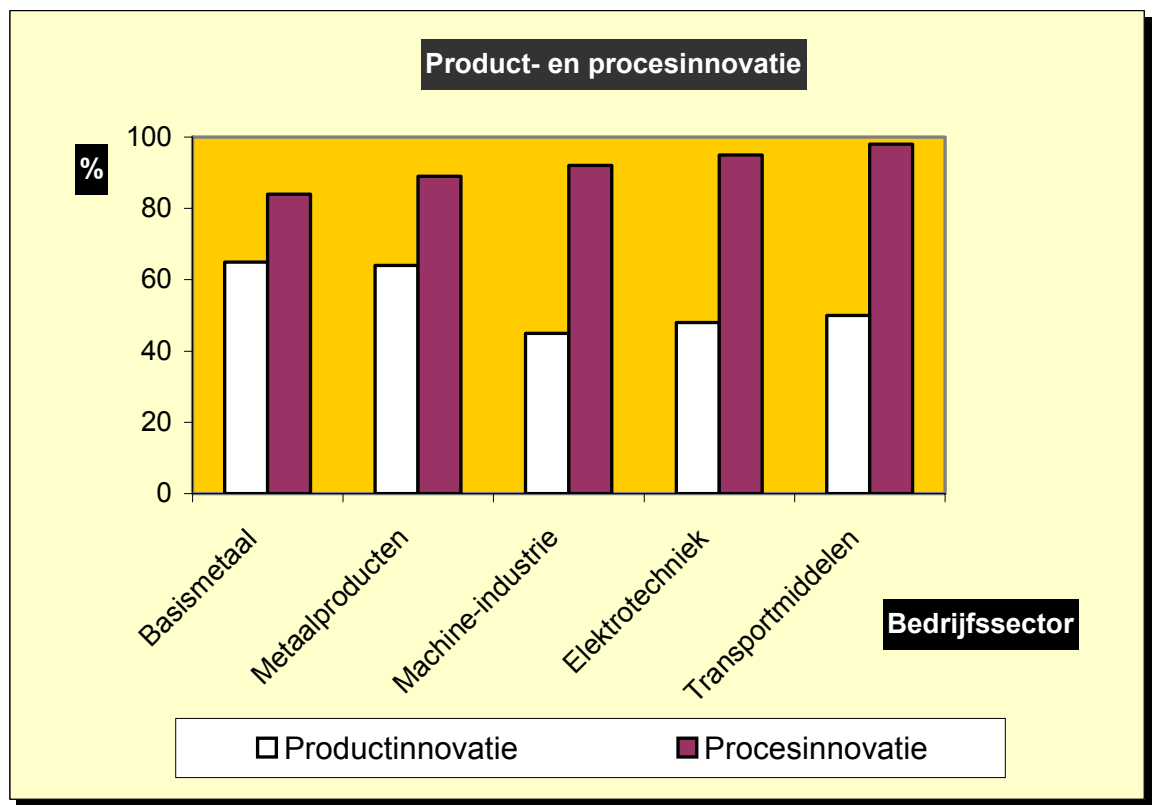

Noot: Aangezien het CBS een bredere definitie van de Metalektro hanteert, kunnen de gegevens enigszins vertekend zijn.

Bron: Innovatie-enquête CBS 2000-2002 
Uit achterliggende gegevens blijkt dat een productinnovatie meestal in het eigen bedrijf wordt ontwikkeld. Bij procesinnovatie gebeurt dat in het algemeen vaker buiten het bedrijf. Alleen in de machine-industrie en de elektrotechnische industrie worden de nieuwe productieprocessen voornamelijk binnen het bedrijf zelf ontwikkeld.

Innovatie is lang niet altijd een proces dat alleen door het bedrijf zelf wordt uitgevoerd. In gemiddeld één op de drie bedrijven in de Nederlandse industrie wordt er met andere partijen samengewerkt. Zoals tabel 1.7 laat zien ligt dat aandeel in de Metalektro, met uitzondering van de metaalproductenindustrie, nog wat hoger. De bedrijven in de basismetaalindustrie werken bij hun innovaties relatief vaak samen met afnemers en consultants, maar ook met hun concurrenten. In de machineindustrie wordt er relatief vaak met partners van binnen het eigen concern samengewerkt. De transportmiddelenindustrie werkt relatief veel samen met leveranciers, universiteiten en de (semi-) overheid.

Tabel 1.7

Samenwerking in verband met innovaties (\% bedrijven)

\begin{tabular}{|c|c|c|c|c|c|c|}
\hline & $\begin{array}{r}\text { Gehele } \\
\text { Nederlandse } \\
\text { industrie } \\
\%\end{array}$ & $\begin{array}{r}\text { Basis- } \\
\text { metaal } \\
\%\end{array}$ & $\begin{array}{r}\text { Metaal- } \\
\text { producten } \\
\%\end{array}$ & $\begin{array}{r}\text { Machine- } \\
\text { industrie } \\
\%\end{array}$ & $\begin{array}{r}\text { Elektro- } \\
\text { Techniek } \\
\%\end{array}$ & $\begin{array}{l}\text { Transport- } \\
\text { middelen }\end{array}$ \\
\hline Samenwerking & 33 & 52 & 20 & 41 & 53 & 37 \\
\hline \multicolumn{7}{|l|}{ Samenwerking met: } \\
\hline Eigen concern & 69 & 67 & 49 & 77 & 58 & 53 \\
\hline Afnemers & 60 & 87 & 68 & 53 & 53 & 41 \\
\hline Leveranciers & 69 & 68 & 58 & 67 & 62 & 79 \\
\hline Concurrenten & 35 & 44 & 42 & 27 & 29 & 19 \\
\hline Universiteiten & 42 & 44 & 39 & 36 & 44 & 53 \\
\hline (semi-)overheid & 44 & 40 & 46 & 32 & 40 & 50 \\
\hline Privaat onderzoek & 30 & 31 & 28 & 27 & 29 & 22 \\
\hline Consultants & 40 & 64 & 37 & 39 & 38 & 29 \\
\hline
\end{tabular}

Noot: Aangezien het CBS een bredere definitie van de Metalektro hanteert, kunnen de gegevens enigszins vertekend zijn.

Bron: Innovatie-enquête CBS 2000-2002

Wat zijn de kosten van innovatie voor de Nederlandse metalektro-industrie? In de periode 2000-2002 werd er in de Nederlandse metalektro-industrie in totaal 2,95 miljard euro uitgegeven aan het ontwikkelen van innovaties (Innovatie enquête CBS, 2000-2002). Dat is meer dan de helft van het bedrag dat de gehele Nederlandse industrie aan innovatie uitgaf. Binnen de Metalektro besteedde vooral de elektrotechnische industrie relatief veel aan innovatie. Bedrijven in deze sector gaven gemiddeld zelfs meer dan $35 \%$ van hun toegevoegde waarde (productiewaardekosten) uit aan innovatie. In de machine-industrie bedroeg dit aandeel circa $14 \%$. In de metaalproductenindustrie werd daarentegen in de periode nog geen $4 \%$ van de toegevoegde waarde besteed aan innovatie. 
Vreemd genoeg beschikt de Nederlandse kenniseconomie niet over meer recente cijfers over het innovatiebeleid. Daarom hebben we in een aantal gesprekken met HRM-functionarissen van metalektrobedrijven gevraagd naar het belang van innovatie in hun bedrijf. De meeste bedrijven zien innovatie als een levensnoodzakelijk onderdeel van het bedrijfsproces. Het is een continu proces dat er toe leidt dat de producten steeds efficiënter gemaakt worden. In de metalektrobedrijven waarmee gesprekken gevoerd zijn gaat het bij innovatie vooral om procesinnovatie. Een personeelsmanager verwoordde het kort en krachtig: "Het is de uitdaging om effectiever en efficiënter om te gaan met bestaande componenten. Met standaardproducten is namelijk niet veel te verdienen; maar met een 'slimme' organisatie wel". Een ander bedrijf gaf aan dat de innovatie vooral betrekking heeft op het vervangen van oude door nieuwe machines, waarmee sneller en beter gewerkt kan worden en die in plaats van handmatig, computergestuurd bediend kunnen worden.

\section{Innovatie in het HRM-beleid}

Innovatie heeft natuurlijk niet alleen betrekking op technologische vernieuwingen. Naast het realiseren van product- of procesinnovatie zullen bedrijven ook door middel van hun personeelsbeleid innovatief te werk moeten gaan. Om te kijken welke trends zich op dit vlak voordoen wordt er in tabel 1.8 een overzicht gegeven van de mate waarin metalektrobedrijven de afgelopen jaren gebruik hebben gemaakt van bepaalde HRM-instrumenten. Uit de tabel komt duidelijk naar voren dat het HRMbeleid in de Metalektro steeds meer aandacht krijgt. Het overgrote deel van de bedrijven biedt hun technisch personeel opleidingsfaciliteiten aan. Ook hebben de meeste bedrijven een bedrijfsopleidingsplan (BOP). Het gebruik van een BOP is de laatste jaren bovendien duidelijk toegenomen. Uit gesprekken met deelnemende bedrijven kwam naar voren dat het hebben van een BOP gezien wordt als een aanvulling op het aanbieden van scholingsmogelijkheden aan het personeel. Een personeelsfunctionaris omschreef het BOP in haar bedrijf als een "soort planningsdocument. Dit planningsdocument maakt het ook mogelijk om de mogelijkheden die ESF-subsidies bieden, volledig te kunnen benutten".

Het gebruik van het persoonlijk ontwikkelingsplan (POP) is nog beperkt. Wel is er de laatste paar jaar sprake van een lichte stijging van het aantal bedrijven dat dit instrument gebruikt. Het gebruik van een competentiematrix is de afgelopen jaren daarentegen ongeveer gelijk gebleven.

Tabel 1.8 laat verder zien dat steeds meer bedrijven ertoe overgaan de verworven competenties van hun personeel door middel van een EVC-traject te (laten) erkennen. Momenteel maakt $10 \%$ van de bedrijven gebruik van dit HRM-instrument. Een veel grotere groep bedrijven (25\%) ziet EVC als een van de speerpunten van hun toekomstig HRM-beleid (zie hoofdstuk 6). Hoewel momenteel nog relatief weinig bedrijven loopbaan- of carrièreplanning gebruiken, zien we dat dit HRM-instrument wel duidelijk in de lift zit. In 2002 gebruikte nog slechts in $8 \%$ van de bedrijven dit; in 2004 is dit toegenomen tot $23 \%$ van de bedrijven. Bovendien is het aantal bedrijven dat gebruik maakt van functieroulatie bijna verdubbeld: circa de helft van de metalektro maakte er in 2004 al gebruik van. Ook het aantal bedrijven dat scholingsgesprekken voert is de afgelopen jaren gestaag gegroeid: van $45 \%$ in 2002 tot $63 \%$ 
in 2004. Daarnaast voeren steeds meer bedrijven de laatste paar jaar functioneringsen beoordelingsgesprekken, maar hier zijn de stijgingen minder spectaculair.

Tabel 1.8

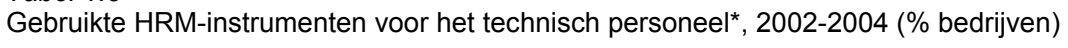

\begin{tabular}{lccc}
\hline HRM-instrument & $\begin{array}{c}2002 \\
\%\end{array}$ & $\begin{array}{c}2003 \\
\%\end{array}$ & $\begin{array}{c}2004 \\
\%\end{array}$ \\
\hline Scholing en competenties & & & \\
Opleidingsfaciliteiten & 91 & 80 & 83 \\
Bedrijfopleidingenplan (BOP) & 69 & 68 & 79 \\
Persoonlijk Ontwikkelingsplan (POP) & 27 & 26 & 30 \\
Competentiematrix & 38 & 32 & 37 \\
Erkenning Verworven Competenties (EVC) & 7 & 9 & 10 \\
& & & \\
Mobiliteit & 8 & 7 & 23 \\
Loopbaan/carriereplanning & 25 & 28 & 48 \\
Functieroulatie & 1 & 2 & 6 \\
Loopbaanadvies/mobiliteitscentrum & & & \\
Communicatie & 80 & 83 & 90 \\
Functioneringsgesprekken & 71 & 77 & 79 \\
Beoordelingsgesprekken & 45 & 54 & 63 \\
Scholingsgesprekken & 91 & 85 & 84 \\
Geregeld werkoverleg & & & \\
& &
\end{tabular}

Bron: ROA/Werkgeverspanel Metalektro 2002, 2003, 2004

*: Hierbij is alleen gekeken naar de instrumenten die voor een meerderheid van het technisch personeel worden ingezet.

Het is opmerkelijk dat het percentage bedrijven dat geregeld werkoverleg voert de laatste jaren enigszins gedaald is. Toch zetten nog steeds meer dan acht van de tien bedrijven dit instrument in. Een bedrijf gaf aan dat ze de trend van minder werkoverleg niet herkent, maar dat ze in de toekomst wel streven naar minder werkoverleg, omdat men vindt dat er momenteel teveel onnodige communicatie plaatsvindt. Het bedrijf benadrukt daarbij de essentiële rol van goed opgeleid personeel: "Je moet wel met goede mensen om de tafel zitten om iets nuttigs met werkoverleg te bereiken”. Ten slotte zijn er nog steeds maar weinig bedrijven met een loopbaanadvies of mobiliteitscentrum, maar er is ook hier sprake van een stijgende trend. Had in 2002 nog slechts $1 \%$ van de bedrijven een dergelijk centrum, in 2004 was dit aandeel gestegen tot $6 \%$. Overigens is dit natuurlijk een HRMinstrument dat alleen voor grotere bedrijven is weggelegd.

De meeste bedrijven waarmee aanvullende gesprekken werden gevoerd herkennen de trends in het HRM-beleid dat er in de Metalektro gevoerd wordt. Toch zien ze ook andere ontwikkelingen die specifiek zijn voor hun eigen bedrijf. Zo geeft een HRMfunctionaris van een transportmiddelenbedrijf aan dat er de laatste jaren ook bijzonder veel aandacht is gekomen voor de employability van het personeel. Daaronder verstaat men "het vermogen van het personeel om zich te kunnen handhaven op de arbeidsmarkt wanneer de huidige baan wegvalt". Een ander bedrijf heeft het over multi-inzetbaarheid en loopbaankansen: "We proberen hiervoor interesse te kweken door de werknemers actief te betrekken bij de planning en de 
verbetering van de productieprocessen en door de verantwoordelijkheden en beslissingsbevoegdheid zoveel mogelijk op de lagere niveaus te leggen". Dat blijkt in de praktijk niet altijd even makkelijk te zijn: Vooral het wat oudere personeel is niet altijd bereid om zich flexibel op te stellen. De personeelsmanager van het bedrijf omschrijft dit als een "laat mij maar lekker lassen"-mentaliteit.

\section{Competentiemanagement}

Eén van de opmerkelijke zaken in de innovatie van het HRM-beleid betreft competentiemanagement. Hiervan is sprake wanneer er binnen een bedrijf sprake is van een expliciet beleid dat zich richt op de ontwikkeling en de optimale inzet van de competenties van het personeel. Tabel 1.9 laat zien dat één op de vier bedrijven gebruik maakt van competentiemanagement. Dat wil overigens niet zeggen dat er in driekwart van de bedrijven geen aandacht is voor de competenties van het personeel, maar wel dat in deze bedrijven minder sprake is van een expliciet competentie-gerichte benadering in het HRM-beleid. In de regio Zuid zetten relatief weinig bedrijven (20\%) competentiemanagement in. In de regio Noord/Oost wordt het daarentegen al vaker toegepast dan in de andere regio's: In deze regio is er bij bijna één op de drie bedrijven al sprake van competentiemanagement.

Tabel 1.9

Gebruik van competentiemanagement, 2004 (\% bedrijven)

Gebruik competentiemanagement

$\mathrm{Ja}$

Gebruikers van competentiemanagement met een geautomatiseerd systeem

$\mathrm{Ja}$

Nee

Bron: ROA/Werkgeverspanel Metalektro 2004

Overigens werkt slechts $15 \%$ van de bedrijven die gebruik maken van competentiemanagement met een geautomatiseerd systeem. De meerderheid van de bedrijven werkt daarentegen met andere, niet-geautomatiseerde systemen.

Uit de gesprekken met deelnemers aan het panel blijkt dat er duidelijk meer zit achter de cijfers van tabel 1.9. Allereerst zijn er bedrijven die geen competentiemanagement gebruiken, maar wel iets dat daar sterk op lijkt. Een groot bedrijf zegt bijvoorbeeld niet te werken met competentiemanagement maar wel met gedragscriteria: "Het begrip competentie is een hype. Overstappen van gedragscriteria naar competenties zou voor ons bedrijf veel te veel kosten met zich meebrengen en is ook niet nodig. We kunnen die energie beter steken in het maken van winst". Bij een ander bedrijf is men onlangs begonnen met competentiemanagement maar wordt het, omdat de directie van het bedrijf niet overtuigd is van het nut ervan, niet voortgezet. De 
personeelsfunctionaris vind het erg jammer dat de volgende stap, "het linken van de competenties aan de opleidingsbehoeften", niet door gaat. "In ons bedrijf is het management helaas nog teveel gericht op de techniek en te weinig op de menselijke kant", aldus de HRM-functionaris.

Twee andere bedrijven waarmee gesprekken zijn gevoerd, zijn daarentegen erg enthousiast over competentiemanagement. Een personeelsmanager van een constructiebedrijf: "Al ons technisch personeel wordt reeds op competenties beoordeeld en dit jaar zijn we bezig met de ontwikkeling van een competentiesysteem voor de hogere functies". De manager vindt competentiemanagement een prima managementtool: "het stelt ons in staat bepaalde fenomenen eens vanuit een ander perspectief te bekijken en het brengt gewoon meer 'swung' in de organisatie. Binnenkort gaan we het hele systeem automatiseren in samenwerking met andere vestigingen van het concern". Een ander bedrijf ziet het gebruik van competentiemanagement als een absolute prioriteit: "We gebruiken competentiemanagement nu nog vooral op papier, in functiebeschrijvingen en personeelsdossiers, maar in 2005 gaan we het competentiemanagement ook helemaal automatiseren".

\subsection{Internationalisering}

De Nederlandse Metalektro is een sterk internationaal geörienteerde bedrijfssector. Dat blijkt bijvoorbeeld uit het feit dat meer dan de helft van de productie wordt geëxporteerd (volgens Orgalime, de Europese werkgeversvereniging voor de technische industrie 2002). Naast de traditionele sterke exportgerichtheid van de sector is er de laatste jaren ook steeds duidelijker sprake van een internationalisering van de arbeidsmarkt. Op dit punt zijn er voor metalektrobedrijven momenteel twee belangrijke opties: de werving van personeel in het buitenland en de verplaatsing van activiteiten naar het buitenland.

\section{Werven in het buitenland}

Tabel 1.10 laat zien dat de grote meerderheid van de bedrijven in de Metalektro (85\%) geen technisch personeel in het buitenland werft. Bij $13 \%$ van de bedrijven wordt er soms personeel in het buitenland geworven, terwijl slechts $2 \%$ van de bedrijven regelmatig buitenlands personeel werft. Uit tabel 1.11 blijkt dat wanneer er personeel in het buitenland wordt geworven, dit meestal technici vanuit een ander EU land betreft. Minder dan een derde van de bedrijven die in het buitenland werven geeft aan dat er zowel in de EU als daarbuiten personeel wordt geworven.

Tabel 1.10

Werven van technisch personeel in het buitenland, 2004 (\% bedrijven)

Werven technisch personeel in het buitenland 
Tabel 1.11

Regio van waaruit er in het buitenland technisch personeel wordt geworven, 2004 (\% bedrijven)

Regio vanuit waar er technisch personeel geworven wordt

Hoofdzakelijk binnen de EU

Hoofdzakelijk buiten de EU

Zowel binnen als buiten de EU

Bron: ROA/Werkgeverspanel Metalektro 2004

Hoe wordt de aanstelling van buitenlands technisch personeel georganiseerd? Zoals figuur 1.4 laat zien gaat het meestal via een uitzend- of detacheringsbureau. In minder dan één op de drie bedrijven die buitenlands personeel werven wordt de aanstelling geregeld via een afdeling in het eigen bedrijf of via het moederbedrijf. In $5 \%$ van de bedrijven die buitenlands personeel werven gaat het om grensarbeid.

Figuur 1.4

Manier waarop de aanstelling van buitenlands technisch personeel wordt georganiseerd, 2004 (\% bedrijven)

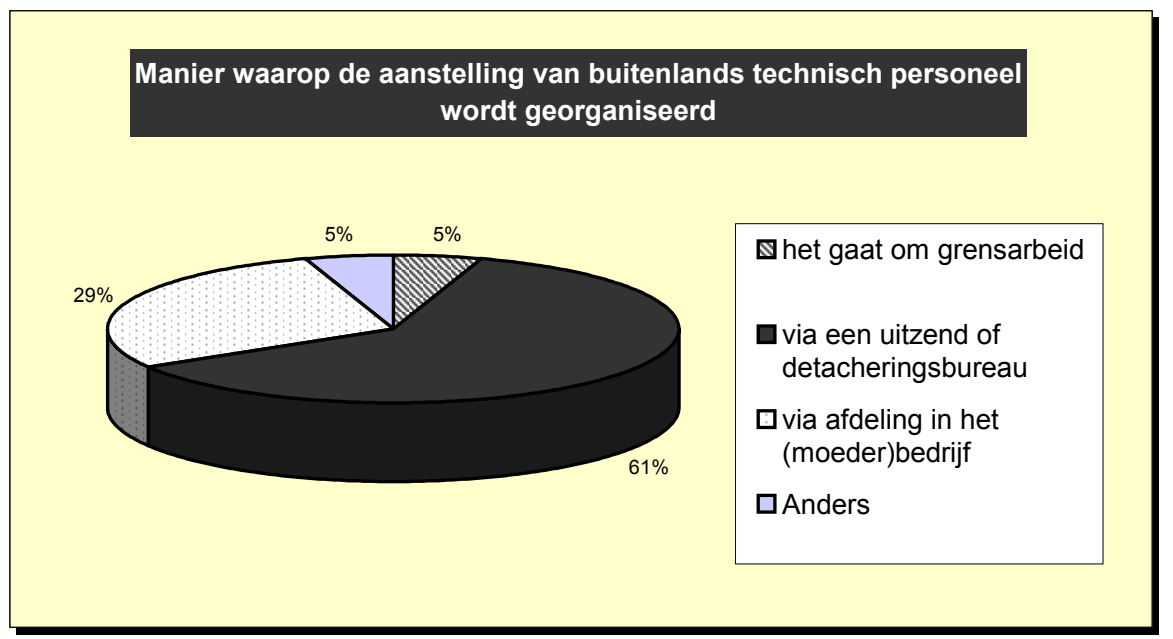

Bron: ROA/Werkgeverspanel Metalektro 2004

Dat veel bedrijven nu nog geen technisch personeel in het buitenland werven heeft er wellicht mee te maken dat daar op dit moment ook nog geen noodzaak toe bestaat. Daarom is er ook gevraagd wat bedrijven zouden doen als er knelpunten bij de werving van technisch personeel zouden optreden (zie tabel 1.12). Het blijkt dat in dat geval maar liefst bijna de helft van de bedrijven op zijn minst overweegt om personeel in het buitenland te werven. $15 \%$ van de bedrijven zegt dit zelfs zeker te gaan doen als er opnieuw knelpunten optreden bij de werving van technisch personeel op de Nederlandse arbeidsmarkt. 
Tabel 1.12

Werven in het buitenland bij knelpunten voor technisch personeel, 2004 (\% bedrijven)

Werven in het buitenland

$\mathrm{Ja}$

Misschien

Nee

Weet niet/geen mening

Bron: ROA/Werkgeverspanel Metalektro 2004

\section{Verplaatsing naar het buitenland}

De globalisering van afzetmarkten en de beschikbaarheid van goedkoper personeel buiten Nederland zou voor bedrijven in de Metalektro een reden kunnen zijn om zich te verplaatsen naar het buitenland. Toch blijken verreweg de meeste bedrijven er de voorkeur aan te geven om in Nederland te blijven produceren (zie ook: FME/CWM, verplaatsing productiefaciliteiten naar centraal- en Oost-Europa, een versnellend proces, 2003). Toen er in 2003 gevraagd werd naar de redenen waarom men in Nederland blijft, werd daarop vaak geantwoord dat de nabijheid van afzetmarkten en het goede niveau van het technische personeel in Nederland daarvoor de belangrijkste redenen zijn. Uit recente gesprekken die met een aantal deelnemers aan het Werkgeverspanel gehouden zijn blijkt dat vooral het argument van het goede niveau van de Nederlandse werknemers steeds minder relevant wordt. Veel bedrijven realiseren zich dat goed opgeleid technisch personeel ook in veel andere landen (bijvoorbeeld in landen in Oost-Europa) voldoende beschikbaar is. Een bedrijf dat momenteel sterke concurrentie ondervindt gaf te kennen dat het ook "slechts een kwestie van tijd is voordat het personeel in het buitenland op hetzelfde niveau is" en dat "de kwaliteit van het Nederlandse personeel helemaal niet zo goed is", omdat er belangrijke competentietekorten zijn bij nieuwe werknemers die van de scholen afkomen.

De nabijheid van afzetmarkten als argument om in Nederland te blijven produceren blijkt vooral voor de grote bedrijven waarmee gesprekken werden gevoerd van groot belang te zijn. Zo geeft een bedrijf uit de transportmiddelenindustrie aan dat ze onderdeel uitmaakt van een wereldwijd concern dat de markt geografisch heeft verdeeld, waarbij het Nederlandse bedrijf zich beperkt tot de Europese markt. Voor kleine bedrijven kan de situatie anders zijn. Zo stelde een wat kleiner bedrijf dat "onder invloed van de internationalisering het voordeel van dicht bij de afzetmarkt zitten steeds minder relevant wordt".

Wat is dan wel de reden om in Nederland te blijven produceren? Meerdere bedrijven gaven aan dat ze een sterk verantwoordelijkheidsgevoel voelen voor de werkgelegenheid van hun personeel. Een bedrijf stelde dat "de vaste werknemers op een economisch verantwoorde wijze aan het werk moeten worden gehouden". Andere bedrijven benadrukken de kwaliteit van hun producten. Zo gaven veel bedrijven bijvoorbeeld aan dat ze zich niet primair richten op massaproductie tegen een zo laag mogelijke prijs, maar dat ze "een goed Nederlands bedrijf willen zijn" en dat ze 
zich "vooral willen profileren als een bedrijf met een degelijke reputatie door te zorgen voor topkwaliteit en optimale levertijden".

Ook blijkt dat bedrijven, hoewel ze de productie zélf niet naar het buitenland verplaatsen, al wel veel samenwerken met partners in het buitenland. Een high-tech bedrijf stelde dat "de Nederlandse Metalektro erg goed is in het verkopen, de dienstverlening en de ontwikkeling van nieuwe producten, maar dat de productie van standaardcomponenten in het buitenland vaak veel goedkoper kan". De samenwerking met andere bedrijven in lagelonenlanden blijkt vaak erg goed te verlopen, vooral wanneer het gaat om bedrijven die behoren tot hetzelfde concern en wanneer er sprake is van een verdeling van verantwoordelijkheden: de westerse bedrijven ontwikkelen en innoveren, terwijl de bedrijven in de lagelonenlanden zich toeleggen op een zo efficiënt mogelijke productie van componenten. 



\section{De structuur van de krimpende werkgelegenheid}

In dit hoofdstuk kijken we meer in detail naar de werkgelegenheidsontwikkelingen in 2004 en de structuur van de werkgelegenheid in de Metalektro. Evenals in vorige jaren was er ook in 2004 sprake van een teruglopende werkgelegenheid. Maar hoe ziet de structuur van de werkgelegenheid er uit? Er zal achtereenvolgens worden ingegaan op persoonskenmerken, het opleidingsniveau van de werkenden en de aard van het dienstverband. We eindigen het hoofdstuk met een overzicht van de mate waarin er in de Metalektro gebruik gemaakt wordt van personeel dat wel werkzaam is in de sector, maar niet in dienst is van de bedrijven zelf.

\subsection{De werkgelegenheid blijft krimpen}

Ook in 2004 bleef de werkgelegenheid in de Metalektro krimpen. In de arbeidsmarktmonitor is bij iedere meting gevraagd naar de werkgelegenheidsontwikkeling van de afgelopen vier maanden. Tabel 2.1 geeft per functiecategorie een overzicht van het percentage bedrijven dat te maken had met een krimpende werkgelegenheid. Het blijkt dat er telkens in circa één op de drie bedrijven sprake was van een krimpende werkgelegenheid voor het uitvoerend technisch personeel. Ook voor ondersteunend, administratief of niet-technisch verkooppersoneel gaf bijna drie van de tien bedrijven aan dat de werkgelegenheid terugloopt.

Tabel 2.1

Krimpende werkgelegenheid, naar functiecategorie, 2004 (\% bedrijven)

\begin{tabular}{|c|c|c|c|}
\hline \multirow[t]{2}{*}{ Functiecategorie } & \multirow{2}{*}{$\begin{array}{r}\text { Januari- } \\
\text { april } \\
\%\end{array}$} & \multirow{2}{*}{$\begin{array}{r}\text { Mei- } \\
\text { augustus } \\
\%\end{array}$} & \multirow{2}{*}{$\begin{array}{r}\text { September- } \\
\text { december } \\
\%\end{array}$} \\
\hline & & & \\
\hline Uitvoerende technische functies & 39 & 28 & 31 \\
\hline Leidinggevende technische functies & 24 & 16 & 18 \\
\hline Technisch opgeleide verkopers & * & 3 & 9 \\
\hline Ontwikkeling en engineering & 19 & 13 & 12 \\
\hline (Hoger) management & 11 & 10 & 15 \\
\hline $\begin{array}{l}\text { Ondersteunend, administratief of niet-technisch } \\
\text { verkooppersoneel }\end{array}$ & 35 & 28 & 25 \\
\hline $\begin{array}{ll}\text { Noot: } & \text { De verschillende percentages staan los } \\
& 100 \% . \\
& \text { *: Niet beschikbaar }\end{array}$ & en hoever & dus niet $\mathrm{o}$ & \\
\hline Bron: $\quad$ ROA/Werkgeverspanel Metalektro 2004 & & & \\
\hline
\end{tabular}

Relatief weinig bedrijven hadden in 2004 een krimpende werkgelegenheid voor managementfuncties. Opmerkelijk is ook dat er vrijwel geen bedrijven waren waar de werkgelegenheid voor technisch opgeleide verkopers afnam. Uit achterliggende cijfers blijken de verschillen in werkgelegenheidskrimp tussen de verschillende regio's gering. Wel valt het op dat er in de regio Zuid bij wat meer bedrijven sprake is van werkgelegenheidskrimp dan in de andere regio's. De sterk uiteenlopende 
krimpcijfers voor de verschillende functiecategorieën illustreren dat de krimp van de totale werkgelegenheid in de Metalektro gepaard gaat met aanzienlijke verschuivingen in de functiestructuur.

\section{Gevolgen van de krimpende werkgelegenheid}

Wat zijn nu de gevolgen van de krimpende werkgelegenheid? Tabel 2.2 laat zien dat in ruim de helft van de bedrijven met een krimpende werkgelegenheid in de technische functies er sprake is van een vacaturestop. In meer dan vier van de tien bedrijven worden werknemers bij een krimpende werkgelegenheid nog altijd gestimuleerd om eerder met (pré-)pensioen te gaan. Circa $45 \%$ van de bedrijven verplaatst technisch personeel naar andere functies in het bedrijf, terwijl gemiddeld $40 \%$ van de bedrijven tijdelijke contracten niet verlengt. Twee op tien bedrijven met krimpende werkgelegenheid stimuleert hun technisch personeel om op zoek te gaan naar een andere baan.

Tabel 2.2

Gevolgen van de krimpende werkgelegenheid voor technische werknemers, 2004 (\% bedrijven)

\begin{tabular}{|c|c|c|c|}
\hline Gevolg & $\begin{array}{r}\text { Januari- } \\
\text { april }\end{array}$ & $\begin{array}{r}\text { Mei- } \\
\text { augustus }\end{array}$ & $\begin{array}{r}\text { September- } \\
\text { december }\end{array}$ \\
\hline & $\%$ & $\%$ & $\%$ \\
\hline Vacaturestop & 62 & 79 & 52 \\
\hline Tijdelijke contracten worden niet verlengd & 46 & 60 & 34 \\
\hline $\begin{array}{l}\text { Werknemers worden naar andere functies binnen het } \\
\text { bedrijf overgeplaatst }\end{array}$ & 39 & 43 & 39 \\
\hline $\begin{array}{l}\text { Werknemers worden gestimuleerd om eerder van } \\
\text { (pré-) pensioen gebruik te maken }\end{array}$ & 50 & 41 & 45 \\
\hline $\begin{array}{l}\text { Werknemers worden gestimuleerd om andere baan te } \\
\text { zoeken }\end{array}$ & 18 & 23 & 22 \\
\hline Gewilde werknemers verlaten bedrijf & 7 & 11 & 36 \\
\hline Gedwongen ontslagen & 37 & 30 & 25 \\
\hline Anders & 4 & 9 & 8 \\
\hline
\end{tabular}

Noot: De verschillende percentages staan los van elkaar en hoeven dus niet op te tellen tot $100 \%$.

Bron: ROA/Werkgeverspanel Metalektro 2004

Een zeer opmerkelijke uitkomst is dat gedurende 2004 steeds meer bedrijven aangaven dat de krimpende werkgelegenheid in hun bedrijf ook leidde tot het vertrek van werknemers, die het bedrijf graag in dienst had gehouden. De teruglopende werkgelegenheid in deze bedrijven heeft er kennelijk ook toe geleid dat goede werknemers op eigen initiatief hun heil elders zijn gaan zoeken. In de laatste vier maanden van 2004 was dat zelfs bij meer dan één derde van de bedrijven het geval. Tegelijkertijd was er in de loop van het jaar steeds minder sprake van gedwongen ontslag. Gedwongen ontslagen komen overigens het vaakst voor bij bedrijven in de regio Zuid. 


\section{$2.2 \quad$ Wie werkt waar?}

Hoe ziet de structuur van de werkgelegenheid er uit in de metalektrosector? Figuur 2.1 geeft allereerst een overzicht van de soorten functies van de werknemers bij de deelnemende bedrijven aan het Werkgeverspanel Metalektro. Daaruit blijkt dat het grootste gedeelte van het personeel een uitvoerende technische functie heeft. In totaal gaat het hier om $56 \%$ van het personeel. Op de tweede plaats komt het ondersteunend personeel, dat $18 \%$ van het personeel in de Metalektro uitmaakt. Ook het personeel dat betrokken is bij ontwikkeling en engineering neemt een belangrijke plaats in. Zo blijkt dat er gemiddeld genomen voor iedere vier personeelsleden met een uitvoerende technische functie iemand in dienst is waarbij ontwikkeling en engineering centraal staat. Dit onderstreept het sterk innovatieve karakter van de Metalektro. Ten slotte blijkt dat de leidinggevende technische functies en managementfuncties in de Metalektro in totaal 10\% uitmaken van de totale werkgelegenheid. Op de werkvloer is de verhouding leidinggevende-productiepersoneel circa één op zes.

\section{Figuur 2.1}

Werkgelegenheid naar functiecategorie, 2004

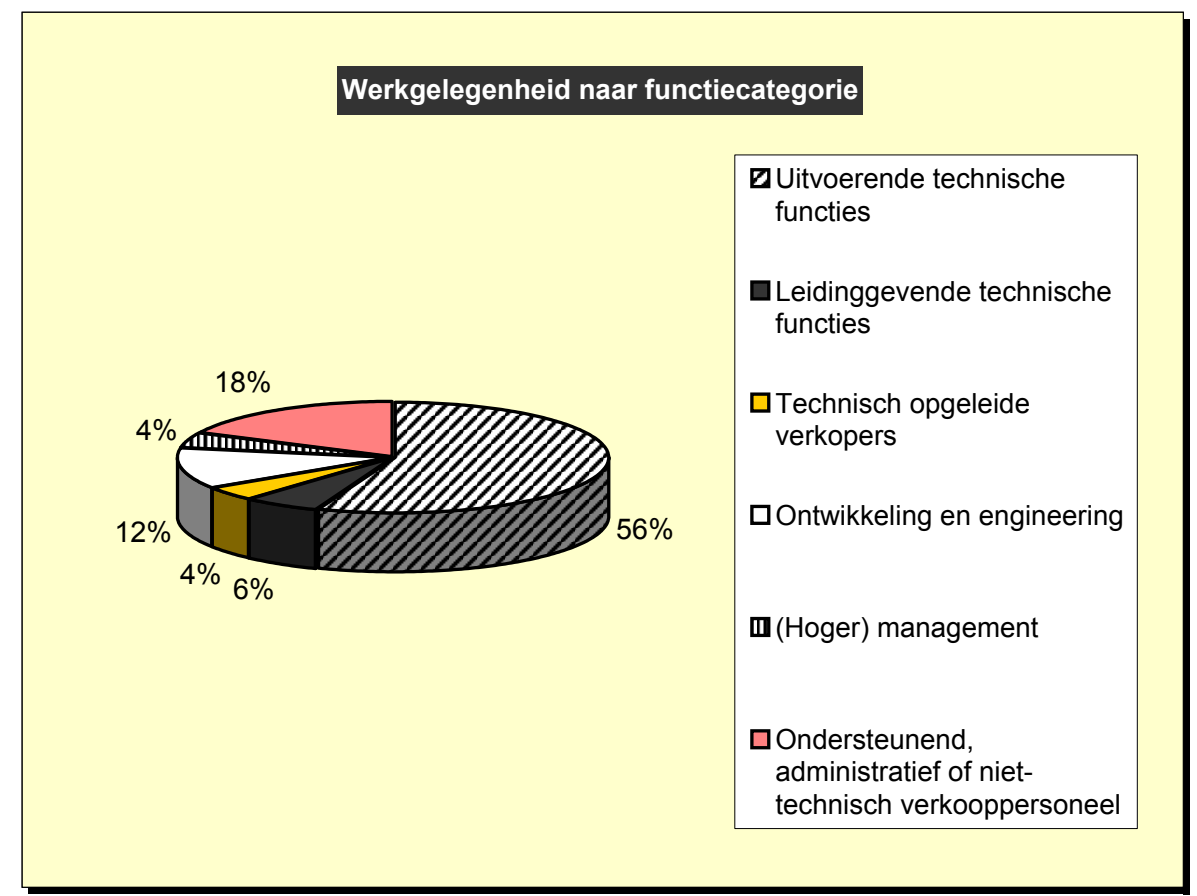

Bron: ROA/Werkgeverspanel Metalektro 2004

Om zicht te krijgen in hoeverre de verhouding tussen het leidinggevende technisch personeel en het uitvoerend technisch personeel verandert is hier ook in de gesprekken met deelnemers aan het Werkgeverspanel aandacht aan besteed. Opmerkelijk genoeg zien sommige bedrijven een tendens tot "afplatting" van de organisatie (minder leidinggevenden) terwijl er in andere bedrijven juist sprake is van 
een toename van de verhouding tussen leidinggevend en uitvoerend technisch personeel. Een HRM-manager van een high-tech bedrijf: "We zijn constant bezig met het platter maken van de organisatie, omdat we afwillen van het delegeren van verantwoordelijkheden naar lagere managementniveaus. Leidinggevenden op lager niveau hebben ook niet genoeg capaciteiten om effectief leiding te geven. Daarnaast speelt bij ons ook een kostenargument: veel leidinggevenden in dienst hebben is economisch gezien niet meer haalbaar". Dat laatste is ook het doorslaggevende argument voor een ander bedrijf: "Na een belangrijke teruggang in onze afzet is het aantal leidinggevenden ongeveer gehalveerd. We verwachten in de toekomst nog een verdere daling van het aantal leidinggevenden, omdat er nog teveel inefficiënte communicatie is tussen de verschillende afdelingen. We willen het bedrijf verder stroomlijnen en daarin past een afname van het aantal leidinggevenden".

Enkele andere metalektrobedrijven zien daarentegen helemaal geen tendens tot een verplatting van de organisatie. Een personeelsfunctionaris benadrukt dat er in zijn bedrijf juist sprake is van een groeiend aantal leidinggevende technische medewerkers: "Er is sprake van een trend waarin de leidinggevende steeds meer taken krijgt. Naast het gewone werk krijgen de leidinggevenden namelijk steeds meer te maken met nieuwe verantwoordelijkheden, bijvoorbeeld doordat ook het coachen van het personeel tot het takenpakket is gaan behoren". Een ander bedrijf, waar steeds meer met subcontractors wordt gewerkt, verwacht dat er in de toekomst meer leidinggevend personeel nodig zal zijn om de werkzaamheden van het externe en het eigen personeel te coördineren.

\section{Persoonskenmerken}

Wat voor soort werknemers werken er in de Metalektro? Het Werkgeverspanel biedt geen informatie over de persoonskenmerken van de werknemers in de Metalektro. Om hier toch enig zicht op te krijgen kijken we in figuur 2.3, op basis van cijfers van het CBS, naar een drietal persoonskenmerken. Aangezien het CBS een wat bredere definitie hanteert van de Metalektro, kunnen de cijfers enigszins vertekend zijn.

Het aantal vrouwelijk werknemers in de Metalektro is beperkt. Voor de sector als geheel gaat het om $13 \%$. De basismetaal heeft het laagste aandeel van vrouwelijke werknemers: één vrouw op 20 medewerkers. In de elektrotechniek is het aantal vrouwen veel groter: Ruim 1 op de 5 werknemers is vrouw.

Wanneer we kijken naar de leeftijdsopbouw van het personeelsbestand in de Metalektro valt meteen op dat de grootste groep werknemers $(60 \%)$ tussen de 30 en 49 jaar is. De groepen jongeren en oudere werknemers vertegenwoordigen ieder circa $20 \%$ van de totale werkgelegenheid in de sector. Het aantal oudere werknemers is bovengemiddeld hoog in de sectoren basismetaal en in de transportmiddelenindustrie. Naar verwachting zal de pensioenuitstroom in deze sectoren daarom ook het grootst zijn. In de metaalproduktenindustrie zien we een meer dan gemiddeld aandeel van jongere werknemers. Als laatste kijken we naar de verdeling van het personeelsbestand naar etniciteit. De Metalektro als geheel heeft $8 \%$ allochtone 
werknemers in dienst. In de basismetaal werken de meeste allochtone werknemers; in de machine-industrie daarentegen is het aantal allochtone werknemers beperkt.

Tabel 2.3

Persoonskenmerken van werkenden in de Metalektro, naar bedrijfssector, gemiddelde 20022003 (\% werkenden)

\begin{tabular}{ccccccc}
\hline Kenmerk & Basis- & Metaal- & Machine- & Elektro- \\
metaal & produkten & industrie & Transport- & Metalektro \\
$\%$ & $\%$ & $\%$ & $\%$ & $\%$ & $\%$ \\
\hline
\end{tabular}

Geslacht:

- Vrouw

- Man

Leeftijd:

- Jong (15-29)

- Middel (30-49)

- Oud (50-64)

Etniciteit:

- Allochtoon*

$\begin{array}{rr}5 & 1 \\ 95 & 9 \\ 12 & \\ 62 & 5 \\ 26 & 21 \\ 14 & \\ 86 & \end{array}$

$\begin{array}{rrr}10 & 11 & 22 \\ 90 & 89 & 78 \\ 21 & 19 & 16 \\ 58 & 63 & 62 \\ 21 & 18 & 22 \\ 8 & 6 & \\ 92 & 94 & 9\end{array}$

$\begin{array}{rrr}22 & 11 & 13 \\ 78 & 89 & 87 \\ 16 & 19 & 19 \\ 62 & 57 & 60 \\ 22 & 24 & 21 \\ & & \\ 9 & 9 & 8 \\ 91 & 91 & 92\end{array}$

\footnotetext{
* 'Allochtoon' heeft betrekking op niet-westerse allochtonen, iedereen waarvan ten minste één ouder in het buitenland is geboren, en waarvan de herkomst een niet-westers land is. Bron: CBS/Enquête Beroepsbevolking (EBB) 2002 en 2003

\section{Opleidingsniveau}

Wat is het opleidingsniveau van de werknemers in de Metalektro? Aangezien er in het Werkgeverspanel enkel informatie verzameld wordt over de functies waarin de medewerkers actief zijn, zijn we ook hier genoodzaakt gebruik te maken van informatie van het CBS. Doordat het CBS een ruimere definitie hanteert van de Metalektrosector kan het zo zijn dat de gegevens wat vertekend zijn.

Tabel 2.4 laat zien dat in de Metalektro bijna de helft van het personeel middelbaar opgeleid is. $15 \%$ van de werknemers heeft een opleiding op HBO-niveau en $5 \%$ heeft een opleiding op academisch niveau. Dat houdt in dat één derde van de werknemers een opleiding op VMBO-niveau heeft of ongeschoold is.

Tabel 2.4

Opleidingsniveau van werkenden in de Metalektro naar bedriffssector, gemiddelde 2002-2003 (\% werkenden)

\begin{tabular}{lcccccc} 
Opleidingsniveau & $\begin{array}{c}\text { Basis- } \\
\text { metaal } \\
\%\end{array}$ & $\begin{array}{c}\text { Metaal- } \\
\text { produkten } \\
\%\end{array}$ & $\begin{array}{c}\text { Machine- } \\
\text { industrie } \\
\%\end{array}$ & $\begin{array}{c}\text { Elektro- } \\
\text { techniek } \\
\%\end{array}$ & $\begin{array}{c}\text { Transport- } \\
\text { middelen } \\
\%\end{array}$ & Metalektro \\
\hline Basisonderwijs & 9 & 8 & 5 & 5 & 9 & 7 \\
VMBO & 25 & 34 & 23 & 19 & 30 & 26 \\
MBO/HAVO/VWO & 46 & 48 & 54 & 40 & 45 & 47 \\
HBO & 13 & 9 & 14 & 23 & 12 & 15 \\
WO & 7 & 1 & 4 & 13 & 4 & 5 \\
\hline
\end{tabular}

Bron: CBS/Enquête Beroepsbevolking (EBB) 2002 en 2003 


\section{Functiekenmerken}

Welke kenmerken hebben de functies van de werknemers bij de metalektrobedrijven? Tabel 2.5 laat zien dat het voor de meeste werknemers gaat om voltijds functies met een vast dienstverband. Toch zijn er tussen de verschillende sectoren in de Metalektro wel enige verschillen. Zo is het percentage werknemers met een deeltijdaanstelling in de elektrotechniek wat groter dan gemiddeld. Ongeveer één op de zeven werknemers in deze sector werkt in deeltijd. Werknemers met tijdelijke contracten komen het meest voor in de basismetaal. Toch is ook hier het aantal werknemers met tijdelijke contracten beperkt: slechts één op 14 werknemers in de basismetaal heeft geen vaste aanstelling.

Tabel 2.5

Kenmerken van de dienstverbanden in de Metalektro, naar bedrijfssector, gemiddelde 20022003 (\% werkenden)

$\begin{array}{lcccccc}\text { Kenmerk } & \begin{array}{c}\text { Basis- } \\ \text { metaal }\end{array} & \begin{array}{c}\text { Metaal- } \\ \text { produkten }\end{array} & \begin{array}{c}\text { Machine- } \\ \text { industrie }\end{array} & \begin{array}{c}\text { Elektro- } \\ \text { techniek }\end{array} & \begin{array}{c}\text { Transport- } \\ \text { middelen }\end{array} & \text { Metalektro } \\ & \% & \% & \% & \% & \% & \% \\ \begin{array}{l}\text { Deeltijd } \\ \text { Voltijd }\end{array} & 91 & 90 & 91 & 85 & 91 & 89 \\ \text { Tijdelijk } & 7 & 5 & 4 & 5 & 5 & 5 \\ \text { Vast } & 93 & 95 & 96 & 95 & 95 & 95\end{array}$

Bron: CBS/Enquête Beroepsbevolking (EBB) 2002 en 2003

\subsection{Werknemers zonder dienstverband}

Naast het personeel dat in dienst is bij de bedrijven zelf, maken veel bedrijven ook gebruik van tijdelijk ingeleend personeel, bijvoorbeeld van een uitzendbureau of via detachering. Daarom is er in het Werkgeverspanel van 2004 ook aandacht besteed aan personeel zonder dienstverband. Tabel 2.6 laat zien dat het personeel zonder dienstverband sterk geconcentreerd is bij de uitvoerende technische functies. Dit laat zien dat metalektrobedrijven vooral voor deze functies een grote behoefte hebben aan een flexibele omvang van hun personeelsbestand. In maar liefst bijna negen van de tien bedrijven is uitvoerend technisch personeel werkzaam dat niet in dienst is van de bedrijven zelf.

Ook voor de ontwikkeling- en engineeringfuncties werkt circa één derde van de bedrijven met personeel zonder dienstverband. Hieruit blijkt dat de mensen die werkzaam zijn in deze functies niet automatisch behoren tot de 'harde kern' van het personeelsbestand. Ten slotte werkt in de helft van de bedrijven ondersteunend, administratief of niet technisch verkooppersoneel zonder dienstverband.

Zoals verwacht mocht worden is er slechts bij weinig bedrijven personeel zonder dienstverband werkzaam in de leidinggevende technische functies en de hogere managementfuncties. Het gaat hier waarschijnlijk om functies die sterk verweven zijn met het bedrijf en waarbij continuïteit van belang is. 
Tabel 2.6

Personeel zonder dienstverband, naar functiecategorie, 2004 (\% bedrijven)

\begin{tabular}{lrr}
\hline Functiecategorie & $\begin{array}{r}\text { Mei- } \\
\text { augustus } \\
2004\end{array}$ & $\begin{array}{r}\text { September- } \\
\text { december }\end{array}$ \\
2004
\end{tabular}

Noot: De verschillende percentages staan los van elkaar en hoeven dus niet op te tellen tot $100 \%$.

Bron: $\quad$ ROA/Werkgeverspanel Metalektro 2004

Tabel 2.7 geeft een overzicht van het totaal aantal werknemers dat zonder dienstverband in de Metalektro werkzaam is. Het overgrote gedeelte van dit personeel heeft een uitvoerende technische functie. Het gaat hier om ruim 10.000 mensen. Een opvallende uitkomst is dat het aantal werknemers zonder dienstverband dat betrokken is bij ontwikkeling en engineering gedurende het jaar bijna verdubbeld is tot circa 2.900 werkenden. Circa 1.500 mensen met ondersteunende, administratieve of niet-technische verkoopfuncties zijn werkzaam in de Metalektro zonder in dienst te zijn bij het metalektrobedrijf waar ze werken. Voor de overige functiecategorieën (leidinggevende technische functies, technisch opgeleide verkopers en managementfuncties) zijn de absolute aantallen werkenden zonder dienstverband zeer klein.

Tabel 2.7

Aantal werknemers zonder dienstverband, naar functiecategorie, 2004

$\begin{array}{lrr}\text { Functiecategorie } & \begin{array}{r}\text { Mei- } \\ \text { augustus } \\ 2004\end{array} & \begin{array}{r}\text { September- } \\ \text { december }\end{array} \\ 2004\end{array}$

\footnotetext{
Noot: Aangezien niet alle bedrijven, die in de voorgaande tabel aangaven dat ze beschikken over personeel zonder een dienstverband, hier een aantal hebben ingevuld, kunnen de aantallen in deze tabel een (lichte) onderschatting van het feitelijke aantal zijn.

Bron: ROA/Werkgeverspanel Metalektro 2004
}

Uit de gesprekken die met deelnemers aan het Werkgeverspanel Metalektro gevoerd zijn blijkt duidelijk dat de bedrijven personeel zonder dienstverband inzetten om twee redenen: Enerzijds gaat het om het opvangen van tijdelijke pieken in de productie. 
Een HRM-manager: "wanneer het 'bloedstollend' druk is en we snel 'extra handen' nodig hebben, werkt er bij ons $10 \%$ extra personeel op uitzendbasis". Anderzijds zien sommige bedrijven het tijdelijk inhuren van personeel als een manier om te zien of bepaalde mensen geschikt zijn voor een functie met een dienstverband in het eigen bedrijf. Een bedrijf uit de transportmiddelensector: "we willen voorkomen dat we risicovol personeel in dienst nemen en huren daarom mensen vaak eerst via een uitzendbureau in om te kijken of ze in ons bedrijf passen".

Een andere afweging die bedrijven moeten maken bij de keuze tussen personeel in dienstverband en flexibel ingeleend personeel zijn de kosten. Flexibel ingehuurd personeel is in het algemeen veel duurder. Daarom vinden sommige bedrijven dat het slechts in uitzonderlijke gevallen moet worden ingezet: "Tijdelijk personeel wordt bij ons steeds minder ingezet, omdat het regelmatig flexibel inhuren van personeel gewoon te duur wordt. Daarom hebben we onlangs het aantal vaste contracten weer verhoogd". Andere bedrijven zien dit heel anders: "Wij nemen de komende jaren helemaal geen eigen personeel meer aan. We maken soms gebruik van een uitzendbureau om onze flexibiliteitsbehoefte op te vangen, maar dit gebeurt ook door subcontracting. Die samenwerking met kleinere onderaannemers werkt erg goed. We hebben de indruk dat het personeel van deze bedrijven in het algemeen wat harder werkt dan ons eigen personeel". Bij een ander bedrijf zegt men genoodzaakt te zijn vaak gebruik te maken van ingehuurd personeel, omdat het erg moeilijk is om de behoefte aan personeel in de toekomst in te schatten: "we werken op projectbasis en daarom kunnen we van te voren moeilijk inschatten hoeveel personeel we nodig hebben."

Natuurlijk kunnen bedrijven er ook voor kiezen om werknemers in eigen dienst te nemen met een flexibel contract. Een high-tech bedrijf: "Wij geven er de voorkeur aan om personeel tijdelijk in dienst te nemen. Ongeveer $5 \%$ van ons personeel heeft een jaarcontract". Een groot bedrijf in de Metalektro probeert daarentegen de benodigde flexibiliteit vooral vanuit het vaste personeel in het eigen bedrijf te realiseren: "We gebruiken weliswaar ingehuurd personeel, maar we hebben ook een eigen flexpool van mensen die op verschillende plaatsen in het bedrijf kunnen worden ingezet. Meestal gaat het om goed gemotiveerde laagopgeleide werknemers, die bereid zijn om zich verder te laten scholen. Die aanpak werkt erg goed: ruim $90 \%$ van de flexpoolers wordt ook daadwerkelijk tot MBO niveau 2 bijgeschoold".

Omdat circa één op de drie bedrijven tijdelijk personeel inhuurt dat betrokken is bij ontwikkeling en engineering is daar in de gesprekken met deelnemende bedrijven ook aandacht aan besteed. Bij sommige bedrijven gaat het hier duidelijk om specifieke projecten waarvoor tijdelijk engineers worden ingehuurd: "We hebben weliswaar ook zelf engineers in dienst, maar voor tijdelijke projecten huren we hoogopgeleide technische mensen in". In een bedrijf waar dat niet gebeurt: "We nemen onze engineers altijd zelf in dienst, maar voor een speciale klus is dat soms wel op basis van een tijdelijk arbeidscontract".

Het inhuren van tijdelijk personeel dat betrokken is bij ontwikkeling en engineering is niet zonder gevaren voor de concurrentiepositie. Na hun vertrek zou bedrijfskritieke 
informatie immers in handen van de concurrentie kunnen komen. Bedrijven denken uiteenlopend over het risico van het weglekken van belangrijke informatie. Een HRMfunctionaris in de automotivesector: "We zien dat helemaal niet als een probleem. We werken met contracten waarin geheimhoudingsclausules staan. Een paar jaar geleden is er wel een incident geweest met een tijdelijke kracht, maar doordat we het van te voren juridisch goed geregeld hadden, konden we snel ons gelijk bij de rechtbank halen". Een high-tech bedrijf ziet dat duidelijk anders: "Werkvoorbereiders en engineers lenen we wel in, maar niet bij fundamentele ontwikkelingsactiviteiten. Dat zou ook niet slim zijn vanwege mogelijke kennislekken". 



\section{Arbeidsmarktdynamiek}

In dit hoofdstuk kijken we naar de arbeidsmarktdynamiek in de metalektrosector. We beginnen met een beknopt beeld van de instroom van nieuw personeel, de uitstroom van personeel en de arbeidsmarktdynamiek in de periode 2002-2004. Daarna volgt een gedetailleerd overzicht van de ontwikkelingen in 2004. Hoeveel nieuwe werknemers vonden er in 2004 een baan in de Metalektro en waar kwamen ze vandaan? Welke werknemers stroomden er in dat jaar uit? Vervolgens gaan we in op de interne doorstroom van personeel in 2004 en de door de bedrijven gebruikte HRM-instrumenten om deze doorstroom te bevorderen.

\subsection{Instroom, uitstroom en dynamiek in de jaren 2002-2004}

Figuur 3.1 geeft een overzicht van de arbeidsmarktdynamiek in de Metalektro van de afgelopen drie jaar. Gedurende bijna de hele periode was het niveau van de instroom lager dan de uitstroom, wat inhoudt dat de werkgelegenheid afnam. Uit de cijfers blijkt wel dat de werkgelegenheidskrimp in 2004 minder sterk was dan in de jaren daarvoor. In de eerste vier maanden van 2004 was de instroom zelfs gelijk aan de uitstroom, waardoor er tijdelijk geen sprake was van een krimpende werkgelegenheid.

Figuur 3.1

Het totaalbeeld van de instroom, uitstroom, werkgelegenheidsontwikkeling en arbeidsmarktdynamiek in de Metalektro, 2002, 2003 en 2004, per viermaandelijkse periode

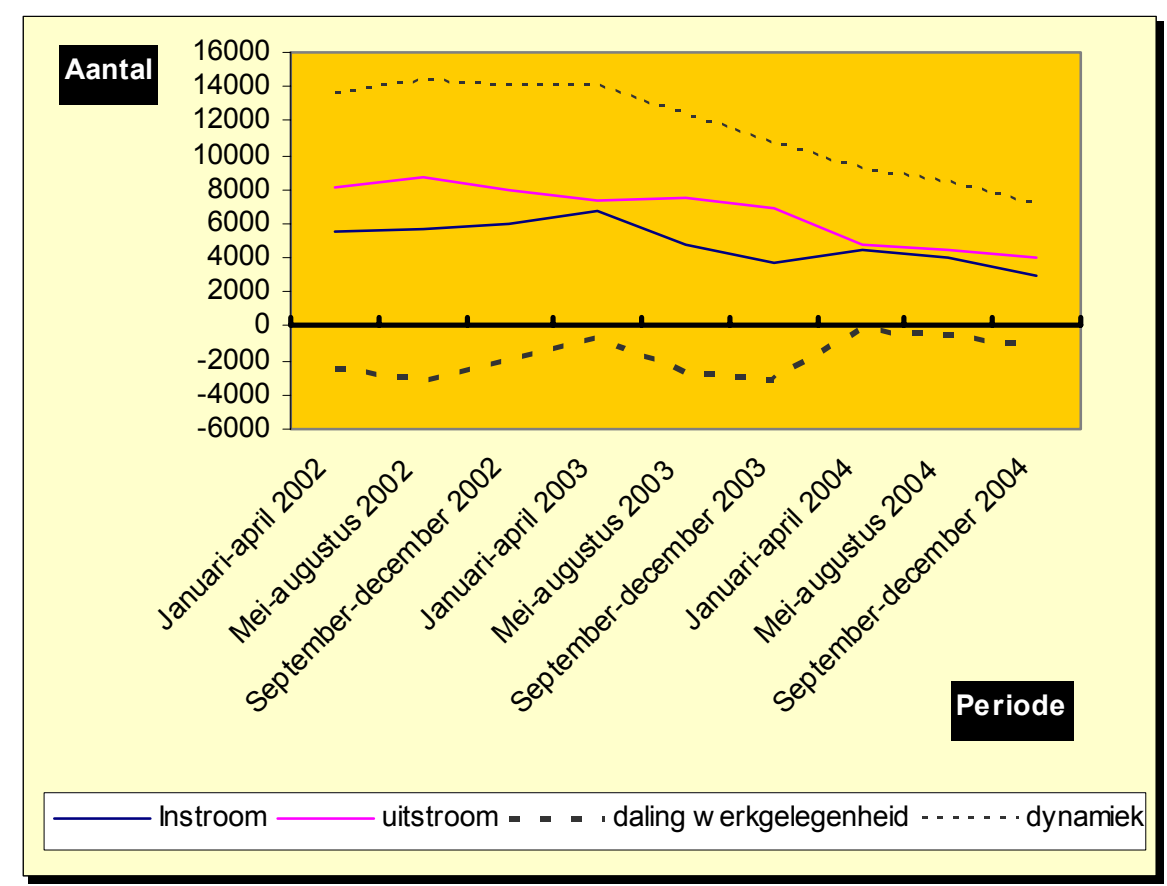

Noot: De cijfers voor 2002 en 2003 zijn herschaald op perioden van 4 maanden.

Bron: ROA/Werkgeverspanel Metalektro 2002, 2003, 2004 
Een tweede belangrijke conclusie die op basis van figuur 3.1 kan worden getrokken is dat de totale arbeidsmarktdynamiek (gemeten als de som van de instroom en uitstroom) de laatste jaren steeds kleiner wordt. De metalektrobedrijven 'verversen' hun personeel blijkbaar steeds minder door het personeel in en uit te laten stromen. Deze minder grote dynamiek kan wellicht verklaard worden door het feit dat de werkgelegenheid krimpt, waardoor er minder werknemers worden vervangen als ze uitstromen. Daarnaast zullen werknemers in de minder gunstige economische situatie ook minder snel geneigd zijn van baan te wisselen, wat zowel een negatief effect heeft op de uitstroom als op de instroom van nieuwe medewerkers.

\subsection{Steeds minder nieuwe werknemers}

Voor welke functies daalt de instroom van nieuwe werknemers het sterkst? Figuur 3.2 geeft daarvan een overzicht. Het blijkt dat de instroom bij zowel het uitvoerend technisch, het ondersteunend als het personeel betrokken bij ontwikkeling en engineering behoorlijk is gedaald. Voor het ondersteunend, administratief en niettechnisch verkooppersoneel is de instroom van nieuwe medewerkers gedurende het jaar zelfs meer dan gehalveerd. De instroom van nieuw leidinggevend technisch en managementpersoneel is daarentegen gedurende 2004 niet gedaald. Opvallend is dat voor deze functies de instroom in de maanden mei-augustus op een hoger niveau lag dan aan het begin en het eind van het jaar.

Figuur 3.2

Aantal nieuwe werknemers per vier maanden in 2004, naar functiecategorie

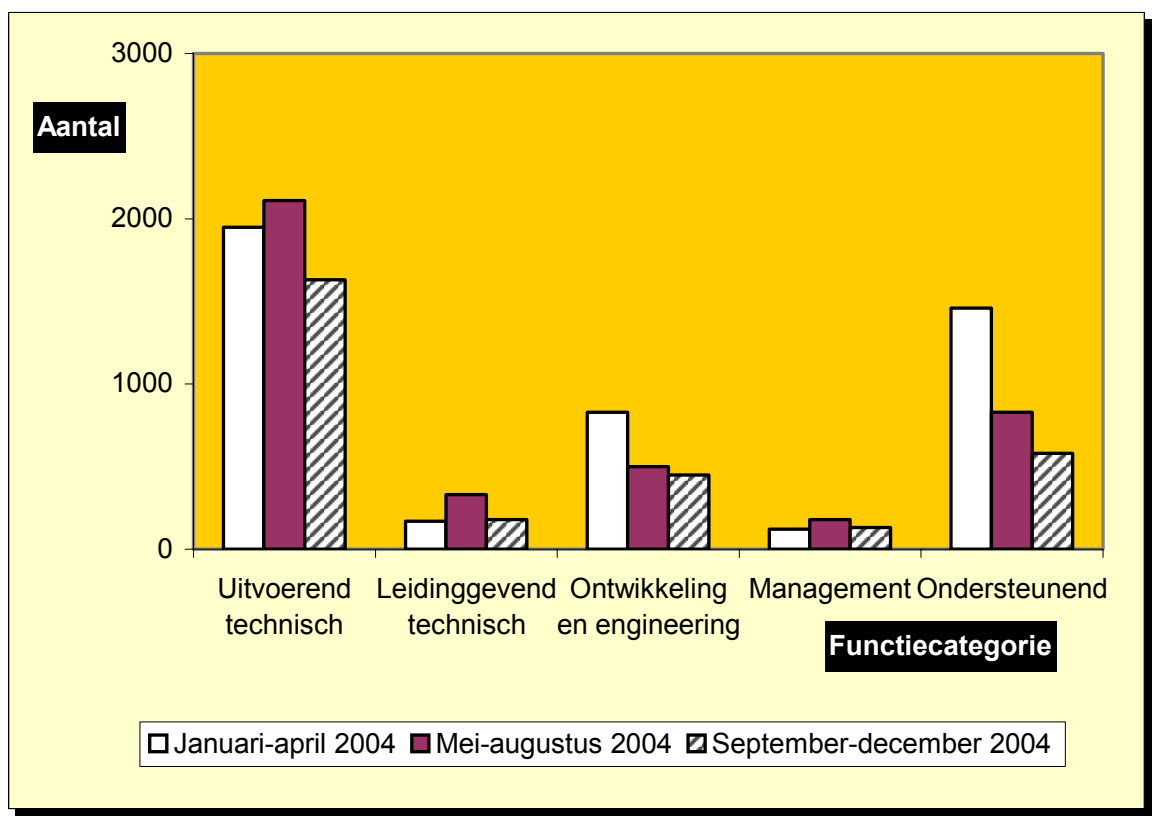

Bron: ROA/Werkgeverspanel Metalektro 2004 


\section{Herkomst van nieuwe werknemers}

Waar komen deze nieuwe werknemers vandaan? Tabel 3.1 geeft daarvan een overzicht. In bijna zes op de tien bedrijven komt een deel van het nieuw ingestroomde personeel van een ander bedrijf binnen de Metalektro. lets meer dan de helft van de bedrijven geeft aan dat een deel van het nieuwe personeel afkomstig is van een bedrijf buiten de metalektrosector. In circa één op de drie bedrijven is een gedeelte van het nieuwe personeel schoolverlater. Uit achterliggende gegevens blijkt dat de regio Noord/Oost op kop loopt bij het aannemen van schoolverlaters. Bijna de helft van de bedrijven in die regio nam in 2004 schoolverlaters in dienst. Slechts $12 \%$ van de bedrijven heeft in 2004 werklozen in dienst genomen, terwijl geen enkel bedrijf in 2004 herintreders of (gedeeltelijk) arbeidsongeschikten in dienst nam.

Tabel 3.1

Herkomst van nieuwe technische werknemers, 2004 (\% bedrijven)

Herkomst

Afkomstig van ander bedrijf binnen de Metalektro

Schoolverlaters

Anders

Werklozen

Afkomstig van zelfde bedrijf maar andere vestiging

Herintreders

(gedeeltelijk) arbeidsongeschikten

Noot: De verschillende percentages staan los van elkaar en hoeven dus niet op te tellen tot $100 \%$.

Bron: ROA/Werkgeverspanel Metalektro 2004

De volgorde van de groepen waaruit bedrijven nieuw personeel rekruteren laat duidelijk zien welke voorkeuren de bedrijven hebben voor de verschillende groepen arbeidsaanbod. Deze volgorde hangt natuurlijk sterk samen met de inzetbaarheid en beschikbaarheid van nieuw personeel. De gesprekken met bedrijven die aan het Werkgeverspanel deelnemen bieden op dat punt wat meer duidelijkheid. Een bedrijf gaf aan dat ze bij het werven van nieuw personeel koste wat kost wil voorkomen dat er 'risicovolle medewerkers' aangetrokken worden. Toch sluit men het aannemen van werkzoekenden niet uit: "Dat werklozen in het algemeen wat meer risico met zich meebrengen, betekent niet dat we ze nooit aannemen. lemand met een goed CV en een behoorlijke werkervaring, die korte tijd werkloos is, zullen we bij geschiktheid voor de functie zeker aannemen". Twee andere bedrijven beamen dat. De personeelsfunctionarissen zeggen dat "het bedrijf in eerste instantie naar het CV van een sollicitant kijkt en niet stigmatiseert" en dat "het niet echt uitmaakt of iemand werkloos is geweest, zolang het maar een goede werknemer is".

Wanneer we de uitkomsten voor 2004 vergelijken met de cijfers voor 2003, dan blijkt dat in 2004 meer bedrijven personeel aantrekken dat afkomstig is van een ander bedrijf, binnen of buiten de Metalektro. Een ander opvallend verschil is dat in 2004 veel meer bedrijven aangaven schoolverlaters in dienst te nemen dan in 2003. In 
2003 nam slechts $12 \%$ van de bedrijven schoolverlaters in dienst. De toename van het aantrekken van schoolverlaters illustreert waarschijnlijk het besef van een aantal bedrijven om voldoende jongeren in dienst te nemen met het oog op de te verwachten personeelstekorten in de toekomst vanwege de vergrijzing van hun personeelsbestand. Uit één van de gesprekken met deelnemers van het Werkgeverspanel blijkt echter dat er ook andere beweegredenen kunnen zijn om schoolverlaters aan te nemen. Een high-tech bedrijf stelt dat schoolverlaters bepaalde voordelen kunnen hebben voor het bedrijf: "schoolverlaters hebben weliswaar wat minder werkervaring, maar wel vaak een beter ontwikkeld leervermogen”.

\subsection{Wie stroomt er uit?}

Naast de instroom van nieuw personeel hebben de bedrijven in de Metalektro vanzelfsprekend ook te maken met personeel dat vertrekt. Maar om welke functies gaat het dan vooral? Uit figuur 3.3 blijkt dat de uitstroom het grootst is voor werknemers met een uitvoerende technische functie. In ledere periode stroomden er ruim 2.000 uitvoerende technici uit. Dit is telkens circa $2,5 \%$ van het totaal aantal werkzame uitvoerende technici die de bedrijven in dienst hebben.

Figuur 3.3

Aantal vertrokken werknemers per vier maanden in 2004, naar functiecategorie

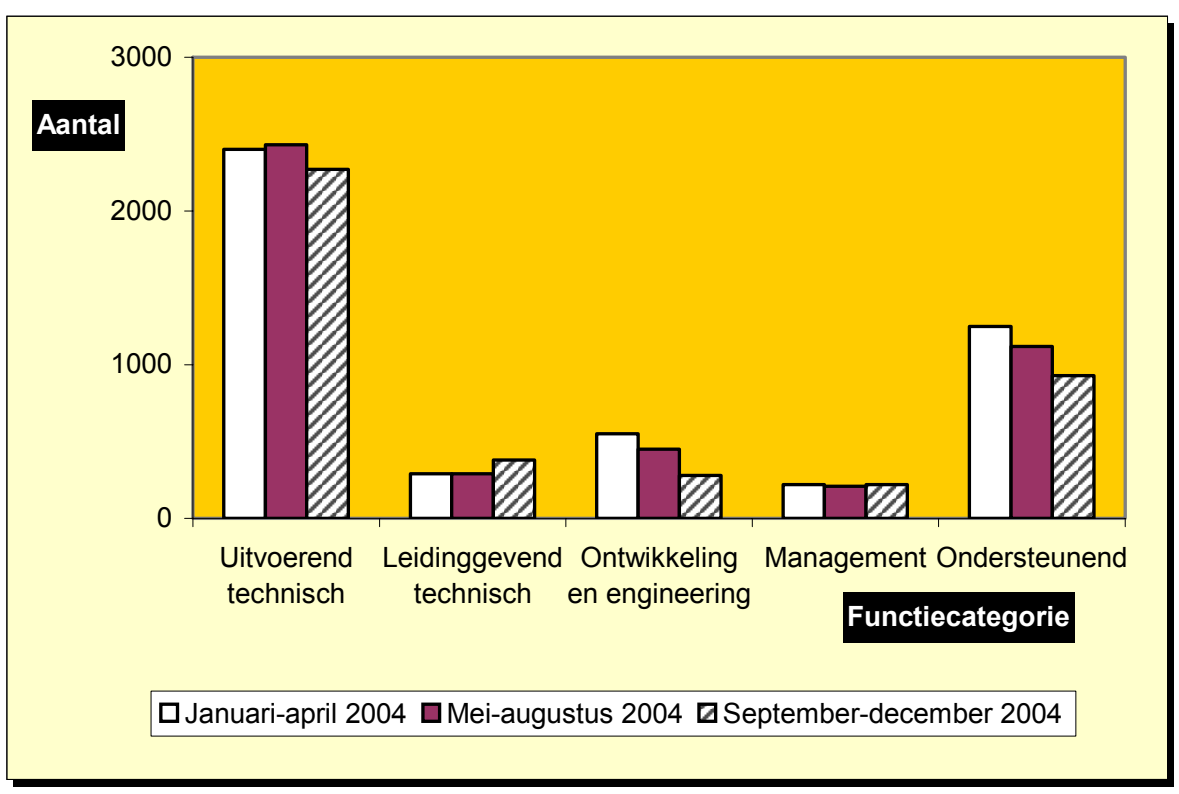

Bron: ROA/Werkgeverspanel Metalektro 2004

Op de tweede plaats komt de uitstroom van personeel met een ondersteunende, administratieve of technische verkoopfunctie. In 2004 stroomden er iedere viermaandelijkse periode circa 1.000 werknemers met een dergelijke functie uit. Het valt op dat de uitstroom van uitvoerend technisch personeel redelijk constant is, terwijl er voor het ondersteunende personeel sprake is van een duidelijk dalende uitstroom. 
Voor de overige functiecategorieën is de uitstroom van personeel in absolute aantallen beperkt. Voor zowel leidinggevend technisch personeel als personeel in managementfuncties bedroeg de uitstroom iedere vier maanden enkele honderden personeelsleden. Voor het personeel dat betrokken is bij ontwikkeling en engineering bedroeg de uitstroom in de eerste vier maanden van 2004 nog circa 500; in de loop van het jaar daalde de uitstroom echter steeds verder.

\subsection{Personeelsverloop en arbeidsmarktdynamiek}

In hoeverre vinden de bedrijven dat het verloop van hun personeel groot of klein is? Tabel 3.2 geeft daarop een antwoord. Slechts $3 \%$ van de bedrijven vindt dat hun personeelsverloop erg groot is. Het blijkt dat de overgrote meerderheid van de bedrijven in de Metalektro vindt dat er sprake is van (erg) weinig of geen personeelsverloop. Dat heeft ongetwijfeld te maken met het feit dat er in 2004 ten opzichte van vorige jaren minder sprake was van in- en uitstroom van personeel. Het kan er ook op wijzen dat veel bedrijven hun personeelsbestand liever wat sneller zouden willen kunnen aanpassen door middel van een hoger personeelsverloop dan ze momenteel kunnen realiseren.

Tabel 3.2

Beoordeling van het verloop van technisch personeel, 2004 (\% bedrijven)

Beoordeling

Erg veel personeelsverloop

Veel personeelsverloop

Gemiddeld personeelsverloop

Weinig personeelsverloop

Erg weinig of geen personeelsverloop

Bron: ROA/Werkgeverspanel Metalektro 2004

Tijdens de gesprekken met metalektrobedrijven kwam naar voren dat sommige bedrijven inderdaad vinden dat het beter zou zijn als er sprake is van wat meer in- en uitstroom. Een personeelsfunctionaris van een bedrijf met veel hoogopgeleide werknemers: "Momenteel is de in- en uitstroom van personeel erg laag. We zouden graag een in- en uitstroompercentage van $10 \%$ hebben. Maar in de huidige arbeidsmarktsituatie is dat niet te realiseren. Toen het enkele jaren geleden nog beter ging lag de in- en uitstroom van personeel ook stukken hoger, omdat de mensen ook buiten het bedrijf makkelijk terecht konden". Een collega bij een ander bedrijf bevestigt dat: We hebben nu een verloop van circa $3 \%$ en dat vinden we aan de lage kant. Enkele jaren geleden lag dat nog een stuk hoger. Toch willen we ook niet heel hoge verloopcijfers. Dat zou de continuïteit namelijk niet ten goede komen". Een HRM-manager van een bedrijf met veel laag en middelbaar opgeleide werknemers: "Persoonlijk vind ik de lage personeelsdynamiek wel een punt van zorg. Maar binnen dit bedrijf is er weinig aan te veranderen. Het idee dat mensen tot hun pensioen in dezelfde functie zitten zit in de cultuur van deze regio en dit bedrijf. Daar is met het beleid van het bedrijf ook weinig aan te doen". 


\section{Arbeidsmarktdynamiek per functiecategorie}

Figuur 3.4 geeft per functiecategorie een overzicht van de arbeidsmarktdynamiek (de som van in- en uitstroom). Doordat het grootste gedeelte van het personeel een uitvoerende technische functie heeft, is het logisch dat de arbeidsdynamiek het grootst is voor deze functies. In totaal stroomden er in 2004 in de Metalektro ruim 12.000 uitvoerende technici in of uit. Op de tweede plaats komen de ondersteunende, administratieve, en niet-technische verkoopfuncties. 6.500 werknemers met dergelijke functies stroomden in 2004 in of uit. De arbeidsmarktdynamiek voor de overige functiecategorieën ligt een stuk lager.

Het is opvallend dat, ten opzichte van voorgaande jaren, gedurende het jaar 2004 de arbeidsmarktdynamiek over de gehele linie gedaald is. Zowel voor uitvoerend technisch, ondersteunend als ook voor personeel dat zich bezig houdt met ontwikkeling en engineering daalde de arbeidsmarktdynamiek. Uit de figuren 3.2 en 3.3 bleek dat dit zowel het gevolg was van een afnemende personeelsuitstroom als van het feit dat een geringer deel van het uitstromend personeel werd vervangen door nieuw personeel. Voor leidinggevend technisch en managementpersoneel was er gedurende 2004 geen daling, maar bleef de dynamiek redelijk constant.

Figuur 3.4

Arbeidsmarktdynamiek naar functiecategorie, 2004

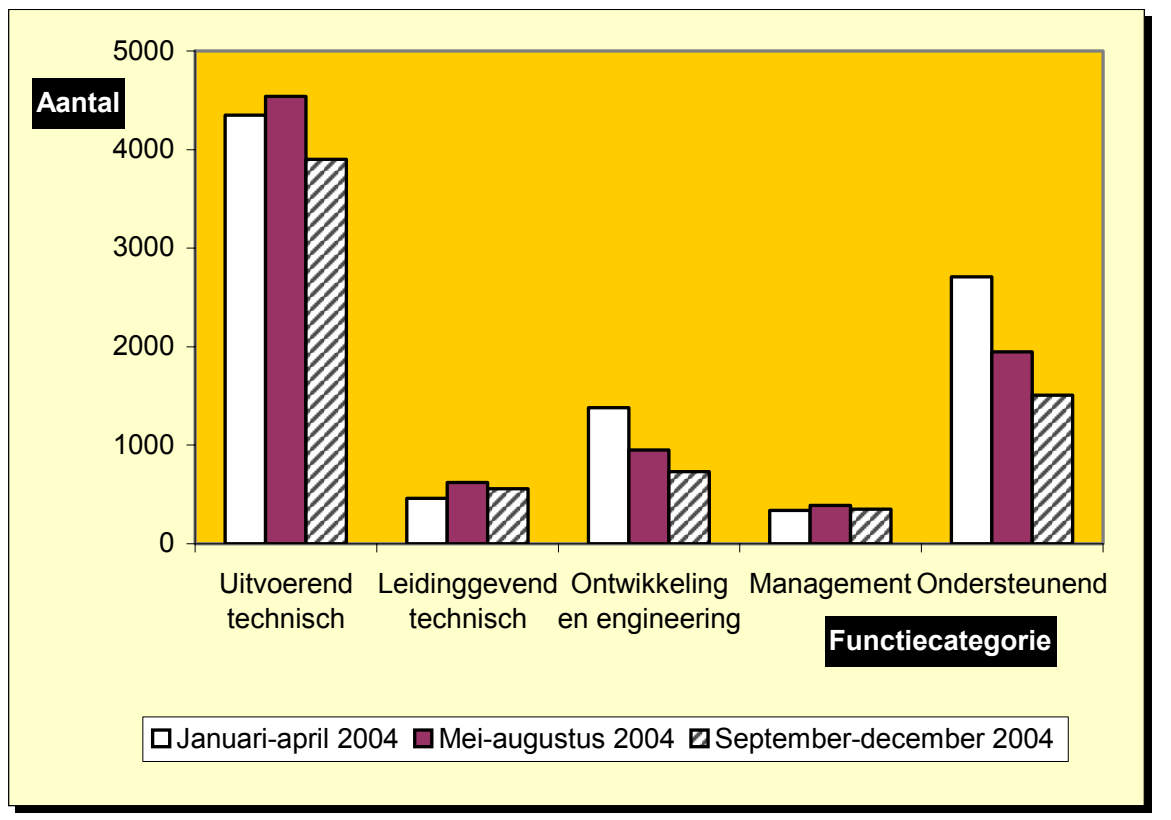

\subsection{Doorstroom geeft ruimte}

Ook binnen het bedrijf kan het personeel van functie veranderen. In dat geval spreken we van de doorstroom van personeel. Zowel voor bedrijven als voor de 
betrokken werknemers kan het doorstromen naar andere functies belangrijke voordelen bieden. Aan bedrijven biedt het bijvoorbeeld de mogelijkheid om werknemers in bepaalde lagere functies, waarin sprake is van een krimpende werkgelegenheid, om- of bij te scholen en door te laten stromen functies op een hoger niveau en de vrijkomende arbeidsplaatsen niet opnieuw in te vullen. Ook illustreert de doorstroom van werknemers de employability van het personeel, in termen van de inzetbaarheid in andere functies. De doorstroom van personeel kan zowel voor bedrijven als voor werknemers van belang zijn. Zo geeft het bedrijven de mogelijkheid om arbeidsplaatsen te schrappen waaraan geen behoefte meer is. Daarnaast kan de doorstroom van personeel ook een belangrijke rol spelen voor de motivatie van het personeel. Voor het personeel betekent het bestaan van doorstroommogelijkheden immers dat er kansen zijn om binnen het eigen bedrijf verder te komen in de eigen loopbaan. Men spreekt in dit verband ook wel van een 'interne arbeidsmarkt'.

Tabel 3.3 geeft een overzicht van de mate waarin er binnen de bedrijven doorstroom plaatsvindt. In $58 \%$ van de bedrijven gebeurt dit helemaal niet. Bij de bedrijven waar er in 2004 wel sprake was van doorstroom gaat het bij het grootste deel (35\%) om doorstroom van een bepaalde technische functie naar een andere technische functie. In slechts $12 \%$ van de bedrijven was er in 2004 sprake van doorstroom van technische naar niet-technische functies.

Tabel 3.3

Doorstroom van technische werknemers in de laatste 12 maanden, 2004 (\% bedrijven)

Doorstroom

Ja, naar andere technische functies

$\mathrm{Ja}$, naar niet-technische functies

Nee

Noot: De verschillende percentages staan los van elkaar en hoeven dus niet op te tellen tot $100 \%$.

Bron: $\quad$ ROA/Werkgeverspanel Metalektro 2004

Naar welk niveau stromen de technische werknemers door? Tabel 3.4 laat zien dat in $70 \%$ van de bedrijven waar technisch personeel doorstroomt naar andere functies er sprake is van doorstroom naar een hoger niveau. $\mathrm{Bij} 59 \%$ van deze bedrijven stroomt er ook personeel door naar technische functies op hetzelfde niveau. In slechts één op de tien bedrijven met interne doorstroom, is er ook sprake van 'demotie': doorstroom van technische werknemers naar functies op een lager niveau.

De doorstroom naar functies op een hoger niveau geeft aan welke doorgroeimogelijkheden het technisch personeel in een bedrijf heeft. Voor bedrijven heeft een degelijke 'interne arbeidsmarkt' vaak het voordeel dat men voor senior functies en leidinggevende functies mensen kan aantrekken die over voldoende bedrijfsspecifieke kennis en vaardigheden beschikken. De 'horizontale' doorstroom naar 
functies op hetzelfde niveau illustreert, zoals eerder reeds werd opgemerkt, de employability van het personeel, in termen van hun bredere inzetbaarheid.

Tabel 3.4

Niveau van de doorstroom naar technische functies in laatste 12 maanden, 2004 (\% bedrijven) ${ }^{\star}$

Niveau

Hoger niveau dan de vorige technische functies

Noot: De verschillende percentages staan los van elkaar en hoeven dus niet op te tellen tot $100 \%$.

* De bedrijven zonder personeelsdoorstroom zijn hier buiten beschouwing gelaten

Bron: ROA/Werkgeverspanel Metalektro 2004

Het aantal doorgestroomde technici was overigens in 2004, net als in vorige jaren, beperkt. Tabel 3.5 laat zien dat er in totaal circa 1.000 technische werknemers doorstroomden naar een technische functie op een hoger niveau. Dat is circa $1 \%$ van het totaal aantal werkende technici. De opwaartse mobiliteit lag daarmee op een lager niveau dan in 2003, toen circa 2.000 mensen doorstroomden naar een hogere functie. 1140 technici verruilden hun functie voor een andere technische functie op hetzelfde niveau. Ook de horizontale mobiliteit lag hiermee op een lager niveau dan in 2003 , toen er nog 1.800 technici doorstroomden naar een functie op hetzelfde niveau.

De bedrijven waarmee gesprekken gevoerd zijn verschillen van mening over de noodzaak van interne doorstroom. Een personeelsmanager van een bedrijf met vooral laaggeschoold personeel geeft aan dat "doorstroom geen issue is omdat we nogal een stabiele organisatie zijn”. Een HRM-functionaris van een bedrijf met veel hoogopgeleid personeel vindt daarentegen het doorstroompercentage voor de Metalektro als geheel "dramatisch laag": "Bij ons is de doorstroom elk jaar circa 7\% van het personeelsbestand. Het is gewoon een keiharde noodzaak dat er voldoende doorstroom is anders is ons bedrijf binnen 5 jaar reddeloos verloren”. De functionaris geeft verder aan dat hij het goed vindt dat er in de Metalektro veel aandacht is voor het opleiden van het personeel, maar dat "dat te vaak als een doel op zich wordt gezien. Bij ons staan de opleidingen in het teken van het oplossen van kennistekorten bij doorstroom". Een ander bedrijf ziet het doorstromen op zich ook als een belangrijke leermogelijkheid: "Bij ons doet iedereen gemiddeld 3 jaar dezelfde functie. Dit is dé manier om mensen bij te laten leren. Regelmatige doorstroom houdt het personeel gewoon veel langer fit".

Overigens verloopt de doorstroom van personeel in niet alle bedrijven even goed. Een HRM-manager van een metaalbewerkend bedrijf: "Het zou mooi zijn als de doorstroom van personeel 'de gaten zou opvullen' van het personeel in de hogere functies dat vertrekt. Jammer genoeg komt daar in de praktijk weinig van terecht. De mensen trekken er niet zo aan, en wanneer er een beroep wordt gedaan op hun 
flexibiliteit zijn ze meestal helemaal niet bereid om door te stromen naar een andere functie".

Het aantal technici dat doorstroomde naar een technische functie op een lager niveau dan hun oorspronkelijke baan is nog steeds gering, maar is toch opvallend hoger dan in de voorgaande jaren. In 2004 was er bij 100 technici sprake van demotie, tegenover slechts 20 in 2003 en 10 in 2002. Uit de gesprekken met deelnemende bedrijven blijkt dat het hierbij met name om oudere werknemers gaat, die aan het einde van de loopbaan functies krijgen waarin de overdracht van kennis aan het jongere personeel of de ondersteuning van de primaire processen op de werkvloer centraal staat.

Tabel 3.5

Aantal doorgestroomde technische werknemers naar niveau in laatste 12 maanden, 2004

Niveau

Aantal

Hoger niveau dan de vorige technische functies

Bron: ROA/Werkgeverspanel Metalektro 2004

Met de toekomstige vergrijzing van het personeelsbestand zal deze doorstroom mogelijk nog van groter belang worden. Een HRM-manager van een bedrijf actief in de transportmiddelensector: "Bij ons laten we oudere werknemers vaak doorstromen naar werk dat wat meer buiten de productielijnen ligt. Het komt dus voor dat mensen doorstromen naar lagere functies, maar in salaris gaan ze er nooit op achteruit". Bij een ander bedrijf behoort dat laatste wel tot de mogelijkheden. Omdat het pensioensysteem in de Metalektro pas geleden herzien is, en het pensioen niet meer berekend wordt op basis van het laatst verdiende loon, maar op het gemiddelde loon gedurende de loopbaan, is het makkelijker geworden om het inkomen bij een overstap naar een lagere functie te laten dalen: "De financiële gevolgen voor de werknemer zijn immers veel geringer dan in het verleden".

Een derde bedrijf speelt actief in op de mogelijke problemen bij oudere werknemers door hen vanaf de leeftijd van 50 jaar ieder jaar te beoordelen op hun fysieke capaciteiten. Daarnaast krijgt het personeel van 55 jaar en ouder de mogelijkheid om onder dezelfde arbeidsvoorwaarden 4 dagen in de week te gaan werken. Ten slotte wordt er ook in het werk rekening gehouden met de leeftijd. Oudere werknemers hoeven bepaalde taken niet meer uit te voeren. De personeelsfunctionaris benadrukt dat het hier gaat om een soort informeel beleid: "De leidinggevenden weten precies wat het oudere personeel niet goed meer kan en houden daarmee in de werkplanning rekening".

Het is duidelijk dat de mogelijkheden van doorstroom van oudere werknemers naar functies op een lager niveau wel vaak beperkt wordt door het geringe aantal functies 
op lager niveau dat er in veel bedrijven nog is. Een middelgroot bedrijf verwoordde het als volgt: "Doorstroom naar lagere functies komt voor, maar het is een randfenomeen, eenvoudigweg omdat we niet zo heel veel van dat soort functies nodig hebben. Het komt ook alleen maar voor wanneer iemand flinke fysieke beperkingen krijgt of (gedeeltelijk) arbeidsongeschikt wordt. Dat past ook in ons beleid: we kijken naar welke functies echt nodig zijn en in welke afdelingen van het bedrijf er het meeste behoefte aan is".

\section{Doorstroom naar niet-technische functies}

Wat gebeurt er met technici die naar een niet-technische functie doorstromen? Tabel 3.6 laat zien dat er in ruim van de helft van de bedrijven waar er sprake is van doorstroom van technici naar niet-technische functies, de mensen naar functies op een hoger niveau doorstromen. Waarschijnlijk gaat het hier vooral om doorstroom van technische functies naar managementfuncties. In iets meer van een derde van de bedrijven vindt er ook doorstroom plaats van technische functies naar niettechnische functies op hetzelfde niveau. In slechts $16 \%$ van de bedrijven is er sprake van doorstroom naar niet-technische functies op een lager niveau.

Tabel 3.6

Niveau van de doorstroom van technische naar niet-technische functies in laatste 12 maanden, 2004 (\% bedrijven)

Niveau

Hoger niveau dan de vorige technische functies $\quad 53$

Hetzelfde niveau als de vorige technische functies $\quad 37$

Lager niveau dan de vorige technische functies $\quad 16$

Noot: $\quad$ De verschillende percentages staan los van elkaar en hoeven dus niet op te tellen tot $100 \%$.

Bron: $\quad$ ROA/Werkgeverspanel Metalektro 2004

De doorstroom van niet-technisch personeel naar technische functies ligt niet direct voor de hand. Immers, veel technische functies vereisen een specialistische opleiding. Het is dan ook niet verwonderlijk dat er in slechts $8 \%$ van de bedrijven doorstroom van niet-technische werknemers naar technische functies plaatsvindt. Per saldo is er dus duidelijk sprake van een afname van het technisch personeel vanwege de interne doorstroom van werknemers.

\section{HRM-beleid om doorstroom te stimuleren}

Sommige werknemers in metalektrobedrijven kunnen doorstromen zonder dat de bedrijven daar extra inspanningen voor leveren, bijvoorbeeld wanneer werknemers zelf actief bepaalde loopbaanstappen ambiëren. Echter, ook voor de bedrijven is er een belangrijke rol weggelegd. Door het HRM-beleid in de onderneming kan er actief worden gewerkt aan een bedrijfscultuur waarin er sprake is van een regelmatige horizontale en verticale doorstroom van het personeel. Een personeelsfunctionaris van een groot bedrijf formuleert het als volgt: "Ons personeel moet binnen de 
organisatie kunnen groeien. Daarom stimuleren we op allerlei manieren dat het personeel zich voldoende kan ontwikkelen. Je ziet ook dat mensen na bepaalde opleidingstrajecten in hogere functies terechtkomen".

Tabel 3.7 geeft een overzicht van de HRM-instrumenten die de metalektrobedrijven inzetten om de doorstroom van hun technisch personeel te bevorderen. Daarbij wordt er een onderscheid gemaakt tussen HRM-instrumenten die voor alle technici worden ingezet en instrumenten die voor een meerderheid van het technisch personeel worden gebruikt. Uit de tabel blijkt dat de meeste bedrijven de interne doorstroom van het technisch personeel proberen te bevorderen door het aanbieden van opleidingsfaciliteiten. De meeste bedrijven doen dit ook vanuit een bedrijfsopleidingplan. Daarnaast zien veel bedrijven het houden van functionerings gesprekken, beoordelingsgesprekken en scholingsgesprekken en het geregeld houden van werkoverleg als belangrijke instrumenten om de doorstroom te bevorderen. Een opmerkelijke uitkomst is dat loopbaanplanning en functieroulatie slechts door een minderheid van de bedrijven wordt ingezet als instrument voor het doorstroombeleid.

Tabel 3.7

Gebruikte HRM-instrumenten om de doorstroom van het technisch personeel te bevorderen 2004 ( $\%$ bedrijven)

HRM-instrument

$\begin{array}{cc}\begin{array}{c}\text { Voor alle } \\ \text { technische } \\ \text { werknemers }\end{array} & \begin{array}{c}\text { Voor een } \\ \text { meerderheid van } \\ \text { de technische } \\ \text { werknemers }\end{array} \\ \% & \%\end{array}$

$\%$

Scholing en competenties

Opleidingsfaciliteiten

Bedrijfsopleidingplan (BOP)

Persoonlijk Ontwikkelingsplan (POP)

Competentiematrix

Erkenning Verworven Competenties (EVC)

Mobiliteit

Loopbaanplanning

Functieroulatie

Uitwisseling werknemers met andere bedrijfsvestigingen

Loopbaanadvies/mobiliteitscentrum

$\begin{array}{rr}51 & 32 \\ 61 & 18 \\ 15 & 9 \\ 26 & 11 \\ 4 & 6 \\ & \\ 11 & \\ 5 & 11 \\ 2 & 29 \\ 5 & 7 \\ & 0\end{array}$

Communicatie

$\begin{array}{lll}\text { Functioneringsgesprekken } & 73 & 17\end{array}$

Beoordelingsgesprekken $\quad 65 \quad 14$

$\begin{array}{lll}\text { Scholingsgesprekken } & 38 & 25\end{array}$

Geregeld werkoverleg $\quad 64 \quad 19$

Bron: ROA/Werkgeverspanel Metalektro 2004 



\section{$4 \quad$ Vacatures en de werving van personeel}

In dit hoofdstuk gaan we in op de vacatures in de Metalektro en het wervingsbeleid van de bedrijven. Hierbij gaat het om vragen als: Voor welke functies hadden de metalektrobedrijven in 2004 vacatures open staan? Hoe lang staan ze gemiddeld open? En hoe zijn de vacatures ontstaan? In het tweede gedeelte van het hoofdstuk vragen we ons af welke problemen bedrijven ondervinden bij de werving van nieuw personeel, wat ze concreet aan deze problemen proberen te doen en in hoeverre ze bij de werving van nieuw personeel concurrentie ondervinden van andere bedrijven. Ook gaan we in op de effectiviteit van verschillende wervingskanalen, de wervingsvoorkeuren van bedrijven en in hoeverre bedrijven samenwerken met andere bedrijven om personeelsflexibiliteit te realiseren. In de slotparagraaf wordt ingegaan op het stagebeleid van de metalektrobedrijven en de wijze waarop de bedrijven samenwerken met onderwijsinstellingen.

\subsection{Vacatures}

De ontwikkelingen in de afgelopen drie jaar

Figuur 4.1 geeft een overzicht van de ontwikkeling van het totaal aantal vacatures in de Metalektro van de afgelopen drie jaar. In de periode van het begin van 2002 tot medio 2003 daalde het totaal aantal vacatures van rond de 6.000 naar minder dan

Figuur 4.1

Ontwikkeling van het totaal aantal vacatures in de Metalektro, 2002-2004, per 4 maanden

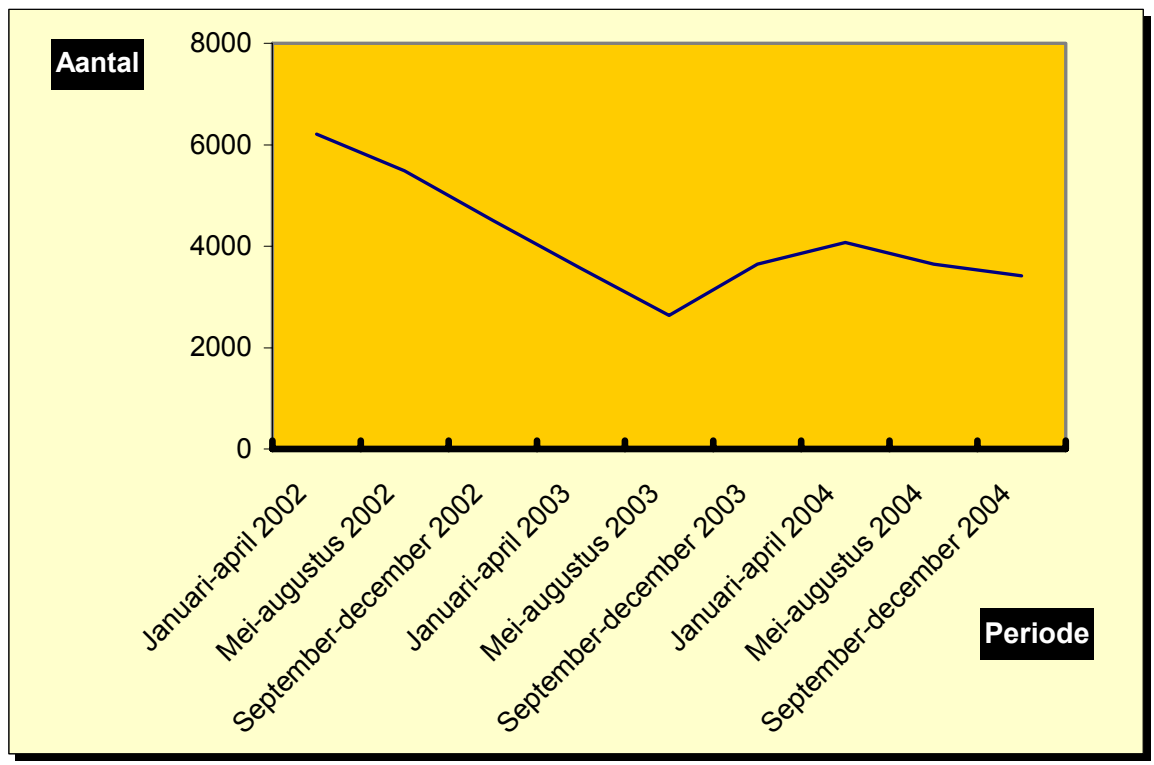

Noot: De cijfers voor 2002 en 2003 zijn herschaald op perioden van 4 maanden.

Bron: ROA/Werkgeverspanel Metalektro 2002, 2003, 2004 
3.000. In de daarop volgende maanden was er een bescheiden stijging van het aantal vacatures tot circa 4.000. In 2004 was er sprake van een lichte daling van het totaal aantal vacatures.

\section{Aantal vacatures naar functiecategorie in 2004}

Voor welke soort functies hadden de Metalektrobedrijven in 2004 vacatures? Figuur 4.2 geeft aan dat er over het gehele jaar gezien alleen sprake was van een stijgend aantal vacatures voor hogere managementfuncties en leidinggevende technische functies. Voor uitvoerende technische functies en functies waarbij ontwikkeling en engineering centraal staat daalde het aantal vacatures aanzienlijk. Het aantal vacatures voor ondersteunende functies bleef gedurende het jaar 2004 ongeveer gelijk.

Figuur 4.2

Aantal openstaande vacatures per functiecategorie per vier maanden in 2004

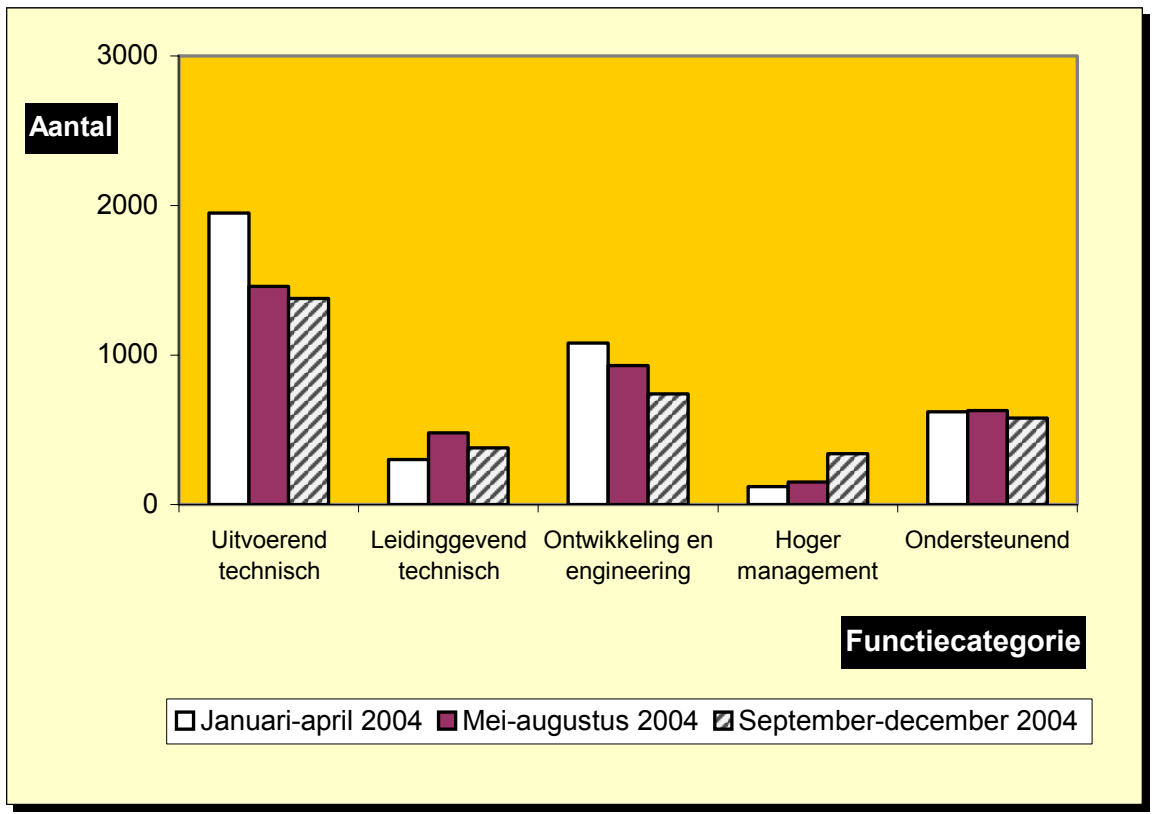

Bron: ROA/Werkgeverspanel Metalektro 2004

\section{Duur van openstaande vacatures}

Hoe lang staan de vacatures in de Metalektro gemiddeld open? Tabel 4.1 laat zien dat de meeste vacatures voor technisch personeel (82\%) in april 2004 minder dan 3 maanden openstonden. $16 \%$ van de vacatures stonden op dat moment tussen de drie en zes maanden open. Het aandeel van kortdurende vacatures in het totaal aantal vacatures voor technisch personeel is in de loop van 2004 echter gedaald. In december 2004 stonden nog gemiddeld circa zes van de tien vacatures korter dan 3 maanden open. Bij een kwart van de vacatures aan het eind van 2004 ging het om vacatures die meer dan 3 maanden maar minder dan een half jaar openstonden. 
$12 \%$ van de vacatures stond in december 2004 langer dan 6 maanden open. De daling van het aantal kortdurende vacatures duidt erop dat het voor de metalektrobedrijven in de loop van 2004 weer iets moeilijker is geworden om hun vacatures snel in te vullen. Uit achterliggende gegevens blijkt dat de verschillen tussen de regio's wat betreft de duur van openstaande vacatures gering zijn. Wel is er in de regio Noord/Oost iets vaker sprake van vacatures die langer dan 3 maanden openstaan.

Tabel 4.1

Vacatures voor technische werknemers, naar het aantal maanden dat ze openstaan, 2004

\begin{tabular}{lrr}
\hline Duur openstaande vacatures & $\begin{array}{r}\text { april } 2004 \\
\%\end{array}$ & $\begin{array}{r}\text { december } 2004 \\
\%\end{array}$ \\
& & 64 \\
Korter dan 3 maanden & 82 & 24 \\
3 tot 6 maanden & 16 & 7 \\
6 tot 12 maanden & 1 & 5
\end{tabular}

Bron: ROA/Werkgeverspanel Metalektro 2004

Uit de gesprekken met deelnemers aan het Werkgeverspanel blijkt dat de meeste bedrijven hun vacatures momenteel goed kunnen invullen. Een personeelsmanager van een groot metalektrobedrijf: "Het lukt ons momenteel redelijk goed om het benodigde personeel binnen te halen. We hebben wel eens vacatures die langer openstaan, maar dan gaat het meestal om hoogopgeleid personeel. Dat we het qua werving goed doen heeft er ook mee te maken dat we bekend staan als een goede werkgever. Dat blijkt ook uit het aantal spontane sollicitatiebrieven dat we binnen krijgen". Ook andere bedrijven geven aan dat de personeelswerving momenteel weinig problemen oplevert: "In het algemeen lukt het werven van personeel goed. We hebben maar één keer lang naar een projectengineer moeten zoeken". De bedrijven verwachten wél dat de werving van technisch personeel in de toekomst moeilijker zal worden. Verschillende bedrijven verwachten een tekort aan hoogopgeleide werknemers wanneer de economie de komende jaren weer aantrekt. Ook de middelgrote bedrijven hebben doorgaans een goed beeld van de te verwachten arbeidsmarktontwikkelingen: "De vraag zal toenemen, er zal sprake zijn van een grote uitstroom van 'baby boomers' en het aanbod van schoolverlaters zal afnemen".

\section{Ontstaan van vacatures}

Waardoor ontstaan vacatures? Aan de bedrijven is in 2004 op twee momenten gevraagd waardoor hun vacatures voor technisch personeel zijn ontstaan. Tabel 4.2 geeft daarvan een overzicht. De belangrijkste redenen voor het ontstaan van vacatures zijn de groei van het bedrijf of een toename van de hoeveelheid werk of het vertrekken van personeel. Achterliggende cijfers laten zien dat vooral bedrijven in de regio Zuid relatief vaak aangeven dat ze vacatures hebben omdat het bedrijf groeit of omdat de hoeveelheid werk toeneemt. De andere mogelijke redenen voor het ontstaan van vacatures zijn slechts voor een beperkt aantal bedrijven relevant. 
Zo geven vrijwel geen bedrijven aan dat er vacatures ontstaan doordat andere werknemers minder zijn gaan werken of door (langdurige) ziekte van werknemers of doordat bepaalde werknemers tijdelijk niet inzetbaar zijn.

Tabel 4.2

Vacatures voor technische werknemers naar reden van ontstaan, 2004 (\% bedrijven)

\begin{tabular}{lrr} 
Reden van ontstaan & April 2004 & December 2004 \\
& $\%$ & $\%$ \\
\hline & & 56 \\
Groei bedrijf / toename hoeveelheid werk & 59 & 53 \\
Personeel vertrokken & 60 & 2 \\
Andere werknemers zijn minder gaan werken & 0 & 4 \\
(Langdurige) ziekte van werknemers & 6 & 1 \\
Andere werknemers zijn tijdelijk niet inzetbaar & 0 & 20 \\
Anders & 13 &
\end{tabular}

Noot: De verschillende percentages staan los van elkaar en hoeven dus niet op te tellen tot $100 \%$.

Bron: ROA/Werkgeverspanel Metalektro 2004

\section{Verwachte ontwikkeling aantal vacatures}

Hoe zal het aantal vacatures voor technisch personeel zich ontwikkelen? In het begin van 2004 is aan de bedrijven gevraagd wat op dit punt hun verwachtingen zijn voor 2005. Figuur 4.3 geeft aan dat ongeveer de helft van de bedrijven verwacht dat het aantal vacatures (ongeveer) gelijk zal blijven. Daarentegen verwacht $15 \%$ van de bedrijven een toename van het aantal vacatures, terwijl één op de vijf bedrijven verwacht dat het aantal vacatures zal dalen. Ongeveer eenzelfde gedeelte heeft moeite met het inschatten van de verwachte ontwikkelingen in het aantal vacatures. Per saldo zijn er dus wat meer bedrijven die verwachten dat het aantal vacatures voor technisch personeel in 2005 op een lager niveau ligt dan bedrijven die een toename van het aantal vacatures verwachten.

\section{Figuur 4.3}

Verwacht aantal openstaande vacatures voor technisch personeel in 2005 (\% bedrijven)

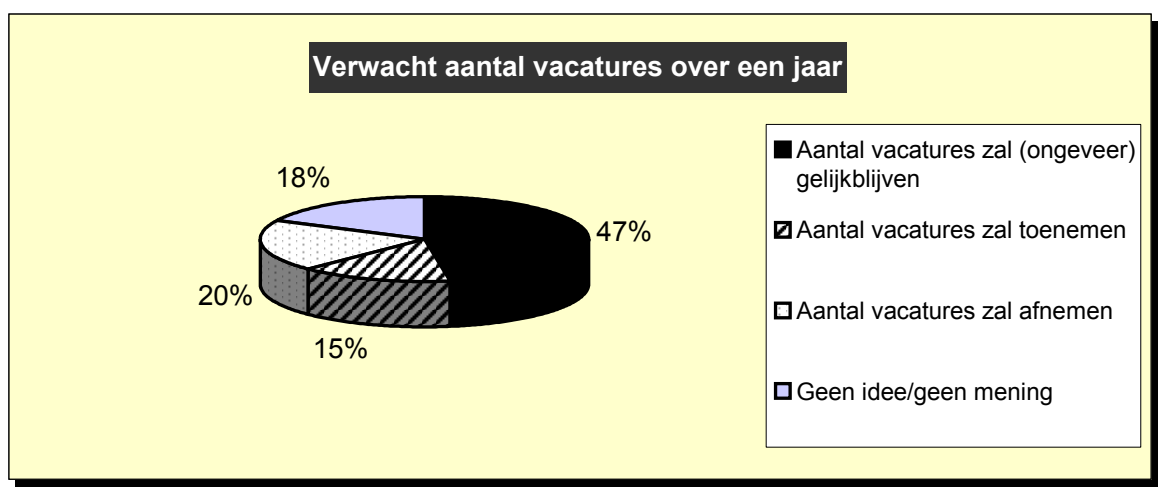

Bron: ROA/Werkgeverspanel Metalektro 2004 
Waarom verwachten de bedrijven een toe- of afname van het aantal vacatures? $\mathrm{Bij}$ de bedrijven die een toename verwachten denkt circa één derde dat dit komt door de vergrijzing van het personeelsbestand. Ruim vier op de tien bedrijven verwachten dat het verbeteren van de economische situatie tot een toename van het aantal vacatures zal leiden. Van de bedrijven die een afname van het aantal vacatures verwachten denkt meer dan de helft dat dit komt doordat het bedrijf zal krimpen, of de hoeveelheid werk zal afnemen. Circa één op de vijf bedrijven verklaart het afnemende aantal vacatures doordat de personeelsuitstroom zal verminderen.

\subsection{Wie zoekt die vindt?}

Onder invloed van de economische teruggang van de afgelopen jaren is het op de korte termijn makkelijk om personeel te werven, eenvoudigweg doordat het aanbod van arbeidskrachten gestegen is. Tabel 4.3 laat zien dat de afgelopen jaren steeds minder bedrijven problemen hadden met het aantrekken van technisch personeel. In 2002 gaf nog bijna één op de vijf bedrijven aan dat er (erg) veel problemen waren bij het vinden van technisch personeel. In 2004 was dat gedaald tot $6 \%$ van de metalektrobedrijven. De grote meerderheid van de bedrijven heeft momenteel weinig of geen problemen bij het vinden van technisch personeel. Dit beeld zou op de wat langere termijn wel kunnen veranderen, wanneer er door uitstroom als gevolg van (pré-)pensionering weer meer vraag komt naar technisch geschoolde werknemers.

Tabel 4.3

Problemen bij het vinden van technisch personeel, 2002-2004 (\% bedrijven)

\begin{tabular}{lrrr}
\hline Beoordeling & $\begin{array}{r}2002 \\
\%\end{array}$ & $\begin{array}{r}2003 \\
\%\end{array}$ & $\begin{array}{r}2004 \\
\%\end{array}$ \\
\hline Erg veel problemen & 5 & 2 & 1 \\
Veel problemen & 14 & 7 & 5 \\
Gemiddelde problemen & 22 & 18 & 14 \\
Weinig problemen & 24 & 34 & 24 \\
Erg weinig problemen & 9 & 6 & 10 \\
Geen problemen & 27 & 33 & 46
\end{tabular}

Bron: ROA/Werkgeverspanel Metalektro 2002-2004

Wat zijn nu de problemen waarmee de bedrijven kampen bij het vervullen van openstaande vacatures voor technisch personeel? Tabel 4.4 laat zien dat, evenals in vorige jaren, het belangrijkste probleem is dat de sollicitanten niet de juiste kwalificaties hebben. Ook vinden bijna zes van de tien bedrijven die problemen hebben met het vervullen van hun vacatures dat de sollicitanten onvoldoende werkervaring hebben. $42 \%$ vindt het aanbod van schoolverlaters te klein. Ongeveer een kwart van de bedrijven met problemen vindt dat de salariseisen van de sollicitanten te hoog zijn. Dat is veel minder dan in 2003 , toen nog bijna de helft van de bedrijven vond dat sollicitanten te hoge looneisen stelden. Ook het percentage bedrijven dat vindt dat sollicitanten te hoge 'andere eisen' stellen is ten opzichte van 2003 gedaald. Dat geeft aan dat kandidaat-werknemers onder invloed van de minder goede economische omstandigheden momenteel veel minder geneigd zijn om te hoge 
eisen te stellen wanneer ze solliciteren voor een baan in een metalektrobedrijf, dan in de voorgaande jaren.

Tabel 4.4

Belangrijkste problemen bij het vervullen van openstaande vacatures voor technisch personeel, 2004 (\% bedrijven)

Beoordeling

Te weinig aanbod vanuit opleidingen

Te weinig aanbod van sollicitanten met voldoende werkervaring 58

Te weinig aanbod van sollicitanten met de juiste kwalificaties $\quad 75$

Te hoge salariseisen van sollicitanten

Te hoge andere eisen van sollicitanten

Concurrentie van andere bedrijven binnen de Metalektro

Concurrentie van andere bedrijven buiten de Metalektro

Anders

Noot: De verschillende percentages staan los van elkaar en hoeven dus niet op te tellen tot $100 \%$.

Bron: ROA/Werkgeverspanel Metalektro 2004

\subsection{Het beleid bij wervingsproblemen}

Hoe gaan de metalektrobedrijven om met moeilijkheden bij de werving van technisch personeel? Bedrijven kunnen daar op verschillende manieren op inspelen. Tabel 4.5 geeft een overzicht van interne aanpassingen waartoe de bedrijven de afgelopen jaren zijn overgegaan wanneer ze kampen met moeilijk vervulbare vacatures voor technisch personeel.

Tabel 4.5

Interne aanpassingen bij moeilijk vervulbare vacatures voor technisch personeel, 2002-2004 (\% bedrijven)

Interne aanpassingen

Om- of bijscholen van huidige werknemers

Overwerk

$\begin{array}{lll}40 & 31 & 59\end{array}$

Breder inzetten van huidige werknemers

Uitbesteden van werk binnenland

Uitbesteden van werk buitenland

Automatiseren

Productie beperken

Noot: De verschillende percentages staan los van elkaar en hoeven dus niet op te tellen tot $100 \%$.

Bron: ROA/Werkgeverspanel Metalektro 2004

In het algemeen blijkt dat er een duidelijke toename is van het aantal bedrijven dat bepaalde interne maatregelen neemt als reactie op moeilijk vervulbare vacatures. Dat wijst er op dat steeds meer metalektrobedrijven verschillende alternatieven inzetten om met deze problematiek om te gaan. Het laten overwerken of het om- of bijscholen van het huidige personeel zijn de meest voorkomende interne maatre46 
gelen waartoe bedrijven overgaan bij moeilijk vervulbare vacatures voor technisch personeel. Ook gaan veel bedrijven dan over tot het breder inzetten van het huidige personeel. Zeer opvallend is dat bedrijven in 2004 veel vaker werk uitbesteden dan in de jaren ervoor. Hierbij gaat het zowel om het uitbesteden van werk aan andere Nederlandse bedrijven als om het uitbesteden van werk aan buitenlandse bedrijven. Ook hebben in 2004 meer bedrijven bij moeilijk vervulbare vacatures hun productieproces verder geautomatiseerd. In totaal is ruim één vijfde van de metalektrobedrijven hiertoe overgegaan.

Naast interne aanpassingen kunnen bedrijven bij moeilijk vervulbare vacatures voor technisch personeel natuurlijk ook hun wervings- en selectiebeleid veranderen. Uit tabel 4.6 blijkt dat in 2004 meer bedrijven als reactie op moeilijk vervulbare vacatures hun wervings- en selectiebeleid hebben aangepast. Opvallend is dat meer dan zeven van de tien bedrijven met moeilijk vervulbare vacatures een uitzendbureau of ander commercieel wervings- en selectiebureau inschakelen. Het percentage bedrijven dat dit doet is in vergelijking met vorige jaren aanzienlijk gestegen. Een bedrijf uit de transportmiddelensector gaf tijdens een interview aan dat deze manier van werven het bedrijf veel werk uit handen neemt: "Het uitzendbureau selecteert mogelijk geschikte kandidaten, waarvan er dan meestal enkele bij ons in dienst komen. $\mathrm{Na}$ een jaarcontract komen die mensen dan meestal bij ons vast in dienst". Verder blijkt dat ook veel bedrijven met moeilijk vervulbare vacatures er toe over gaan om mensen met minder ervaring aan te trekken. Het percentage bedrijven dat dit doet is in 2004 sterk gestegen. Ook blijkt dat steeds meer bedrijven met moeilijk vervulbare vacatures actief scholieren benaderen. Een andere opvallende uitkomst is dat de metalektrobedrijven in 2004 minder vaak inspelen op moeilijk vervulbare vacatures door een hoger salaris te bieden of door lager opgeleiden aan te nemen.

Tabel 4.6

Aanpassingen in werving en selectie bij moeilijk vervulbare vacatures voor technisch personeel, 2004 (\% bedrijven)

Aanpassingen in werving en selectie

$2002 \quad 2003-2004$

\begin{tabular}{lll}
$\%$ & $\%$ \\
\hline
\end{tabular}

Inschakelen uitzendbureaus/commerciële werving en selectiebureaus $\quad 56 \quad 41 \quad 71$

$\begin{array}{llll}\text { Aantrekken van mensen met minder ervaring } & 39 & 26 & 55\end{array}$

Inschakelen CWI (Arbeidsbureau) $\quad 13 \quad 14 \quad 24$

Actiever benaderen van scholieren $\quad 32 \quad \begin{array}{lll}15 & 23\end{array}$

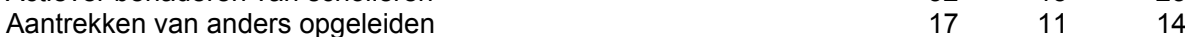

Bieden van betere, CAO overstijgende arbeidsvoorwaarden $\quad 8 \quad 4 \quad 4 \quad 9$

Aantrekken van lager opgeleiden $\quad 20 \quad 15 \quad 5$

Bieden van hoger salaris $\quad 11 \quad 3 \quad 5$

$\begin{array}{llll}\text { Geen aanpassingen in werving en selectie } & 30 & 47 & 14\end{array}$

Noot: De verschillende percentages staan los van elkaar en hoeven dus niet op te tellen tot $100 \%$.

Bron: $\quad$ ROA/Werkgeverspanel Metalektro 2004 
De toename van het aantal bedrijven dat vanwege moeilijk vervulbare vacatures hun wervings- en selectiebeleid heeft aangepast en interne aanpassingen doorvoert, geeft aan dat de afname van de wervingsproblematiek in de metalektrosector niet alleen het gevolg is van de ruimere arbeidsmarkt voor technisch opgeleiden. Ook de toegenomen professionaliteit van het HRM-beleid in veel bedrijven heeft hiertoe zeker bijgedragen.

\section{Concurrentie bij de werving}

In hoeverre speelt de concurrentie met andere bedrijven een rol bij de werving van technisch personeel? Tabel 4.7 laat zien dat slechts een klein gedeelte van de bedrijven (zeer) veel concurrentie ervaart. 35\% van de metalektrobedrijven ervaart enige concurrentie met andere metalektrobedrijven in de eigen regio, terwijl $19 \%$ van de metalektrobedrijven binnen de eigen regio concurrentie ondervindt van nietmetalektrobedrijven. Daarentegen ondervindt slechts $11 \%$ van de bedrijven op de arbeidsmarkt enige concurrentie van niet-metalektrobedrijven buiten de eigen regio. Tijdens de gesprekken met bedrijven die deelnemen aan het Werkgeverspanel Metalektro bleek dat sommige bedrijven toch wel degelijk concurrentie ervaren. Een personeelsmanager: "Om een hoger opgeleide technicus aan te nemen moet je ze bijna wegkopen bij de concurrentie".

Tabel 4.7

Concurrentie bij de werving van technisch personeel, 2004 (\% bedrijven)

\begin{tabular}{|c|c|c|c|c|}
\hline Concurrentie & $\begin{array}{r}\text { Metalektro } \\
\text { in de } \\
\text { regio } \\
\%\end{array}$ & $\begin{array}{r}\text { Metalektro } \\
\text { buiten de } \\
\text { regio } \\
\%\end{array}$ & $\begin{array}{r}\text { Niet-Metalektro } \\
\text { in de } \\
\text { regio } \\
\%\end{array}$ & $\begin{array}{r}\text { Niet-Metalektro } \\
\text { buiten de } \\
\text { regio } \\
\%\end{array}$ \\
\hline (Zeer) veel concurrentie & 3 & 1 & 4 & 1 \\
\hline Niet veel/niet weinig concurrentie & 35 & 19 & 17 & 11 \\
\hline Weinig of geen concurrentie & 40 & 52 & 48 & 50 \\
\hline Weet niet /geen mening & 21 & 29 & 32 & 38 \\
\hline
\end{tabular}

Bron: ROA/Werkgeverspanel Metalektro 2004

Hoewel relatief weinig bedrijven aangeven bij de personeelswerving concurrentie te ondervinden van niet-metalektrobedrijven, is het wel van belang om te weten met welke soort bedrijven er dan wordt geconcurreerd. Tabel 4.8 laat zien dat het vooral gaat om bedrijven uit de kleinmetaal. In mindere mate is er sprake van concurrentie met chemiebedrijven. Daarnaast ondervinden de metalektrobedrijven op de arbeidsmarkt nog enige concurrentie van de zakelijke dienstverlening, de ICT-sector en de bouwsector. Voor de overige bedrijfssectoren is de concurrentie met de Metalektro beperkt. 
Tabel 4.8

Sectoren waarmee de Metalektro op de arbeidsmarkt concurreert, 2004 (\% bedrijven)

Concurrerende sector

Kleinmetaal $\quad 74$

$\begin{array}{lr}\text { Chemie } & 23\end{array}$

Zakelijke dienstverlening / ICT 13

Bouw $\quad 10$

\begin{tabular}{lr} 
Hout- en bouwmaterialen industrie & 7 \\
\hline
\end{tabular}

Handel

Textiel industrie $\quad 3$

Papier industrie $\quad 3$

Overheid en onderwijs $\quad 3$

Grafische industrie $\quad 0$

Energie sector

$\begin{array}{lr}\text { Transport en communicatie } & 0\end{array}$

$\begin{array}{lr}\text { Anders } & 19\end{array}$

Noot: De verschillende percentages staan los van elkaar en hoeven dus niet op te tellen tot $100 \%$.

Bron: $\quad$ ROA/Werkgeverspanel Metalektro 2004

Effectieve wervingskanalen

Op welke manieren kunnen de metalektrobedrijven nu het meest effectief hun personeel werven? Tabel 4.9 geeft daarvan voor zowel het uitvoerend als het leidinggevend technisch personeel een overzicht. Het blijkt dat voor het uitvoerend technisch personeel het werven via een uitzendbureau of door middel van een advertentie in een regionaal dagblad het meest effectief wordt gevonden. Daarnaast geeft $11 \%$ van de bedrijven aan dat ze uitvoerend technisch personeel ook effectief kunnen werven via het personeel dat al werkzaam is bij het bedrijf. Voor het werven van leidinggevend technisch personeel blijkt een advertentie in een regionaal dagblad het meest effectieve wervingskanaal. Op de tweede plaats komt het werven via een commercieel wervingsbureau. Zowel voor uitvoerend als leidinggevend technisch personeel blijft de effectiviteit van het CWI als wervingskanaal zeer beperkt. Slechts $1 \%$ van de bedrijven geeft aan dit een effectief wervingskanaal te vinden. Ook het werven via de opleiding of de school van schoolverlaters wordt door weinig bedrijven als effectief ervaren. Opvallend is dat het gebruik van het internet belangrijker is geworden bij het werven van technisch personeel. Het aantal bedrijven dat aangeeft dat dit wervingskanaal effectief is, is in 2004 verdubbeld ten opzichte van het jaar ervoor. Met name voor de werving van leidinggevend technisch personeel geven betrekkelijk veel bedrijven aan dat het internet een effectief wervingskanaal is. 
Tabel 4.9

Meest effectieve wervingskanalen voor uitvoerend en leidinggevend technisch personeel, 2004 (\% bedrijven)

Wervingskanaal Uitvoerend technisch Leidinggevend technisch personeel personeel $\%$

Eigen personeel in bedrijfsvestiging

Personeel in andere bedrijfsvestigingen

Externe relaties

Open sollicitaties

Advertentie in regionaal dagblad

Advertentie in landelijk dagblad

Advertentie in vakblad

Internet

Uitzendbureau

CWI (Arbeidsbureau)

School/opleiding

Commercieel wervingsbureau

Anders

$\begin{array}{rr}11 & 7 \\ 1 & 1 \\ 4 & 4 \\ 6 & 2 \\ 28 & 35 \\ 0 & 8 \\ 0 & 4 \\ 5 & 11 \\ 36 & 6 \\ 1 & 1 \\ 4 & 0 \\ 3 & 22 \\ 2 & 1\end{array}$

Bron: ROA/Werkgeverspanel Metalektro 2004

\section{Wervingsvoorkeuren}

Waar liggen de voorkeuren bij het werven van nieuw technisch personeel? Uit tabel 4.10 blijkt dat het aantal bedrijven dat een voorkeur heeft voor schoolverlaters met een relevant vakdiploma in 2004 iets is toegenomen. Toch geeft de overgrote meerderheid van de bedrijven (62\%) nog steeds aan dat ze het liefst werkenden of werkzoekenden met relevante werkervaring aantrekken. Hieruit blijkt duidelijk dat de metalektrobedrijven nog steeds veel waarde hechten aan het aantrekken van nieuw personeel met werkervaring.

Tabel 4.10

Voorkeur bij het invullen van vacatures voor technisch personeel (\% bedrijven)

\begin{tabular}{|c|c|c|}
\hline Voorkeur & 2003 & 2004 \\
\hline & $\%$ & $\%$ \\
\hline Schoolverlater met relevant vakdiploma & 12 & 17 \\
\hline Werkende/werkzoekende met relevante werkervaring & 65 & 62 \\
\hline Geen voorkeur & 24 & 21 \\
\hline
\end{tabular}

Bron: ROA/Werkgeverspanel Metalektro 2003-2004

Ook uit de gesprekken met deelnemers aan het Werkgeverspanel Metalektro blijkt duidelijk de voorkeur voor personeel met werkervaring. Een HRM-manager van een bedrijf met veel productiepersoneel: "Het is ook logisch dat er een grote voorkeur voor mensen met werkervaring bestaat. Van die mensen kan verwacht worden dat ze eraan gewend zijn om in een industriële omgeving te werken. Bij schoolverlaters 
is dat veel moeilijker te beoordelen. Voor deze groep is het vaak behoorlijk wennen aan het zware werk".

Dat veel bedrijven bij de werving van nieuw personeel een voorkeur hebben voor mensen met werkervaring, betekent echter niet dat er helemaal geen aandacht is voor schoolverlaters. Enkele bedrijven gaven aan dat ze graag werken met een "mix" van mensen met werkervaring en schoolverlaters. Een personeelsfunctionaris: "We werken met beide soorten personeel, en dat vooral uit kostenoogpunt. Ervaring is van belang maar het kost ook veel meer. Door ook schoolverlaters in dienst te nemen kunnen we komen tot een betere kostenstructuur in onze projecten". Enkele andere bedrijven benadrukken dat het ook erg afhangt van de soorten functies en afdelingen waarvoor mensen worden gezocht: "Voor functies op VMBO-niveau vragen we altijd werkervaring. Bij MBO-functies nemen we ook personeel zonder eerdere werkervaring aan". Een ander bedrijf: "Op kleinere afdelingen zoekt de manager vaker naar mensen met werkervaring, omdat het daar sterk van belang is dat het nieuwe personeel direct productief kan worden ingezet".

\section{Samenwerking met andere bedrijven}

Het is bekend dat de behoefte aan nieuw personeel niet altijd hoeft te leiden tot het in dienst nemen van nieuwe werknemers. Vooral wanneer bedrijven een bepaalde flexibiliteit in hun personeelsinzet nodig hebben, wordt, zoals we in hoofdstuk 2 zagen vaak gebruik gemaakt van een uitzendbureau. Een interessante ontwikkeling is ook dat bedrijven, meestal op regionaal niveau, met elkaar samenwerken om een bepaalde personeelsflexibiliteit te realiseren. Uit de gesprekken met deelnemers van

\section{Figuur 4.4}

Samenwerking met andere bedrijven in de regio om de behoefte aan flexibiliteit van het technisch personeel op te vangen, 2004 (\% bedrijven)

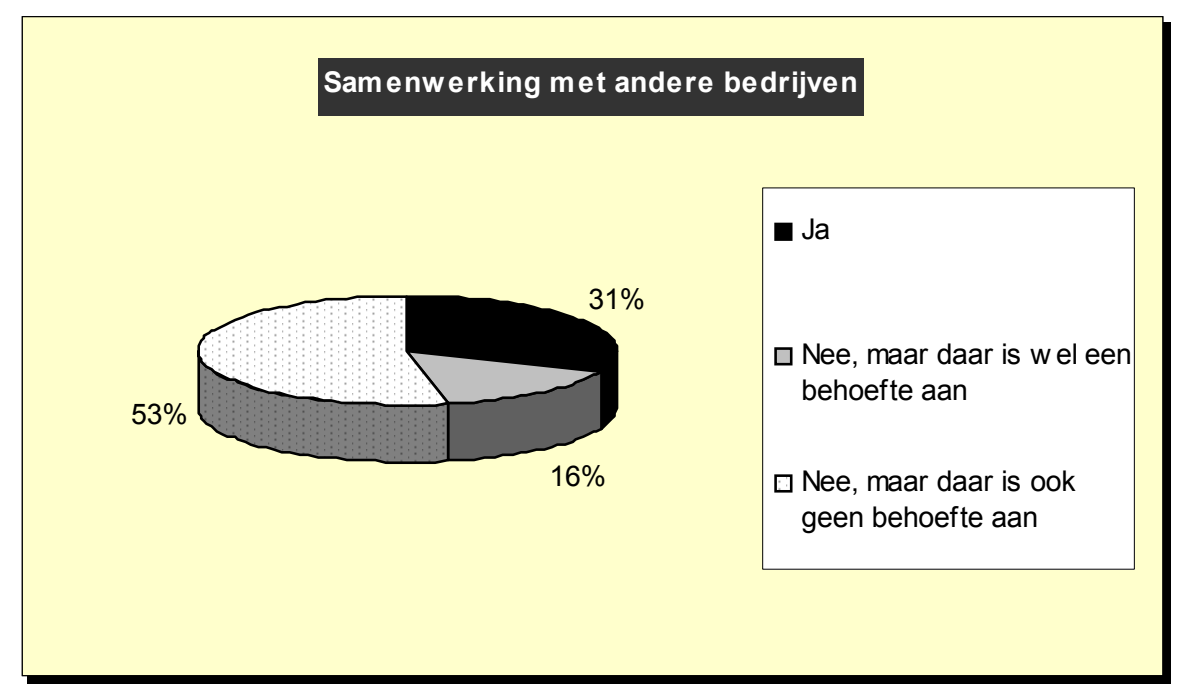

Bron: ROA/Werkgeverspanel Metalektro 2004 
het Werkgeverspanel Metalektro bleek ook duidelijk dat een aantal bedrijven verwachten dat het belang van deze regionale samenwerking in de nabije toekomst alleen maar zal toenemen.

Figuur 4.4 laat zien dat bijna één op de drie bedrijven momenteel samenwerkt met andere bedrijven om een bepaalde personeelsflexibiliteit te realiseren. Hierbij kan men bijvoorbeeld denken aan het 'collegiaal inlenen' van personeel. 16\% van de bedrijven geeft aan momenteel nog niet samen te werken met andere bedrijven maar hier wel behoefte aan te hebben. Daarentegen werkt iets meer dan de helft van de bedrijven (nog) niet samen met collega-bedrijven en ziet men daar ook geen noodzaak toe.

De samenwerking met andere bedrijven in de regio om de benodigde personeelsflexibiliteit op te vangen kan verschillende vormen aannemen. Uit tabel 4.11 blijkt de samenwerking vooral betrekking te hebben op de collegiale in- en uitleen van personeel. Maar liefst $86 \%$ van de bedrijven die met elkaar samenwerken leent wel eens personeel van een collega-bedrijf in en ruim zeven van de tien bedrijven leent wel eens personeel uit. Het is opmerkelijk dat er minder bedrijven zijn die ook personeel uitlenen. Dit betekent dat $15 \%$ van de bedrijven voor andere bedrijven in hun regio een buffer vormen om pieken in de personeelsbehoefte op te kunnen vangen. Een minderheid van de metalektrobedrijven (16\%) werkt met andere bedrijven samen bij gezamenlijke wervingsacties.

Tabel 4.11

Manieren waarop er samengewerkt wordt met andere bedrijven in de regio om een flexibele inzet van het technisch personeel te realiseren, 2004 (\% bedrijven)

Manier

Bij een tijdelijk personeelstekort wordt er personeel van andere metalektrobedrijven ingeleend

Bij een tijdelijk personeelsoverschot wordt er personeel aan andere

metalektrobedrijven uitgeleend

Bij problemen bij de werving van technisch personeel wordt er met andere

metalektrobedrijven samengewerkt

Anders

Noot: $\quad$ De verschillende percentages staan los van elkaar en hoeven dus niet op te tellen tot $100 \%$.

Bron: $\quad$ ROA/Werkgeverspanel Metalektro 2004

\subsection{Haal kennis jong in huis!}

Omdat één van de belangrijkste toekomstige ontwikkelingen in de Metalektro de vergrijzing van het personeelsbestand is, is het van belang dat bedrijven daar nu al zoveel mogelijk op inspelen. Een traditioneel belangrijke vorm om pro-actief in te spelen op de toekomstige personeelsbehoefte is het aanbieden van leer-arbeidsovereenkomsten aan leerlingen uit het BBL of het aantrekken van stagairs uit het hoger onderwijs. Deze jonge werknemers kunnen nadat ze hun opleiding of stage voltooid hebben eventueel in dienst worden genomen van het bedrijf. 
Tabel 4.12 geeft een overzicht van het aantal leerlingen uit de BBL met een leerarbeidsovereenkomst en het aantal stagairs met een technische HBO of universitaire opleiding. In de metalektrobedrijven waren er in 2004 in totaal 1.300 BBL leerlingen $\left(1^{\mathrm{e}}\right.$ en $2^{\mathrm{e}}$ jaars) met een leer-arbeidsovereenkomst in dienst. Uit achterliggende gegevens blijkt dat ruim de helft van deze BBL leerlingen in 2004 met financiering van de Stichting $\mathrm{A}+\mathrm{O}$ in dienst is genomen. Het aantal leerlingen van de $\mathrm{BOL}$ dat in 2004 met ondersteuning van de Stichting $A+O$ een stage begon bedraagt 670 . Het is opmerkelijk dat het aantal stagiairs van technische HBO of universitaire opleidingen bijna even groot is als het aantal BBL'ers en BOL-stagiairs: 1.750. Dit illustreert de verschuiving in de vraag van middelbaar naar hoger opgeleide technici in veel metalektrobedrijven.

Tabel 4.12

Aantal leerlingen met leer-arbeidsovereenkomsten in het kader van de BBL en aantal stagiairs van technische $\mathrm{BOL}$ en $\mathrm{HBO} /$ universitaire opleidingen, 2004

Stagiairs/BBL leerlingen aantal

BBL-Leerlingen met een leer-arbeidsovereenkomst

waarvan: begonnen in 2004 met financiering van de Stichting A+O 690

Stagiairs van BOL begonnen in 2004 met financiering van de Stichting A+O 670

Stagiairs van HBO/Universiteit $\quad 1.750$

Bron: ROA/Werkgeverspanel Metalektro 2004 en Stichting A+O

Waarom bieden bedrijven leer-arbeidsovereenkomsten aan? Om daar een antwoord op te krijgen is er aan de bedrijven een drietal stellingen voorgelegd. Uit tabel 4.13 blijkt dat leer-arbeidsovereenkomsten vooral worden aangeboden omdat de competenties van werknemers die in het eigen bedrijf geschoold zijn beter aansluiten op de behoeften van het bedrijf dan de kennis en vaardigheden van werknemers die elders geschoold zijn. Dit argument speelt bij maar liefst $83 \%$ van de metalektrobedrijven. Deze bedrijven zien er dus een groot voordeel in om BBL'ers voor een gedeelte bedrijfsspecifieke kennis mee te geven die belangrijk is voor hun verdere loopbaan bij het bedrijf. Verder geven bijna vier van de tien bedrijven aan dat werknemers die in het eigen bedrijf geschoold zijn een kortere inwerktijd hebben. Ook hier speelt waarschijnlijk een rol dat BBL'ers met leer-arbeidsovereenkomsten bepaalde bedrijfsspecifieke kennis en vaardigheden aanleren die ervoor zorgen dat als ze na hun opleiding bij het bedrijf in dienst treden, ze sneller volledig vakbekwaam aan de slag kunnen. Tenslotte geeft $29 \%$ van de bedrijven aan dat de BBL-functies als voordeel hebben dat men een goed beeld heeft van de competenties waarover deze mensen na hun opleiding beschikken.

Alle bedrijven waarmee gesprekken gevoerd zijn hebben BBL-leerlingen en/of stagiairs in dienst. Naast het feit dat deze jonge werknemers vanzelfsprekend bijdragen aan het productieproces, hebben de bedrijven ook verschillende andere redenen om ze in dienst te nemen. Vaak gaat het eenvoudigweg om het later zelf in vaste dienst kunnen nemen van deze werknemers. Een personeelsmanager van een bedrijf dat op jaarbasis circa 40 BBL-ers in dienst heeft: "Het principe is dat deze mensen na hun opleiding in vaste dienst worden genomen. Vroeger was dat wat anders. Toen 
merkten we vaak dat de kennis en vaardigheden van de BBL-ers die de opleiding voltooid hadden nog niet volledig aansloten op onze wensen, waardoor we ze lang niet altijd in dienst namen. Daarom zijn we er toe over gegaan om meer zelf op te leiden. Dat heeft duidelijk resultaat. Nu wordt de helft van onze BBL-ers uiteindelijk vast personeel". Een bedrijf dat zowel BBL-leerlingen als stagiairs in dienst heeft: "Vanwege een vacaturestop kunnen we onze eigen BBL-ers niet meer in vaste dienst nemen. Maar als er goede tussen zitten proberen we ze wel onder te brengen bij een detacheringsbureau, zodat we ze vervolgens zelf kunnen inlenen. Stagiairs hebben we om twee redenen in dienst: we willen ze een kans bieden om een afstudeeropdracht te doen en het zijn misschien wel onze toekomstige medewerkers".

Tabel 4.13

Redenen voor het aanbieden van leer-arbeidsovereenkomsten, 2004 (\% bedrijven)

Redenen

Kennis en vaardigheden sluiten beter aan op de behoeften van het bedrijf

Kortere inwerktijd

Bedrijf weet meer over wat ze hebben geleerd

Noot: De verschillende percentages staan los van elkaar en hoeven dus niet op te tellen tot $100 \%$.

Bron: $\quad$ ROA/Werkgeverspanel Metalektro 2004

Naast het belang van het later zelf in dienst kunnen nemen van de BBL-ers of stagiairs, zijn er nog andere redenen om deze mensen in het bedrijf te laten werken. Meerdere bedrijven gaven aan dat ze het hun "maatschappelijke verantwoordelijkheid" of "morele plicht" vinden om zorg te dragen voor een gedeelte van de opleiding van jonge vakkrachten. Een andere reden is het contact met de scholen: "Op die manier is het makkelijker om bepaalde zaken efficiënt en snel met de scholen te kunnen regelen".

\section{Samenwerking met onderwijsinstellingen}

Voor het opleiden van stagiairs of BBL'ers is het belangrijk dat er goed met de onderwijsinstellingen wordt samengewerkt. Zoals figuur 4.5 laat zien gebeurt dat al uitgebreid in de Metalektro. Maar liefst acht op de tien bedrijven geeft aan dat ze samenwerken met onderwijsinstellingen in de regio. $5 \%$ van de bedrijven zegt dit nog niet te doen, maar er wel behoefte aan te hebben. Slechts $16 \%$ van de bedrijven werkt niet samen met onderwijsinstellingen in de regio en heeft daar ook geen behoefte aan.

Hoe wordt er dan samengewerkt met onderwijsinstellingen? Tabel 4.14 laat zien dat het in de meeste bedrijven gaat om samenwerking bij het aanbieden van stageplaatsen voor $\mathrm{BOL}$ (MBO) opleidingen en bij het afsluiten van leer-arbeidsovereenkomsten. De onderwijsinstellingen in de regio blijken ook een belangrijke rol te spelen bij het opzetten van cursussen voor het eigen personeel. Meer dan de helft van de bedrijven geeft aan in dit kader samen te werken met onderwijsinstellingen. $\mathrm{Bij} 41 \%$ van de bedrijven is de samenwerking met onderwijsinstellingen ook gericht 
op het vergroten van de belangstelling voor het technisch onderwijs, bijvoorbeeld door het organiseren van 'open dagen' voor scholieren van het technisch onderwijs, e.d. Gezien het imago-probleem waarmee het technisch onderwijs en de metalektrosector kampen, zou het wenselijk zijn als meer bedrijven op deze punten met onderwijsinstellingen zouden gaan samenwerken. Het is duidelijk dat de bedrijven die met onderwijsinstellingen samenwerken in de Metopia-projecten een soort voorhoede vormen van de metalektro-industrie. Toch participeert $11 \%$ van de bedrijven al in deze projecten.

Figuur 4.5

Samenwerking met onderwijsinstellingen in de regio, 2004 (\% bedrijven)

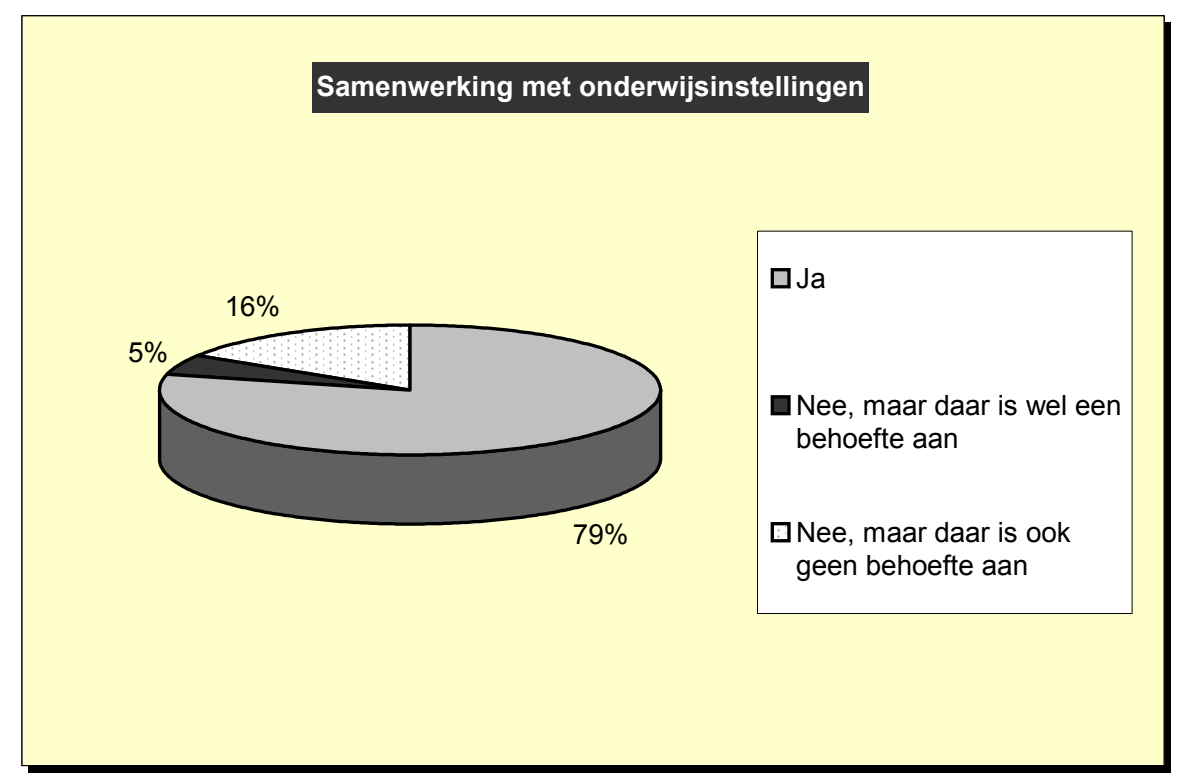

Bron: ROA/Werkgeverspanel Metalektro 2004

Tabel 4.14

Manieren waarop er samengewerkt wordt met onderwijsinstellingen in de regio, 2004 (\% bedrijven)

Manier

Bij het aanbieden van stageplaatsen voor BOL (MBO) opleidingen 86

Bij het in dienst nemen van BBL'ers (Leerlingwezen, leer-arbeidsovereenkomsten) $\quad 70$

Bij het opzetten van cursussen/opleidingstrajecten voor het eigen personeel 54

Bij het vergroten van de belangstelling voor het technisch onderwijs

In het kader van Metopia $\quad 11$

In het kader van EVC trajecten

Anders 12

Noot: De verschillende percentages staan los van elkaar en hoeven dus niet op te tellen tot $100 \%$.

Bron: ROA/Werkgeverspanel Metalektro 2004 



\section{$5 \quad$ Investeren in personeel: de sleutel tot succes?}

In dit hoofdstuk wordt aandacht besteed aan de scholing van het personeel in de Metalektro. Welke cursussen en trainingen worden door het technisch personeel gevolgd en hoe worden ze gefinancierd? Vervolgens wordt er gekeken naar de beweegredenen die bedrijven hebben om in hun personeel te investeren. Daarbij gaat het niet alleen om formele scholing maar kijken we ook naar andere manieren waarop de kennisverwerving plaats kan vinden. Ten slotte komt het HRM-beleid rond het investeren in het personeel aan bod en wordt een antwoord gegeven op de vraag welke HRM-instrumenten vooral worden ingezet om de kennisverwerving bij het personeel te bevorderen.

\subsection{Cursussen en trainingen: welke en wie betaalt?}

Verreweg de meeste bedrijven in de Metalektro bieden hun technisch personeel scholing aan. Zo laat tabel 5.1 zien dat in 2004 in $81 \%$ van de bedrijven interne cursussen gevolgd werden. Opvallend is dat er ten opzichte van de voorgaande twee jaren sprake is van een lichte stijging in het aantal bedrijven dat zelf cursussen voor het personeel organiseert. Daar staat tegenover dat er in 2004 per bedrijf wat minder technische werknemers (18\%) aan dergelijke cursussen hebben deelgenomen dan in $2003(22 \%)$. Het percentage bedrijven waar externe cursussen gevolgd worden is hoog: $84 \%$. In 2003 lag dit op hetzelfde niveau. Ook hier is het percentage technische medewerkers dat aan een externe cursus heeft deelgenomen gedaald, maar de daling is niet zo sterk als bij de deelname aan interne cursussen.

Tabel 5.1

Bedrijven en technisch personeel met interne en externe cursusparticipatie in 2002-2004

\begin{tabular}{|c|c|c|c|c|c|c|}
\hline \multirow[t]{2}{*}{ Cursusparticipatie } & \multicolumn{3}{|c|}{ Interne cursussen } & \multicolumn{3}{|c|}{ Externe cursussen } \\
\hline & $\begin{array}{c}2002 \\
\%\end{array}$ & $\begin{array}{c}2003 \\
\%\end{array}$ & $\begin{array}{c}2004 \\
\%\end{array}$ & $\begin{array}{c}2002 \\
\%\end{array}$ & $\begin{array}{c}2003 \\
\%\end{array}$ & $\begin{array}{c}2004 \\
\%\end{array}$ \\
\hline Bedrijven & 76 & 78 & 81 & 89 & 84 & 84 \\
\hline Technisch personeel $^{*}$ & 13 & 22 & 18 & 14 & 16 & 13 \\
\hline
\end{tabular}

* Het betreft hier het percentage technische werknemers dat cursussen volgt.

Bron: ROA/Werkgeverspanel Metalektro 2002-2004

Welke cursussen worden er vooral door technische medewerkers gevolgd? Uit figuur 5.1 blijkt dat vooral de cursussen op het gebied van de vaktechnische vaardigheden populair zijn. In $84 \%$ van de Metalektrobedrijven wordt door het technisch personeel - zowel intern als extern - aan deze cursussen deelgenomen. Uit gesprekken met de deelnemende bedrijven blijkt ook dat vakkennis op zich nog steeds erg belangrijk wordt gevonden, maar dat vooral de combinatie van verschillende soorten vakkennis steeds belangrijker wordt. Een personeelsmanager: "Het is van groot belang dat de mensen in voldoende mate beschikken over verschillende soorten vakkennis. Alleen op die manier kunnen we succesvol nieuwe markten betreden". 
Naast cursussen die gericht zijn op vakkennis worden er ook veel cursussen gevolgd op het gebied van veilig gedrag en cursussen gericht op het werken met de computer/IT. Deze cursussen worden opvallend vaak door het bedrijf zelf georganiseerd (respectievelijk in $45 \%$ en $39 \%$ van de bedrijven). Cursussen die vooral extern plaatsvinden zijn vaak gericht op leidinggeven ( $38 \%$ van de bedrijven) en plannen en organiseren (20\% van de bedrijven).

Figuur 5.1

Interne en externe cursusparticipatie van het technisch personeel, 2004 (\% bedrijven)

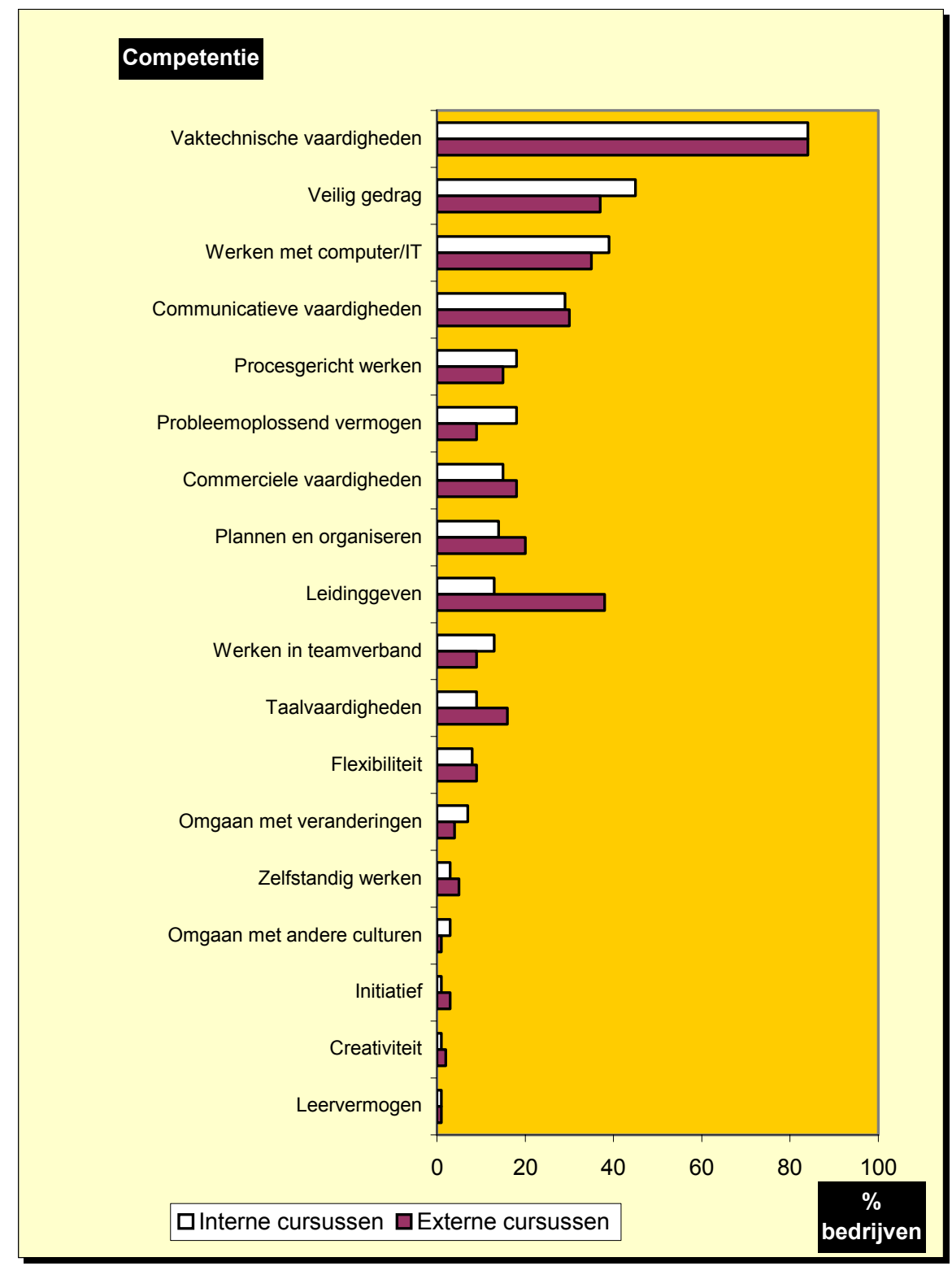

Bron: ROA/Werkgeverspanel Metalektro 2004 
Andere cursussen die relatief vaak gevolgd worden zijn cursussen in communicatieve vaardigheden, procesgericht werken en commerciële vaardigheden. In vergelijking met 2003, worden er in minder bedrijven cursussen gevolgd die gericht zijn op het vergroten van het probleemoplossend vermogen van het technisch personeel. Dit is opmerkelijk, omdat - zoals we in hoofdstuk 6 zullen zien - het de komende vijf jaren steeds belangrijker zal worden dat het technisch personeel over meer probleemvermogend vermogen gaat beschikken. In paragraaf 5.2 zal overigens blijken dat veel bedrijven het probleemoplossend vermogen van hun technisch personeel vooral via informele scholing en 'learning-by-doing' proberen te vergroten.

\section{Investeringspatronen}

Wie investeert er nu in de scholing van het technisch personeel in de Metalektro? Cursussen en trainingen brengen immers aanzienlijk kosten met zich mee. Het gaat daarbij niet alleen om de directe kosten van de cursussen zelf, maar ook om de tijd die werknemers aan scholing besteden, waardoor ze op dat moment niet productief kunnen zijn. Tabel 5.2 geeft aan dat 55\% van alle cursussen die door het technisch personeel gevolgd worden in de tijd van het bedrijf plaatsvindt, terwijl $21 \%$ van de scholing in de tijd van zowel de werknemer als het bedrijf plaatsvindt. Een kwart van de cursussen wordt door het technisch personeel in hun eigen (vrije) tijd gevolgd. In 2003 was dit overigens nog bij 32\% van de cursussen het geval. Uit deze cijfers blijkt dat meer metalektrobedrijven in 2004 tijd in scholing investeerden dan in 2003.

Tabel 5.2

Tijdsinvestering bij cursusdeelname door het technisch personeel, 2003 en 2004 (\% bedrijven)

\begin{tabular}{lcr}
\hline Cursussen worden gevolgd & 2003 & 2004 \\
& $\%$ & $\%$ \\
\hline In de tijd van het bedrijf & 51 & 55 \\
In de tijd van zowel de werknemer als het bedrijf & 17 & 21 \\
In de tijd van de werknemer & 32 & 24
\end{tabular}

Bron: ROA/Werkgeverspanel Metalektro 2004

Hoe zit het met de directe kosten van scholing? Tabel 5.3 laat zien dat de gemiddelde directe kosten voor scholing in 2004 bijna $€ 42.000$,- per bedrijf bedroegen. In 2003 lagen deze zogenaamde 'out of pocket' kosten met $€ 65.000$,- per bedrijf een stuk hoger. Ook de gemiddelde kosten per getrainde medewerker waren in 2003 veel hoger: $€ 2.100$,- tegenover $€ 1.500$,- in 2004. Dit betekent dat de gestegen tijdsinvestering in scholing gepaard is gegaan met een daling in de investering in directe cursuskosten. Al met al wordt er in 2004 in de gehele Metalektro overigens veel in scholing van het personeel geïnvesteerd. In totaal wordt er bijna $€ 40$ miljoen aan cursussen van het technisch personeel besteed. Gemiddeld genomen is dit $3 \%$ van de loonsom. 
Tabel 5.3

Gemiddelde totale (out of pocket) kosten en gemiddelde loonsompercentage voor cursussen van het technisch personeel, 2004

\begin{tabular}{lrr}
\hline & 2003 & 2004 \\
& & \\
& & \\
Gemiddelde totale kosten per bedrijf (euro) & 65.000 & 41.800 \\
Gemiddelde totale kosten per getrainde werknemer (euro) & * & 1.500 \\
Gemiddeld loonsompercentage (\%) & 3 \\
& \\
* geen gegevens beschikbaar & \\
Bron: ROA/Werkgeverspanel Metalektro 2004 &
\end{tabular}

Driekwart van de directe kosten voor scholing komt voor rekening van het bedrijf (zie figuur 5.2). Het aandeel dat de werknemer betaalt is erg klein: Gemiddeld genomen nemen de werknemers slechts $1 \%$ van de directe cursuskosten voor hun rekening. De rest van de kosten wordt door andere partijen gefinancierd. Het grootst is hierbij de bijdrage van de Stichting A+O: $22 \%$. Daarnaast wordt $2 \%$ van de directe opleidingskosten bekostigd uit ESF-subsidies en $1 \%$ uit andere subsidies.

Figuur 5.2

Percentage van de directe kosten voor cursussen van het technisch personeel dat bekostigd wordt door bedrijf, werknemer of andere partijen, 2004

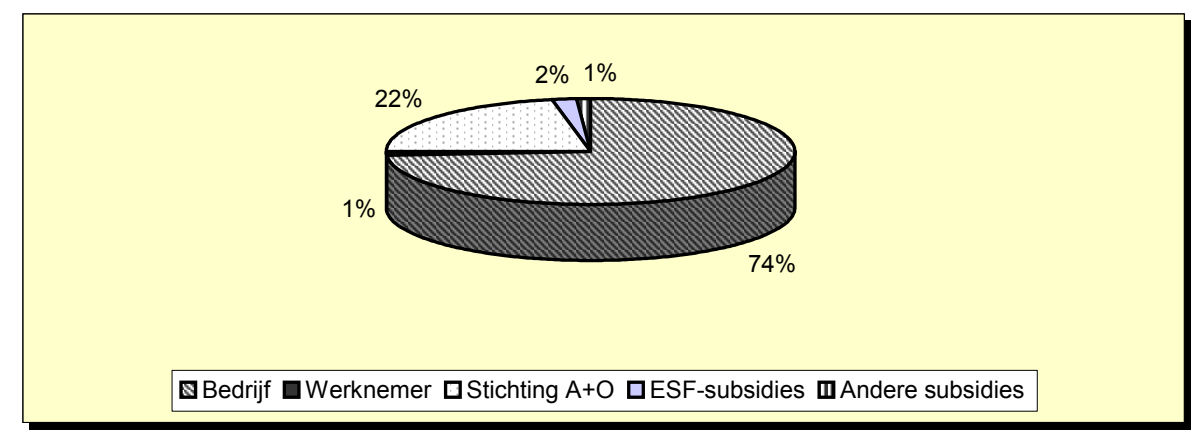

Bron: ROA/Werkgeverspanel Metalektro 2004

\subsection{Het waarom van scholing en het grote belang van informeel leren}

Waarom worden er in de Metalektro eigenlijk zoveel opleidingen gevolgd? Tabel 5.4 laat zien dat er in de meeste bedrijven vooral opleidingen worden gevolgd die gericht zijn op het verbeteren van de vaardigheden van het technisch personeel in hun huidige functie. In $84 \%$ van de bedrijven neemt het technisch personeel aan trainingen en cursussen deel om bestaande vaardigheden in hun huidige functie te verbeteren. In $69 \%$ van de bedrijven worden cursussen gevolgd om nieuwe vaardigheden voor de huidige functie aan te leren. Toch zijn er ook veel bedrijven waarin de scholing van het technisch personeel niet alleen gericht is op de huidige functie. Het vergroten van de inzetbaarheid van werknemers voor andere taken $(60 \%)$ en het aanleren van nieuwe vaardigheden voor de verdere loopbaan $(54 \%)$ 
zijn twee andere veel genoemde doelen van de cursusdeelname van het technisch personeel.

Tabel 5.4

Doelen die een rol spelen bij de cursusdeelname door het technisch personeel, 2004 (\% bedrijven)

Doel

Het verbeteren van bestaande vaardigheden in de functie

Het aanleren van nieuwe vaardigheden voor de huidige functie

Het vergroten van de inzetbaarheid van werknemers voor andere taken

Het aanleren van nieuwe vaardigheden voor de verdere loopbaan

Noot: De verschillende percentages staan los van elkaar en hoeven dus niet op te tellen tot $100 \%$

Bron: ROA/Werkgeverspanel Metalektro 2004

Tijdens gesprekken met deelnemers aan het Werkgeverspanel Metalektro bleek ook dat bedrijven hun personeel niet alleen scholen om ervoor te zorgen dat de competenties voor de huidige functie op het gewenste niveau zijn. Zo gaf een HRMmanager van een bedrijf in de basismetaal aan dat er ook geschoold wordt om mogelijke personeelstekorten in de toekomst voor te zijn. Daarbij gaat het vooral om interne opleidingen: "Omdat we over enkele jaren behoorlijke tekorten verwachten op middelbaar en hoger niveau, proberen we vooral het eigen personeel niveauverhogend te scholen. Daarom hebben we dit jaar het aantal plaatsen in onze bedrijfsschool flink uitgebreid".

In een ander bedrijf wordt er vooral aandacht besteed aan de scholing van het personeel omdat ze in de praktijk zien, dat wanneer dat niet gebeurt, er vaak 'verstarringsproblemen' ontstaan: "We zien het vaak gebeuren dat wanneer werknemers onvoldoende geschoold worden, ze proberen om hun eigen werk helemaal af te gaan bakenen. Wanneer er dan iets verandert, dan komen ze in de problemen, en dat leidt weer tot bijvoorbeeld een burn-out. Juist daarom besteden we zoveel aandacht aan de scholing van ons personeel".

Dat scholing van belang is voor werknemers en werkgevers is dus duidelijk. Toch ondervindt een meerderheid van de Metalektrobedrijven belemmeringen bij de cursusdeelname van hun technisch personeel. De belemmeringen die het meest genoemd worden zijn dat cursussen veel tijd (30\%) en geld (25\%) kosten. Daarnaast vindt één op de vijf bedrijven dat de beschikbare cursussen niet aansluiten op de scholingsbehoefte van het bedrijf. Ook geven bedrijven aan dat cursussen op een ongunstig tijdstip plaatsvinden (16\%), of niet beschikbaar zijn in de regio (12\%). Een betere afstemming van vraag en aanbod van cursussen en trainingen is dus gewenst. Opvallend is echter wel dat in 2004 minder bedrijven met belemmerende factoren voor de cursusdeelname van hun technisch personeel te kampen hadden dan in 2003. In 2003 gaf slechts $23 \%$ van de Metalektrobedrijven aan geen 
belemmeringen te ondervinden; in 2004 was dit gestegen naar $44 \%$ van de bedrijven.

Figuur 5.3

Belemmerende factoren bij de cursusdeelname door het technisch personeel, 2004 (\% bedrijven)

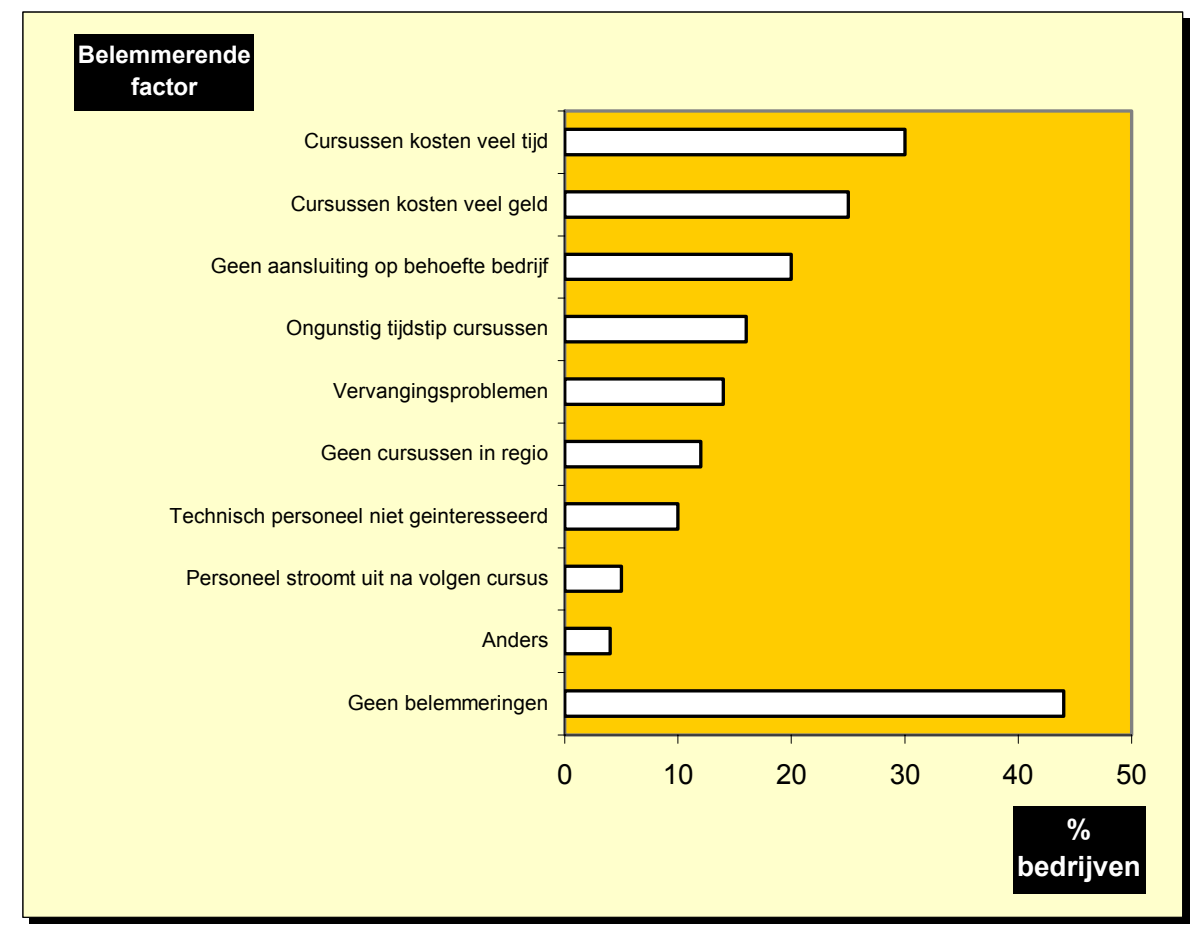

Bron: ROA/Werkgeverspanel Metalektro 2004

Een HRM-manager van een high-tech bedrijf benadrukte dat het bedrijf constant aandacht heeft voor het "bij de tijd houden van de kennis van de medewerkers", maar dat dat lang niet altijd via een formele cursus hoeft te gaan. Naast interne en externe cursussen en trainingen zijn er natuurlijk ook andere manieren waarop het technisch personeel kennis en vaardigheden aan kan leren. Wanneer er sprake is van tekortschietende competenties, dan kunnen die ook aangeleerd worden door informeel leren (het opleiden van personeel op de werkplek) of door 'learning by doing' (het 'automatisch' leren tijdens het werk).

In welke mate zijn deze informele vormen van kennisverwerving in de Metalektro relevant? Tabel 5.5 laat zien dat vaktechnische vaardigheden vooral bijgespijkerd worden door informeel leren: In maar liefst $61 \%$ van de bedrijven wordt een tekort in vaktechnische vaardigheden weggewerkt door het opleiden van personeel op de werkplek, in $55 \%$ van de bedrijven door formele cursussen en in $23 \%$ van de bedrijven door 'learning by doing'. Andere competenties die vooral door informeel leren worden aangeleerd zijn probleemoplossend vermogen, procesgericht werken en omgaan met veranderingen. Zoals we in de hoofdstukken 6 en 7 zullen zien, zijn 
dit de competenties die de komende jaren steeds belangrijker zullen worden in de metalektrosector, terwijl een overgrote meerderheid van de bedrijven tevens aangeeft dat hun technisch personeel op deze punten competentietekorten zullen hebben.

'Learning by doing' (vanzelf leren tijdens het werk) is in veel bedrijven de belangrijkste leerweg voor het bijspijkeren van het goed kunnen werken in teamverband, zelfstandig werken, flexibiliteit, initiatief, het kunnen omgaan met andere culturen en het leervermogen van het personeel. Deze competenties, die allemaal met de werkhouding te maken hebben, worden dus voornamelijk tijdens het werk aangeleerd. Formele cursussen zijn daarentegen met name van belang voor het wegwerken van competentietekorten op het terrein van IT vaardigheden, leidinggeven, communicatieve vaardigheden, taalvaardigheden en veilig gedrag.

Tabel 5.5

Manieren waarop tekortschietende competenties bij het technisch personeel bijgespijkerd worden, 2004 (\% bedrijven)

\begin{tabular}{lrrrr}
\hline Competentie & $\begin{array}{r}\text { Formele } \\
\text { cursus } \\
\%\end{array}$ & $\%$ & $\begin{array}{r}\text { Informeel } \\
\text { 'Learning by Geen tekort } \\
\text { doing' }\end{array}$ & $\%$ \\
\hline Vaktechnische vaardigheden & & & & \\
Werken met computer/IT & 55 & 61 & 23 & 11 \\
Werken in teamverband & 33 & 26 & 24 & 22 \\
Zelfstandig werken & 14 & 25 & 32 & 31 \\
Probleemoplossend vermogen & 5 & 29 & 41 & 27 \\
Procesgericht werken & 8 & 33 & 32 & 27 \\
Leidinggeven & 16 & 29 & 25 & 30 \\
Communicatieve vaardigheden & 44 & 14 & 17 & 27 \\
Taalvaardigheden & 37 & 20 & 19 & 24 \\
Commerciële vaardigheden & 30 & 9 & 19 & 44 \\
Omgaan met veranderingen & 22 & 17 & 15 & 47 \\
Flexibiliteit & 12 & 31 & 33 & 27 \\
Plannen en organiseren & 11 & 27 & 38 & 27 \\
Veilig gedrag & 28 & 24 & 25 & 27 \\
Creativiteit & 34 & 27 & 18 & 27 \\
Initiatief & 4 & 26 & 28 & 44 \\
Omgaan met andere culturen & 8 & 23 & 37 & 34 \\
Leervermogen & 2 & 10 & 37 & 52 \\
& 6 & 23 & 32 & 39 \\
Noot: De verschillende percentages staan los van elkaar en hoeven dus niet op te tellen tot \\
Bron: ROA/Werkgeverspanel Metalektro 2004 & & & & \\
& & & &
\end{tabular}

\subsection{Concurreren met kennis}

Het bovenstaande maakt duidelijk dat zowel formele cursussen en trainingen, als informele scholing en 'learning by doing' een belangrijke plaats in de Metalektrobedrijven innemen. Onder invloed van de concurrentie van bedrijven uit lagelonenlanden zijn de Nederlandse bedrijven genoodzaakt om steeds meer te concurreren op basis van hun 'menselijk kapitaal': de kennis en vaardigheden van hun personeel. De ruime aandacht die er voor competenties en scholing binnen de sector bestaat is 
dan ook niet vreemd. Maar, in welke mate wordt er in de Metalektrobedrijven nu een HRM-beleid gevoerd dat de kennisverwerving van het personeel ondersteunt?

Tabel 5.6 laat zien dat aardig wat bedrijven HRM-instrumenten die gericht zijn op de competentie-ontwikkeling van hun technisch personeel inzetten. Zo heeft $43 \%$ van de bedrijven opleidingsfaciliteiten beschikbaar voor al hun technische werknemers. Nog eens een kwart van de bedrijven biedt deze opleidingsfaciliteiten aan een meerderheid van de technici aan. Een bedrijfsopleidingsplan (BOP) is in bijna driekwart van de bedrijven aanwezig, terwijl 30\% met persoonlijke ontwikkelingsplannen (POP's) werkt. Evenveel bedrijven werken met competentiematrices. Nog maar weinig Metalektrobedrijven proberen met de erkenning van eerder verworven competenties (EVC) de competentie-ontwikkeling van hun technisch personeel te stimuleren. Dat betekent echter niet dat er weinig belangstelling voor EVC bestaat. Enerzijds zal EVC in de meeste bedrijven betrekking hebben op een minderheid van het personeelsbestand. Anderzijds zal in hoofdstuk 6 blijken dat relatief veel bedrijven die nu nog niet bezig zijn met EVC dat wel zien als een belangrijk speerpunt in hun toekomstige HRM-beleid.

Tabel 5.6

Gebruikte HRM-instrumenten om competentie-ontwikkeling bij het technisch personeel te bevorderen, 2004 (\% bedrijven)

\begin{tabular}{|c|c|c|}
\hline HRM-instrument & $\begin{array}{r}\text { Voor alle } \\
\text { technische } \\
\text { werknemers }\end{array}$ & $\begin{array}{r}\text { Voor een } \\
\text { meerderheid } \\
\text { van de } \\
\text { technische } \\
\text { werknemers }\end{array}$ \\
\hline & $\%$ & \\
\hline \multicolumn{3}{|l|}{ Scholing en competenties } \\
\hline Opleidingsfaciliteiten & 43 & 26 \\
\hline Bedrijfsopleidingenplan (BOP) & 55 & 18 \\
\hline Persoonlijk Ontwikkelingsplan (POP) & 24 & 6 \\
\hline Competentiematrix & 18 & 12 \\
\hline Erkenning Verworven Competenties (EVC) & 3 & 5 \\
\hline \multicolumn{3}{|l|}{ Mobiliteit } \\
\hline Loopbaan/carrièreplanning & 8 & 12 \\
\hline Functieroulatie & 9 & 26 \\
\hline Uitwisseling werknemers met andere bedrijfsvestigingen & 5 & 3 \\
\hline Loopbaanadvies/mobiliteitscentrum & 4 & 2 \\
\hline \multicolumn{3}{|l|}{ Communicatie } \\
\hline Functioneringsgesprekken & 73 & 11 \\
\hline Beoordelingsgesprekken & 60 & 12 \\
\hline Scholingsgesprekken & 39 & 18 \\
\hline Geregeld werkoverleg & 56 & 28 \\
\hline
\end{tabular}

Bron: ROA/Werkgeverspanel Metalektro 2004

Tabel 5.6 geeft ook aan dat HRM-instrumenten die primair gericht zijn op de personeelsmobiliteit veel minder vaak worden ingezet om de competentieontwikkeling van het technisch personeel te bevorderen. Het meest wordt nog gebruik gemaakt van functieroulatie (35\%) en loopbaan- of carrièreplanning $(20 \%)$. 64 
HRM-instrumenten die gericht zijn op de communicatie spelen daarentegen wel een belangrijke rol bij het bevorderen van de kennisontwikkeling van het technisch personeel. Meer dan $80 \%$ van de bedrijven zegt door functioneringsgesprekken, beoordelingsgesprekken en geregeld werkoverleg de competentie-ontwikkeling van technici te bevorderen. Ook scholingsgesprekken kunnen hierbij een rol spelen. Deze vinden in iets meer dan de helft van de Metalektrobedrijven plaats. 



\section{De Metalektro in de toekomst}

De Metalektro is een sterk dynamische sector. Veranderingen van allerlei aard volgen elkaar in een snel tempo op. Dat zal in de toekomst ongetwijfeld niet anders zijn. Maar wat gaat er de komende jaren eigenlijk precies veranderen? Om hierop een antwoord te geven, kijken we in dit hoofdstuk allereerst naar de verwachte ontwikkelingen op de arbeidsmarkt en de verwachte instroom van schoolverlaters. Daarna gaan we in op de verwachte veranderingen in de bedrijven zelf en wat de gevolgen daarvan zijn voor de competenties van het personeel. Tenslotte zal worden aangegeven op welke manieren de metalektrobedrijven de komende jaren op de verschillende ontwikkelingen willen gaan inspelen.

\subsection{Meer doen met minder personeel}

Voor de bedrijven in de Metalektro is het van groot belang om enig inzicht te hebben in de wijze waarop de arbeidsmarkt zich de komende jaren zal ontwikkelen. Ondanks dat de werkgelegenheid de komende jaren zal dalen zal er immers toch ook een aanzienlijke vraag naar arbeidskrachten blijven als gevolg van de door de 'vergrijzing' te verwachten toename van de personeelsuitstroom vanwege (pré-) pensionering.

\section{Verwachte veranderingen in de werkgelegenheid}

Hoe zal zich de werkgelegenheid in de metalektrosector zich de komende jaren ontwikkelen? Tabel 6.1 geeft een overzicht van de verwachte jaarlijkse werkgelegenheidsontwikkeling voor de sectoren in de Metalektro in de komende jaren. Voor de sector als geheel is de verwachting dat de werkgelegenheid met bijna $2 \%$ op jaarbasis zal afnemen. Naar verwachting zal de werkgelegenheid het sterkst afnemen in de sector metaalprodukten $(-2,3 \%)$ en in de elektrotechniek $(-2,0 \%)$.

Tabel 6.1

Verwachte uitbreidingsvraag in de Metalektro tot 2008

$\begin{array}{ll}\text { Bedrijfssector } & \begin{array}{l}\text { Gemiddeld } \\ \text { jaarlijks } \%\end{array}\end{array}$

$\begin{array}{lr}\text { Basismetaal } & -1,7 \\ \text { Metaalprodukten } & -2,3 \\ \text { Machine-industrie } & -1,9 \\ \text { Elektrotechniek } & -2,0 \\ \text { Transportmiddelen } & -1,9 \\ \text { Totaal Metalektro } & -1,9\end{array}$

Bron: ROA/CPB/CBS en FME-CWM Conjunctuurmonitor 2003/2004 
In de basismetaal zal er de komende jaren naar verwachting iets minder sprake zijn van een krimpende werkgelegenheid $(-1,7 \%)$. Hoe groot zijn deze krimpcijfers in vergelijking met andere bedrijfssectoren? Volgens het ROA prognoserapport De arbeidsmarkt naar opleiding en beroep tot 2008 krimpt de werkgelegenheid in de Metalektro het sterkst van alle industriële bedrijfssectoren. Terwijl de werkgelegenheid in de Metalektro op jaarbasis met 1,9\% krimpt, neemt de werkgelegenheid in de chemie jaarlijks naar verwachting af met 1,3\%. De krimp in de voedingsindustrie is naar verwachting nog lager (gemiddeld $0,2 \%$ per jaar). Al met al kan dus gesteld worden dat er in de metalektrosector de komende jaren behoorlijk wat werkgelegenheid verloren zal gaan.

\section{Arbeidsmarktprognoses voor specifieke functies}

Wat zijn de gevolgen van de werkgelegenheidskrimp voor de in de Metalektro relevante beroepen? Tabel 6.2 laat duidelijk zien dat er voor de meeste functies sprake is van een krimpende werkgelegenheid. De tabel geeft aan dat bij een krimpende werkgelegenheid het aantal baanopeningen gelijk is aan de vervangingsvraag. Deze verwachting is gebaseerd op de vaststelling dat, op sectorniveau, werkgelegenheidskrimp doorgaans vooral gevolgen heeft voor de uitstroom van personeel en geen negatieve invloed uitoefent op de behoefte aan nieuw personeel op grond van de vervangingsvraag. Daarom is er, ondanks de werkgelegenheidskrimp, voor alle functies de komende jaren nog sprake van een behoorlijk aantal baanopeningen, doordat werknemers die uitstromen uit de Metalektro, bijvoorbeeld

Tabel 6.2

Jaarlijkse uitbreidingsvraag, vervangingsvraag en baanopeningen per beroepsgroep (als gemiddeld jaarlijks percentage van de werkgelegenheid), tot 2008

\begin{tabular}{|c|c|c|c|}
\hline \multirow[t]{2}{*}{ Beroepsgroep } & $\begin{array}{l}\text { Uitbreidings- } \\
\quad \text { vraag }\end{array}$ & $\begin{array}{l}\text { Vervangings- } \\
\text { vraag }\end{array}$ & $\begin{array}{l}\text { Baan- } \\
\text { openingen }\end{array}$ \\
\hline & $\%$ & $\%$ & $\%$ \\
\hline \multicolumn{4}{|l|}{ Technische functies } \\
\hline Monteurs & $-1,3$ & 3,1 & 3,1 \\
\hline Metaalbewerkers & $-1,1$ & 3,1 & 3,1 \\
\hline Bankwerkers en lassers & $-0,7$ & 3,0 & 3,0 \\
\hline Elektromonteurs & $-1,0$ & 2,8 & 2,8 \\
\hline Productiemedewerkers & $-2,1$ & 3,1 & 3,1 \\
\hline $\begin{array}{l}\text { Werktuigbouwkundig ontwerpers en hoofden } \\
\text { technische dienst }\end{array}$ & $-2,4$ & 4,1 & 4,1 \\
\hline Assembleurs & $-0,9$ & 2,7 & 2,7 \\
\hline Laders en lossers & 1,3 & 2,1 & 3,4 \\
\hline Medisch laboranten & 1,3 & 2,3 & 3,6 \\
\hline Installateurs & 0,8 & 2,9 & 3,7 \\
\hline \multicolumn{4}{|l|}{ Administratieve en commerciële functies } \\
\hline Administratief personeel & 1,2 & 2,4 & 3,6 \\
\hline Commercieel medewerkers (HBO niveau) & $-1,3$ & 2,9 & 2,9 \\
\hline Receptionisten en administratieve employés & $-0,5$ & 4,4 & 4,4 \\
\hline Commercieel medewerkers (WO niveau) & $-0,5$ & 2,5 & 2,5 \\
\hline
\end{tabular}

Bron: CBS/CPB/ROA 
doordat ze met (pré-)pensioen gaan, vervangen moeten worden. Bij de technische functies is het percentage baanopeningen het hoogst voor de werktuigbouwkundig ontwerpers en hoofden technische dienst $(4,1 \%)$, medisch laboranten $(3,6 \%)$ en installateurs $(3,7 \%)$. Voor assembleurs en commercieel medewerkers (WO niveau) wordt het laagste percentage baanopeningen verwacht.

\section{Arbeidsmarktprognoses voor specifieke opleidingen}

De verwachte arbeidsmarktontwikkelingen kunnen ook belicht worden vanuit het perspectief van de vraag naar en het aanbod van mensen met een bepaalde opleidingsachtergrond. Tabel 6.3 laat zien dat de uitbreidingsvraag voor de meeste opleidingen die relevant zijn in de Metalektro, negatief is. Vooral voor mensen met een lager opleidingsniveau (bijvoorbeeld mensen met alleen basisonderwijs of met een opleiding VMBO mechanische techniek) wordt er de komende jaren een behoorlijke werkgelegenheidskrimp verwacht. De opleidingen waar wel een groeiende werkgelegenheid voor verwacht wordt, (MBO en HBO elektrotechniek, HAVO/VWO en HBO bedrijfskunde) zijn opleidingen op middelbaar of hoger niveau. Dit illustreert de upgrading van de functie-eisen in de Metalektro: laagopgeleid personeel maakt plaats voor mensen met een opleiding op middelbaar beroepsniveau of hoger.

Tabel 6.3

Jaarlijkse uitbreidingsvraag, en vervangingsvraag per opleidingstype (als gemiddeld jaarlijks percentage van de werkgelegenheid), tot 2008

Opleidingstype
Uitbreidingsvraag Vervangingsvraag

$\%$

$\%$

Technische opleidingen

MBO werktuigbouw en mechanische techniek

VMBO mechanische techniek

MBO elektrotechniek

$\mathrm{HBO}$ werktuigbouwkunde

HBO elektrotechniek

VMBO bouwtechniek

$\begin{array}{rr}-0,5 & 4,0 \\ -4,5 & 3,9 \\ 1,1 & 3,5 \\ -0,2 & 3,4 \\ 1,2 & 3,7 \\ -1,0 & 3,6\end{array}$

Overige opleidingen

Basisonderwijs

$\begin{array}{rr}-5,2 & 4,4 \\ -0,3 & 3,9 \\ 1,8 & 2,8 \\ 0,6 & 3,9 \\ -1,1 & 3,9 \\ 1,3 & 1,9\end{array}$

VMBO theorie

$\mathrm{HAVO} / \mathrm{VWO}$

MBO administratie en logistiek

MBO handel

HBO bedrijfskunde

Bron: CBS/CPB/ROA

Vanwege de vergrijzing van de beroepsbevolking is er voor de meeste van de in tabel 6.3 genoemde opleidingstypen een aanzienlijke vervangingsvraag. De grootste vervangingsbehoefte wordt er verwacht voor werknemers met een opleiding MBO werktuigbouw en mechanische techniek en voor de mensen met alleen basisonderwijs. Aangezien veel bedrijven laagopgeleid personeel dat uitstroomt ver- 
vangen door middelbaar of hoger geschoolde werknemers zal de toekomstige vraag naar mensen met alleen basisonderwijs echter gering zijn (zie de sterk negatieve 'uitbreidingsvraag'). Daarentegen zullen relatief weinig werknemers met een opleiding HBO bedrijfskunde de komende jaren moeten worden vervangen. Vooral de vervangingsvraag zorgt ervoor dat er voor alle in tabel 6.3 genoemde opleidingstypen de komende jaren nog baanopeningen zullen zijn voor nieuwkomers.

\section{Toekomstige instroom van schoolverlaters}

Hoeveel schoolverlaters met een voor de Metalektro relevante opleiding zullen er in de komende jaren beschikbaar komen voor de arbeidsmarkt? Tabel 6.4 geeft een overzicht van het verwachte aantal schoolverlaters op VMBO en MBO niveau, uitgesplitst naar de vier WEB-niveaus:

- $\quad$ niveau 1: assistentenopleidingen;

- $\quad$ niveau 2: basisberoepsopleidingen;

- $\quad$ niveau 3: vakopleidingen;

- $\quad$ niveau 4: middenkader- en specialistenopleidingen.

Om de vergelijking met de afgelopen jaren te kunnen maken wordt het verwachte aantal schoolverlaters voor de periode 2003-2008 vergeleken met het aantal schoolverlaters in de periode 1998-2003.

Tabel 6.4

Instroom op de arbeidsmarkt uit BOL en BBL naar WEB-niveau, 1998-2003 en 2003-2008

\begin{tabular}{lrrr}
\hline Opleidingstype & $\begin{array}{r}\text { WEB- } \\
\text { Niveau }\end{array}$ & 1998-2003 & $2003-2008$ \\
& & aantal & aantal \\
\hline VMBO mechanische techniek & & & \\
VMBO elektrotechniek & 1 & 17.900 & 19.100 \\
MBO werktuigbouw en mechanische techniek & 2 & 12.000 & 13.600 \\
& 3 & 4.600 & 4.200 \\
MBO elektrotechniek & 4 & 2.000 & 2.100 \\
& 2 & 5.400 & 2.500 \\
& 3 & 3.800 & 7.200 \\
& 4 & 9.800 & 6.4000 \\
\hline
\end{tabular}

Bron: CBS/ROA

Uit de tabel blijkt dat de arbeidsmarktinstroom van schoolverlaters op niveau 1 en 2 de komende jaren zal toenemen, terwijl het niveau van de arbeidsmarktinstroom van schoolverlaters met een specialisten- of middenkaderopleiding op niveau 4 zal afnemen. Zo zal de instroom van schoolverlaters met een opleiding VMBO mechanische techniek of elektrotechniek de komende jaren toenemen. Op MBO niveau zal de instroom van schoolverlaters met $\mathrm{MBO}$ werktuigbouw en mechanische techniek op WEB 2 of 4 niveau in totaal met circa 10\% teruglopen. De arbeidsmarktinstroom van schoolverlaters met een MBO-opleiding elektrotechniek op WEB 4 niveau loopt naar verwachting zelfs met maar liefst een derde terug. Tabel 6.3 laat 
zien dat er voor MBO werktuigbouw en mechanische techniek op niveau 3 en MBO elektrotechniek op niveau 2 of 3 daarentegen juist sprake zal zijn van een toename van de arbeidsmarktinstroom van schoolverlaters.

Uit de gesprekken met deelnemers aan het Werkgeverspanel blijkt duidelijk dat er in de toekomst voor bepaalde opleidingsrichtingen tekorten worden verwacht. Zo geeft een bedrijf in de regio Zuid aan dat ze de komende jaren vooral problemen verwacht bij het vinden van freezers en metaalbewerkers op MBO-niveau. Een ander bedrijf geeft aan dat het vinden van goed geschoolde metaalarbeiders de komende jaren een punt van zorg is. Een HRM-functionaris bij een derde bedrijf dat deelnam aan de gesprekken formuleert het nog stelliger: "De beschikbaarheid van technisch personeel zal de komende jaren flink te wensen over laten".

Het aanbod van schoolverlaters van het VMBO en het MBO is, zoals bekend, sterk regionaal gebonden. Het is daarom belangrijk om een beeld te krijgen van de ontwikkelingen van de instroom van schoolverlaters in de verschillende regio's. Tabel 6.5 laat zien dat er tussen de regio's aanzienlijke verschillen zijn in de ontwikkeling van de instroom van schoolverlaters in de komende jaren. Voor de opleidingen op VMBO-niveau krijgt alleen de regio Noord de komende jaren naar verwachting te maken met een afnemende instroom van schoolverlaters. In de overige regio's wordt er een toenemende instroom van schoolverlaters op VMBO verwacht. De grootste toename van de VMBO-instroom wordt verwacht in de regio Oost.

De toekomstige verwachtingen met betrekking tot de ontwikkeling van de instroom van schoolverlaters met een opleiding MBO werktuigbouw en mechanische techniek verschilt sterk per regio en per WEB-niveau. In de regio Zuidwest wordt er de komende jaren op alle niveaus een stijgende instroom verwacht voor schoolverlaters met een opleiding voor MBO werktuigbouw en mechanische techniek. In de regio Rijndelta en de regio Oost wordt er daarentegen op alle niveaus juist een teruglopende instroom van schoolverlaters van deze $\mathrm{MBO}$-opleidingen verwacht. In beide regio's is met name de daling van de instroom van schoolverlaters MBO werktuigbouw en mechanische techniek op niveau 4 aanzienlijk. De instroom van schoolverlaters met deze opleidingsachtergrond zal in deze regio's naar verwachting met bijna een derde afnemen. In de regio's Noord en Zuidoost zal er daarentegen naar verwachting sprake zijn van een groeiende instroom van schoolverlaters met een opleiding MBO werktuigbouw en mechanische techniek op niveau 3.

Bij de ontwikkeling van de instroom van de voor de metalektrosector zo belangrijke opleiding MBO elektrotechniek is er sprake van een duidelijke trend. Het aantal schoolverlaters op niveau 2 zal naar verwachting in alle regio's stijgen. Deze stijging is het sterkst in de regio's Noord, West en Oost. Ook op niveau 3 zal er in alle regio's, met uitzondering van de regio Rijndelta, sprake zijn van een stijgende instroom. De arbeidsmarktinstroom van schoolverlaters met een MBO-opleiding elektrotechniek op niveau 4 zal echter de komende jaren naar verwachting in alle regio's fors dalen. In de regio's West, Zuidwest en Zuidoost zal de instroom van dit type schoolverlaters zelfs met méér dan de helft afnemen, in vergelijking met de afgelopen jaren. 
Tabel 6.4

Regionale toe- en afname van de instroom op de arbeidsmarkt naar WEB-niveau op basis van een vergelijking tussen de jaren 2003-2008 en de periode 1998-2003

\begin{tabular}{|c|c|c|c|c|c|c|c|}
\hline Opleidingstype & $\begin{array}{l}\text { WEB- } \\
\text { Niveau }\end{array}$ & Noord & West & $\begin{array}{l}\text { Rijn- } \\
\text { delta }\end{array}$ & $\begin{array}{l}\text { Zuid- } \\
\text { west }\end{array}$ & $\begin{array}{l}\text { Zuid- } \\
\text { oost }\end{array}$ & Oost \\
\hline & & $\%$ & $\%$ & $\%$ & $\%$ & $\%$ & $\%$ \\
\hline VMBO mechanische techniek & 1 & -13 & 3 & 12 & 5 & 9 & 16 \\
\hline VMBO elektrotechniek & 1 & -15 & 8 & 19 & 9 & 14 & 24 \\
\hline $\begin{array}{l}\text { MBO werktuigbouw en } \\
\text { mechanische techniek }\end{array}$ & $\begin{array}{l}2 \\
3 \\
4\end{array}$ & $\begin{array}{r}-3 \\
19 \\
2\end{array}$ & $\begin{array}{r}-23 \\
0 \\
-18\end{array}$ & $\begin{array}{l}-14 \\
-20 \\
-26\end{array}$ & $\begin{array}{l}6 \\
2 \\
5\end{array}$ & $\begin{array}{r}-13 \\
23 \\
-15\end{array}$ & $\begin{array}{r}-3 \\
-1 \\
-32\end{array}$ \\
\hline MBO elektrotechniek & $\begin{array}{l}2 \\
3 \\
4\end{array}$ & $\begin{array}{r}35 \\
31 \\
-38\end{array}$ & $\begin{array}{r}31 \\
10 \\
-63\end{array}$ & $\begin{array}{r}3 \\
-37 \\
-47\end{array}$ & $\begin{array}{r}23 \\
2 \\
-64\end{array}$ & $\begin{array}{r}20 \\
9 \\
-53\end{array}$ & $\begin{array}{r}27 \\
5 \\
-48\end{array}$ \\
\hline
\end{tabular}

Bron: CBS/ROA

\subsection{Wat verandert er eigenlijk concreet in de bedrijven?}

Wat verandert er eigenlijk de komende jaren in de bedrijven zelf? Figuur 6.1 geeft een overzicht van de veranderingen die de bedrijven het vaakst noemen. Circa driekwart van de bedrijven verwacht dat de klanten de komende jaren steeds veeleisender zullen worden. Ook zal het steeds belangrijker worden dat het personeel over goede gedragsmatige competenties beschikt. Daarnaast zal een groot gedeelte van de bedrijven te maken krijgen met een verder toenemende automatisering $(67 \%)$, meer verantwoordelijkheden op een lager niveau in de organisatie $(64 \%)$ en technische functies die steeds meer all-round worden (64\%). Ook verwacht meer dan de helft van de bedrijven dat het competentiemanagement de komende 5 jaar in belang zal toenemen. Bijna de helft van de bedrijven verwacht de komende jaren de introductie van een nieuwe productietechniek. Een uitspraak van een personeelsfunctionaris in een high-tech bedrijf illustreert hoe snel de productietechniek verandert: "de toepassing van 2 jaar geleden komt nu in ons bedrijf helemaal niet meer voor".

\section{Competentietekorten}

Al deze veranderingen hebben vanzelfsprekend grote gevolgen voor de competenties waarover het personeel moet beschikken. Doordat de productieprocessen en de organisatie van veel metalektrobedrijven in de toekomst zullen veranderen, kunnen er lacunes optreden in de kennis en vaardigheden van het personeel. Maar liefst $86 \%$ van de bedrijven verwacht de komende jaren bepaalde competentietekorten. Maar om welke competentietekorten gaat het dan vooral? 
Figuur 6.1

Verwachte veranderingen in de komende 5 jaar, 2004 (\% bedrijven)

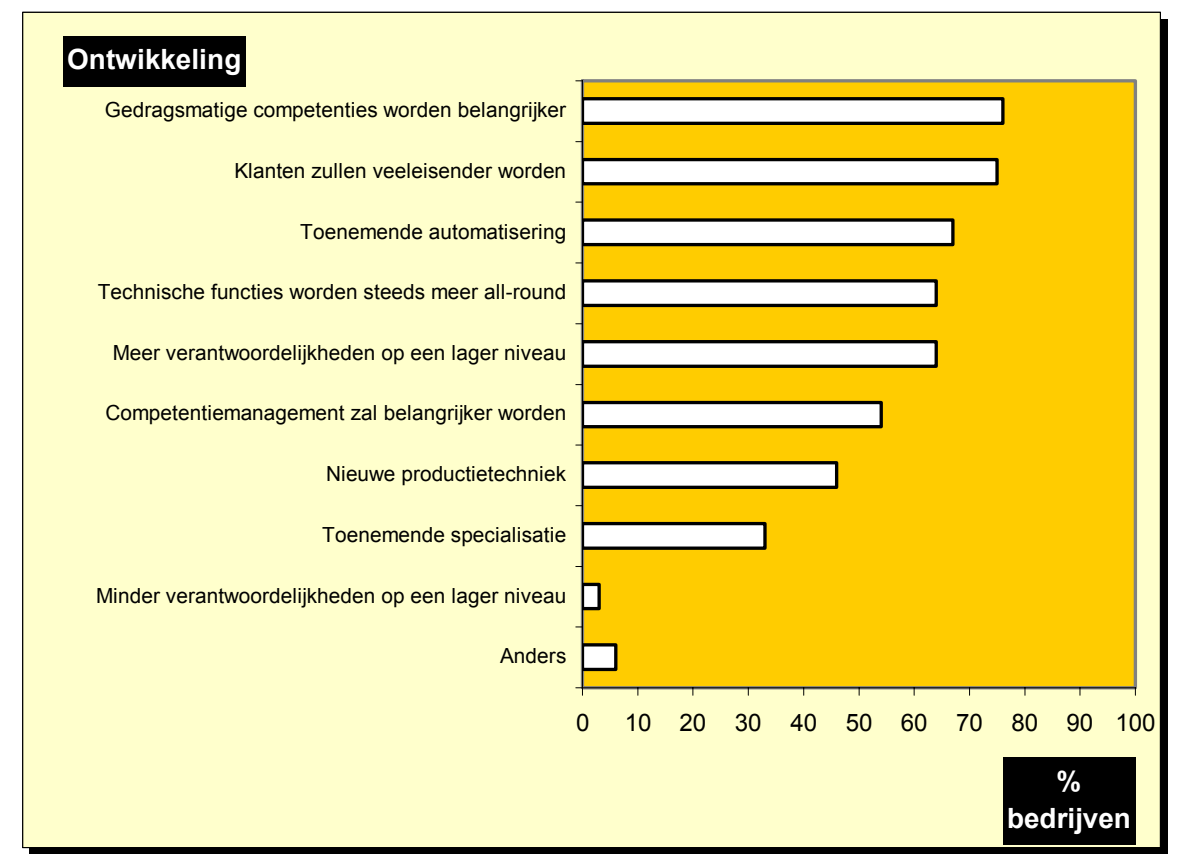

Bron: ROA/Werkgeverspanel Metalektro 2004

Figuur 6.2 laat zien dat bijna een kwart van de metalektrobedrijven grote competentietekorten op het vlak van het probleemoplossend vermogen van het personeel verwacht. Eén op de zes bedrijven verwacht grote competentietekorten met betrekking tot het kunnen omgaan met veranderingen. Ook voor flexibiliteit, het nemen van initiatief en het procesgericht kunnen werken verwachten minstens één op de tien bedrijven de komende jaren grote competentietekorten. Voor het werken in teamverband, veilig gedrag, taalvaardigheden en IT-vaardigheden verwacht daarentegen slechts een klein aantal bedrijven een groot competentietekort. Dat er voor IT-vaardigheden geen grote competentietekorten worden verwacht, terwijl wel veel bedrijven verwachten dat de automatisering de komende jaren zal toenemen (zie figuur 6.1), betekent waarschijnlijk dat de meeste bedrijven reeds beschikken over technisch personeel dat goed kan omgaan met IT en de veranderingen daarin, of dat ze hun personeel op dat vlak al voldoende bijscholen.

Uit de gesprekken met deelnemers aan het Werkgeverspanel Metalektro kwam naar voren dat de urgentie van de verwachte competentietekorten op het terrein van het probleemoplossend vermogen, het omgaan met veranderingen en de flexibiliteit van het personeel zeer groot is. Volgens de HRM-manager van een constructiebedrijf gaat het vooral om het kunnen coördineren en het 'verbeter-minded' zijn van het personeel: "Het in huis hebben van dat soort personeel is essentieel voor het bedrijf om op de lange termijn te kunnen overleven. De markt eist namelijk voortdurend aanpassingen en daarvoor zijn mensen nodig die de benodigde procesinnovatie op verschillende terreinen goed kunnen uitvoeren". Een high-tech bedrijf ziet vooral 
problemen in de toekomst voor wat betreft de flexibiliteit en het kunnen omgaan met veranderingen: "Wanneer we deze tekorten niet op tijd aanpakken dan kan dat op termijn dodelijk zijn voor het bedrijf. Het is overigens niet alleen een probleem voor ons bedrijf. Deze problematiek speelt metaalbreed. De werkgevers hebben het personeel veel te lang verwend en zullen daar in de toekomst 'vreselijk' voor gestraft worden".

Figuur 6.2

Grote competentietekorten bij het technisch personeel in de komende 5 jaar, 2004 (\% bedrijven)

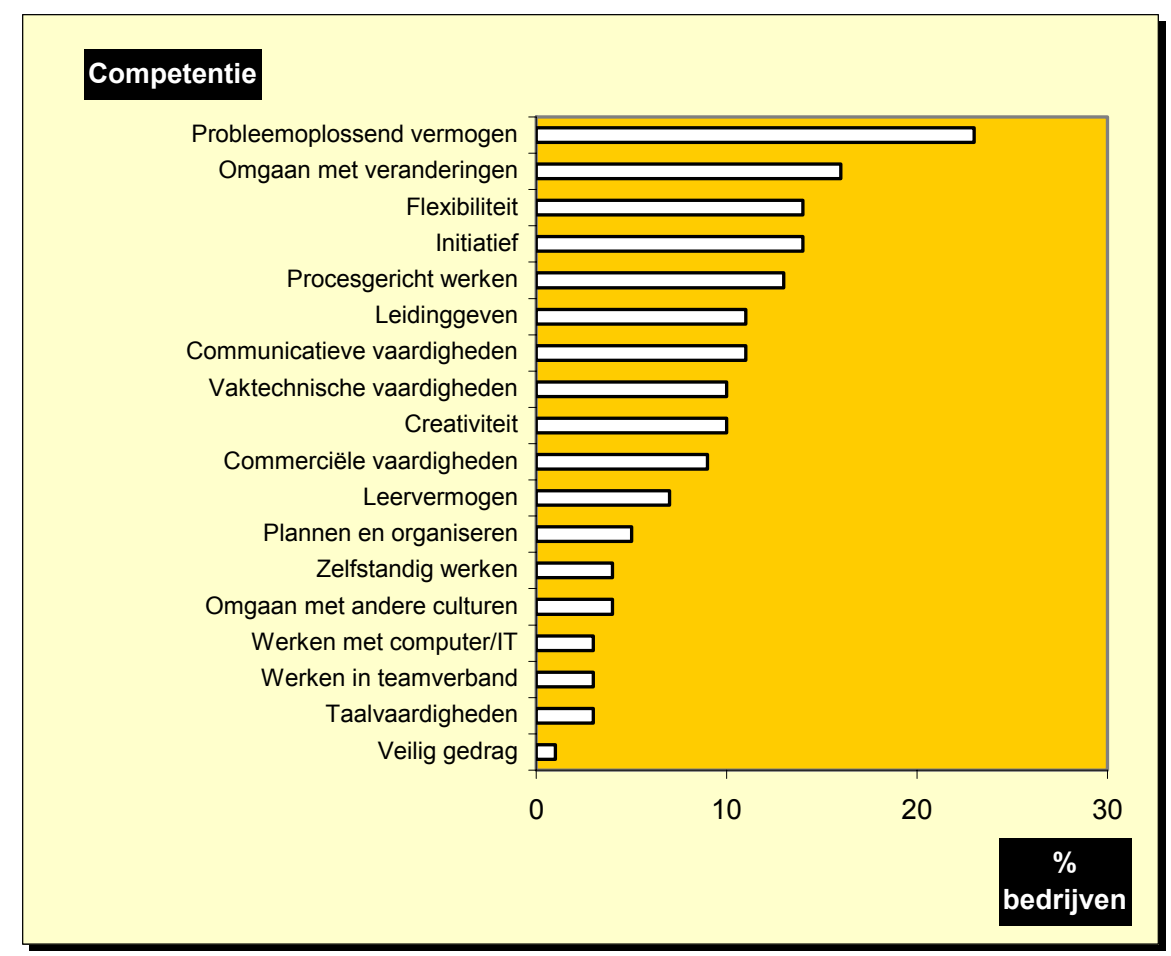

Bron: ROA/Werkgeverspanel Metalektro 2004

Enkele bedrijven zien ook nog andere competentietekorten in de toekomst. Het gaat dan bijvoorbeeld om het vinden van nieuwe kansen, mogelijkheden of markten ('ondernemerschap in het werk'), zelfredzaamheid en initiatief. Het gebrek aan deze competenties levert nu soms al problemen op. Volgens een personeelsmanager kon er enige tijd geleden in haar bedrijf niet tijdelijk worden overgegaan naar een 5ploegendienst, toen daar wegens grote drukte behoefte aan was: "Er waren eenvoudigweg niet genoeg capabele mensen die dat in goede banen konden leiden. Daar hebben we wel van geleerd. Onlangs hebben we op de werkvloer een nieuwe functie gecreëerd (assistent-voorman) en zijn we weer stevig aan het opleiden". Opvallend is dat die opleidingen zich vooral richten op het aanleren van gedragsmatige competenties. Onder meer het omgaan met weerstand, effectieve communicatie en het binden en boeien van personeel komen uitgebreid aan de orde. Het belang van gedragsmatige competenties speelt ook bij andere bedrijven. Een bedrijf 
uit de metaalbewerking stelt dat "het willen en kunnen oplossen van problemen sterk gerelateerd is aan de flexibiliteit van de mensen, die natuurlijk verbonden is met persoonlijkheidsaspecten". "Niet alleen de kennis, maar vooral de bereidheid om zich flexibel op te stellen is een cruciale factor", aldus de personeelsmanager.

\subsection{Kenniseconomie in de Metalektro}

De verwachte competentietekorten bij het personeel en de ingrijpende veranderingen die door veel metalektrobedrijven voor de komende jaren verwacht worden noodzaken de bedrijven ertoe om daar met hun beleid op in te spelen. De aandacht voor de kennis en vaardigheden van het personeel vanuit het besef dat juist het personeel de belangrijkste productiefactor is om als bedrijf succesvol te blijven, wordt aangeduid met het begrip kenniseconomie. Het is duidelijk dat de Nederlandse metalektro-industrie hier deel van uitmaakt.

In de kenniseconomie spelen bedrijven door hun HRM-beleid in op de veranderende behoefte aan kennis en vaardigheden. Maar om welke speerpunten in het HRMbeleid gaat het eigenlijk? Tabel 6.5 geeft aan dat het bij verreweg de meeste metalektrobedrijven ( $87 \%$ ) gaat om het bevorderen van de brede inzetbaarheid van het personeel. Ook het bevorderen van coachend leiderschip is een opmerkelijk belangrijk aandachtspunt. Meer dan de helft van de metalektrobedrijven ziet dit als een speerpunt voor hun HRM-beleid. Dat betekent dat veel bedrijven hun beleid richten op het stimuleren van informeel leren tussen leidinggevenden en het technisch personeel. Het is opvallend dat meer bedrijven aangeven hun beleid te willen richten op het verbreden van de inzetbaarheid van hun personeel of het informeel leren dan het aantal bedrijven dat zegt met het beleid de cursusdeelname van het personeel wil vergroten (43\%). Dit onderstreept duidelijk het grote belang dat de bedrijven hechten aan het informeel leren van hun personeel. Ten slotte geeft $62 \%$ van de bedrijven aan dat ze door middel van hun HRM-beleid het verzuim willen verminderen.

Circa één derde van de bedrijven richt het beleid op het intensiveren van de samenwerking met andere bedrijven. Zoals in hoofdstuk 4 werd aangegeven kan het daarbij bijvoorbeeld gaan om het collegiaal in- en uitlenen van personeel. Circa een kwart van de bedrijven ziet ook het intensiveren van de samenwerking met onderwijsinstellingen en de erkenning van de verworven competenties (EVC) van het personeel als een speerpunt voor hun toekomstig HRM-beleid. Dit wijst erop dat EVC de komende jaren in een soort 'take-off' fase lijkt terecht te komen, waarin het breder verspreid raakt in de sector. $13 \%$ van de bedrijven besteedt in het beleid expliciet aandacht aan het voorkomen van vroegtijdige uitstroom. Hoewel in voorgaande hoofdstukken bleek dat de vergrijzingsproblematiek in veel bedrijven een belangrijke rol speelt, zijn de problemen bij de meeste bedrijven naar verwachting niet zo groot dat men dit als een speerpunt voor toekomstig HRM-beleid ziet. 
Tabel 6.5

Speerpunten waarop bedrijven in de komende 5 jaar beleid gaan voeren, 2004 (\% bedrijven)

Speerpunten

Het bevorderen van de brede inzetbaarheid van het personeel 87

Het verminderen van verzuim $\quad 62$

Het bevorderen van coachend leiderschap $\quad 54$

Het stimuleren van cursusdeelname

Het intensiveren van de samenwerking met andere bedrijven 36

Het intensiveren van de samenwerking met onderwijsinstellingen 26

EVC $\quad 25$

Het voorkomen van voortijdige uitstroom 13

Anders

Noot: De verschillende percentages staan los van elkaar en hoeven dus niet op te tellen tot $100 \%$.

Bron: $\quad$ ROA/Werkgeverspanel Metalektro 2004

Problemen met tekortschietende competenties vóór zijn

Het besef dat toekomstige competentietekorten van het personeel tot grote problemen kunnen leiden is inmiddels goed tot de bedrijven in de Metalektro doorgedrongen. Vrijwel alle bedrijven in de sector nemen nu al maatregelen om dergelijke tekorten voor te zijn. Ook hier staat weer het bevorderen van de brede inzetbaarheid van het personeel centraal. Tabel 6.6 geeft aan dat $84 \%$ van de bedrijven aangeeft daar nu al mee bezig te zijn om toekomstige problemen te voorkomen. Daarnaast speelt ook het ontwikkelen van de medewerkers, zowel on-the-job als door cursussen een belangrijke rol. Bijna driekwart van de bedrijven geeft aan dat ze op deze manier toekomstige problemen bij competentietekorten te lijf gaan. De kennisontwikkeling hoeft echter niet altijd plaats te vinden door middel van formele trainingen of cursussen. Meer dan de helft van de bedrijven wil maatregelen nemen om de informele kennisuitwisseling tussen werknemers te stimuleren.

$45 \%$ van de bedrijven probeert toekomstige competentietekorten te voorkomen door nu al nieuw, goed gekwalificeerd, personeel aan te trekken. In combinatie met de (toekomstige) uitstroom van personeel door (pré-)pensionering betekent dit dat deze bedrijven in feite problemen toekomstige competentietekorten te voorkomen door hun personeelsbestand vroegtijdig te verversen.

Circa éénderde van de bedrijven probeert competentieproblemen voor te zijn door het personeel competentiegericht te gaan beoordelen. Op deze manier probeert men de competentietekorten in kaart te brengen zodat er pro-actief op kan worden ingespeeld. $15 \%$ van de bedrijven denkt door het erkennen van de verworven competenties beter inzicht te krijgen in de competenties van het personeel. Ook dit stelt het bedrijf beter in staat om actie te ondernemen indien blijkt dat er lacunes in de kennis en vaardigheden van het personeel bestaan. Slechts $6 \%$ van de bedrijven probeert vroegtijdige uitstroom te voorkomen, zodat de bij het personeel aanwezige kennis minder snel verloren gaat. 
Tabel 6.6

Huidige maatregelen om mogelijke problemen met tekortschietende competenties bij het technisch personeel in de komende 5 jaar te voorkomen, 2004 (\% bedrijven)

Maatregelen

Vergroten van de brede inzetbaarheid van het personeel $\quad 84$

Personeel op de werkplek opleiden

Personeel cursussen aanbieden $\quad 74$

Stimuleren kennisuitwisseling tussen werknemers $\quad 53$

Aannemen van nieuw, gekwalificeerd personeel 45

$\begin{array}{ll}\text { Het bevorderen van competentiegerichte beoordelingen } & 37\end{array}$

EVC trajecten $\quad 15$

Voorkomen van vroegtijdige uitstroom

Geen speciale maatregelen 3

Noot: De verschillende percentages staan los van elkaar en hoeven dus niet op te tellen tot $100 \%$

Bron: ROA/Werkgeverspanel Metalektro 2004

Natuurlijk kunnen bedrijven altijd meer doen dan het beleid dat momenteel gevoerd wordt om problemen met competentietekorten in de toekomst te voorkomen. Tabel 6.7 geeft een overzicht van de wensen die de bedrijven op dit punt hebben. Bijna de helft van de bedrijven geeft aan in de toekomst meer aandacht te willen besteden aan het opleiden van het personeel op de werkplek. Ook het verder verbreden van de inzetbaarheid is voor veel bedrijven (47\%) een punt dat in de toekomst meer aandacht moet krijgen. $44 \%$ van de bedrijven wil in de toekomst meer aandacht gaan besteden aan het aanbieden van cursussen. Een iets lager percentage van de bedrijven $(38 \%)$ denkt dat de kennisuitwisseling tussen werknemers nog verder gestimuleerd kan worden. $31 \%$ van de bedrijven vindt dat er in de toekomst meer nieuw gekwalificeerd personeel zou moeten worden aangenomen, of dat er meer gebruik gemaakt moet worden van competentiegerichte beoordelingen om problemen met tekortschietende competenties te voorkomen. Ten slotte zegt $16 \%$ van de

Tabel 6.7

Gewenste maatregelen om mogelijke problemen met tekortschietende competenties bij het technisch personeel in de komende 5 jaar te vermijden, 2004 (\% bedrijven)

Personeel op de werkplek opleiden

Vergroten van de brede inzetbaarheid van het personeel $\quad 47$

Personeel cursussen aanbieden $\quad 44$

Stimuleren kennisuitwisseling tussen werknemers 38

Aannemen van nieuw, gekwalificeerd personeel $\quad 31$

Het bevorderen van competentiegerichte beoordelingen $\quad 31$

EVC trajecten $\quad 16$

Voorkomen van vroegtijdige uitstroom $\quad 10$

Geen speciale maatregelen 16

Noot: De verschillende percentages staan los van elkaar en hoeven dus niet op te tellen tot $100 \%$.

Bron: $\quad$ ROA/Werkgeverspanel Metalektro 2004 
bedrijven in de toekomst meer aandacht te willen besteden aan EVC trajecten en geeft $10 \%$ van de bedrijven aan dat ze in de toekomst verdere maatregelen willen nemen om vroegtijdige uitstroom te voorkomen. $16 \%$ van de bedrijven heeft geen speciale wensen met betrekking tot maatregelen die nog genomen kunnen worden om problemen met competentietekorten in de toekomst te voorkomen. 


\section{De werknemer van de toekomst}

De upgrading van functie-eisen speelt in veel bedrijven in de Metalektro een belangrijke rol. Met upgrading wordt bedoeld dat het werk steeds meer kennis en vaardigheden vereist. Maar, om welke competenties gaat het precies? Welke competenties zijn in de toekomst cruciaal om concurrerend te kunnen blijven werken? Het blijkt dat het hierbij niet alleen om vaktechnische kennis gaat, maar ook om zaken als flexibiliteit en multi-inzetbaarheid. Daarom wordt er in dit hoofdstuk ook gekeken naar de inzetbaarheid van het personeel en in hoeverre daar gebruik van wordt gemaakt. Door te kijken naar vereiste competenties en de vereiste flexibiliteit van het technisch personeel ontstaat er een beeld van de kenmerken van de gewenste werknemers van de toekomst.

\subsection{Upgrading}

Evenals in veel andere sectoren van de Nederlandse economie, is er ook in de metalektrosector sprake van een upgrading van de voor een goede functievervulling vereiste competenties. Hierdoor vereist het werk steeds hoger opgeleide werknemers. In tabel 7.1 wordt een overzicht gegeven van de mate waarin het opleidingsniveau in de Metalektro de afgelopen jaren is veranderd. De tabel laat duidelijk zien dat het aandeel van werknemers zonder een startkwalificatie op minimaal MBOniveau sterk gedaald is van $44 \%$ in $1993 / 1994$ tot $35 \%$ in $2001 / 2002$. Dat komt vooral doordat in 8 jaar tijd het aandeel van in de Metalektro werkzame personen met alleen basisonderwijs met maar liefst 5\%-punt daalde. Maar ook op VMBO-niveau was er sprake van een daling met 4\%-punt. Voor de middelbare en hogere opleidingsniveaus zien we daarentegen juist een stijgende trend. In 2001/2002 was het werkgelegenheidsaandeel van de middelbaar opgeleide werknemers $5 \%$-punt hoger dan acht jaar daarvoor. In die periode steeg ook het aandeel van werknemers met een $\mathrm{HBO}$ - of een academische opleiding, respectievelijk met 3 en 1\%-punt.

Tabel 7.1

Aandeel van werknemers naar opleidingsniveau in de Metalektro, 2001-2002 in vergelijking met 1993-1994

\begin{tabular}{lrrr}
\hline Opleidingsniveau & 1993-'94 & 2001-'02 & Verandering \\
& $\%$ & $\%$ & $\%$-punt \\
& & & \\
Basisonderwijs & & 9 & -5 \\
VMBO & 14 & 26 & -4 \\
MBO/HAVO/VWO & 30 & 46 & 5 \\
HBO & 41 & 14 & 3 \\
WO & 11 & 5 & 1
\end{tabular}

Noot: Aangezien het CBS een wat bredere definitie hanteert van de Metalektro, kunnen de cijfers enigszins vertekend zijn.

Bron: CBS/ROA 
Ook in de toekomst zal er voor veel functies in de Metalektro sprake zijn van verder stijgende opleidingseisen. Daardoor zal de vraag naar laagopgeleide werknemers afnemen, terwijl de vraag naar middelbaar en hoogopgeleide werknemers juist toeneemt. Uit gesprekken met de deelnemende bedrijven aan het Werkgeverspanel blijkt de noodzaak van het verhogen van het opleidingsniveau van de medewerkers. Een bedrijf dat grote installaties bouwt stelt dat de situatie ten opzichte van vroeger duidelijk is veranderd: "vroeger kon een werknemer met een V(M)BO opleiding nog prima doorstromen van de productie naar de werkvoorbereiding. $\mathrm{Nu}$ is dat vrijwel ondenkbaar doordat de complexiteit van het werk enorm is toegenomen". Een ander bedrijf stelt dat ze op dit moment nog wel laagopgeleide werknemers in dienst hebben maar dat het hier meestal om oudere werknemers gaat, die binnen afzienbare tijd met pensioen zullen gaan: "Wanneer die mensen vervangen worden komt er vrijwel altijd iemand met minimaal een opleiding op MBO-niveau voor in de plaats". Een klein bedrijf in de automotive-sector wijst erop dat de upgrading van de kwalificatie-eisen ook gerelateerd is aan de vraag naar kwaliteit: "Vroeger stonden er bij ons aan de lopende band vooral laagopgeleiden, maar door de toenemende vraag naar kwaliteit, die onder meer voortvloeit uit de aandacht voor ISO-normen, werken we nu vooral met middelbaar opgeleide mensen". Toch blijken niet alle bedrijven in even grote mate geconfronteerd te worden met de noodzaak om hun laagopgeleid personeel tot MBO-niveau op te scholen. Een personeelsmanager van een bedrijf in de metaalproductenbranche: "Ook in de toekomst blijt er een kleine behoefte aan laagopgeleid personeel. Die mensen zijn in de praktijk ook moeilijk tot MBO-niveau om te scholen. Maar dat betekent niet dat deze mensen helemaal niet geschoold worden. Vooral op het vlak van een goede beheersing van de Nederlandse taal en kwaliteitsbewustzijn worden ook deze werknemers geschoold, omdat het competenties zijn die voor iedereen in het bedrijf van groot belang zijn".

\subsection{Toekomstgericht denken over competenties}

De stijging van het vereiste opleidingsniveau in veel banen in de Metalektro is dus het resultaat van veranderingen in de vereiste competenties. Innovatie, zowel op het vlak van producten en diensten als productieprocessen (zie hoofdstuk 1), die in de metalektrobedrijven plaatsvindt, zal ook in de toekomst belangrijke gevolgen hebben voor de in het werk benodigde competenties. Maar om welke competenties gaat het dan precies? Om op die vraag een antwoord te kunnen geven is aan de bedrijven gevraagd in hoeverre ze vinden dat bepaalde competenties in de komende 5 jaar belangrijker worden. Figuur $7.1 \mathrm{geeft}$ daarvan een overzicht.

Het blijkt dat de bedrijven in de toekomst een grote behoefte hebben aan flexibel personeel. Bijna $80 \%$ van de bedrijven geeft aan dat flexibiliteit in de toekomst een belangrijke competentie wordt. Ook vinden veel bedrijven dat het beschikken over probleemoplossend vermogen en het kunnen omgaan met veranderingen in de toekomst belangrijker zullen worden. Meer dan de helft van de bedrijven vindt bovendien dat het nemen van initiatief, het kunnen plannen en organiseren, communicatieve vaardigheden en het procesgericht kunnen werken belangrijker worden. Ten slotte verwacht een minderheid van de bedrijven dat veilig gedrag, leidinggeven, 
commerciële vaardigheden, taalvaardigheden en het kunnen omgaan met andere culturen de komende 5 jaar in belang zullen toenemen.

Uit de gesprekken met HRM'ers in de Metalektrobedrijven komt ook duidelijk naar voren dat de bedrijven eensgezind zijn over het toenemende belang van gedragsmatige competenties. Enkele bedrijven beschrijven dat ook in termen als het leervermogen en het vermogen om "nieuwe dingen te doen". In een bedrijf waarin de organisatie van het werk sterk verandert doordat bepaalde delen van de productie worden uitbesteed, geeft men aan dat het kunnen coördineren en het toezicht kunnen houden steeds belangrijker worden. Direct daaraan gerelateerd is het toenemende belang van het goed kunnen communiceren met collega's of leidinggevenden. Een high-tech bedrijf legt de nadruk op een verschuiving van de inzet van werknemers die gespecialiseerd zijn op een bepaald terrein naar werknemers die over competenties beschikken die de grenzen van verschillende techniekdisciplines overschrijden. Een ander bedrijf benadrukt dat er steeds minder mensen nodig zijn die enkel één machine bedienen. Daarom wordt er van de werknemers verwacht dat ze op verschillende machines kunnen worden ingezet: "Dat vereist een behoorlijke flexibiliteit en een bredere kennis van dit personeel".

Figuur 7.1

Toename van het belang van verschillende competenties voor het technisch personeel in de komende 5 jaar, 2004 (\% bedrijven)

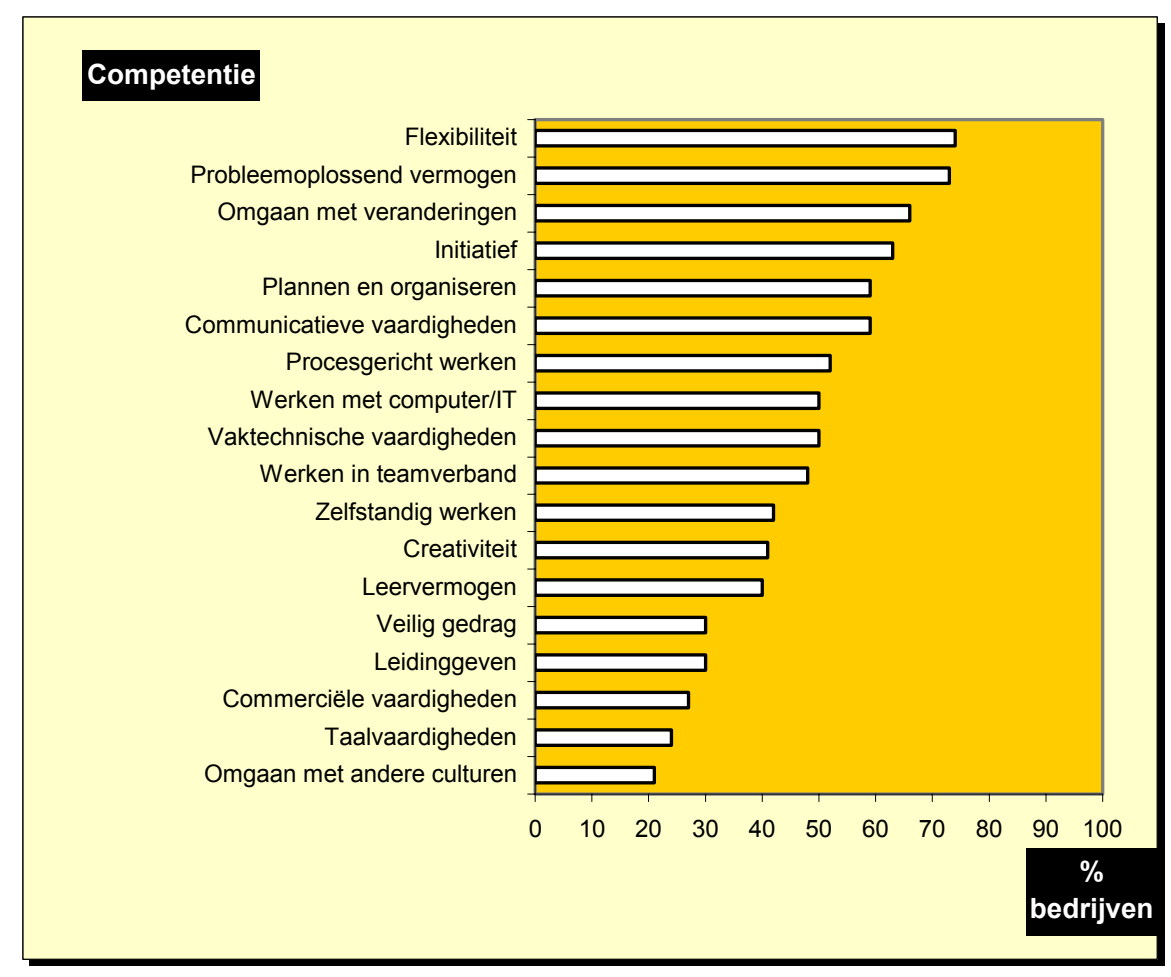

Bron: ROA/Werkgeverspanel Metalektro 2004 
Wat betekenen de verwachte verschuivingen in de vereiste competenties voor het scholingsbeleid van de metalektrobedrijven? Figuur 7.2 geeft een overzicht van het percentage bedrijven dat de komende jaren in hun scholingsbeleid meer aandacht wil besteden aan het verbeteren van bepaalde competenties van hun personeel. Het is opmerkelijk dat, ondanks het beeld in figuur 7.1, de meerderheid van de metalektrobedrijven toch vindt dat er de komende tijd meer aandacht besteed moet worden aan cursussen en training die gericht zijn op het verbeteren van vaktechnische vaardigheden. Een grote groep bedrijven vindt dat er in de toekomst meer aandacht moet worden besteed aan het probleemoplossend vermogen en de communicatieve vaardigheden van het personeel. Daarentegen vindt slechts een minderheid van de bedrijven dat er in de komende jaren meer aandacht moet worden besteed aan taalvaardigheden, leervermogen en het kunnen omgaan met andere culturen.

\section{Figuur 7.2}

Competenties waaraan in de toekomst bij cursussen en trainingen voor het technisch personeel meer aandacht besteed zou moeten worden, 2004 (\% bedrijven)

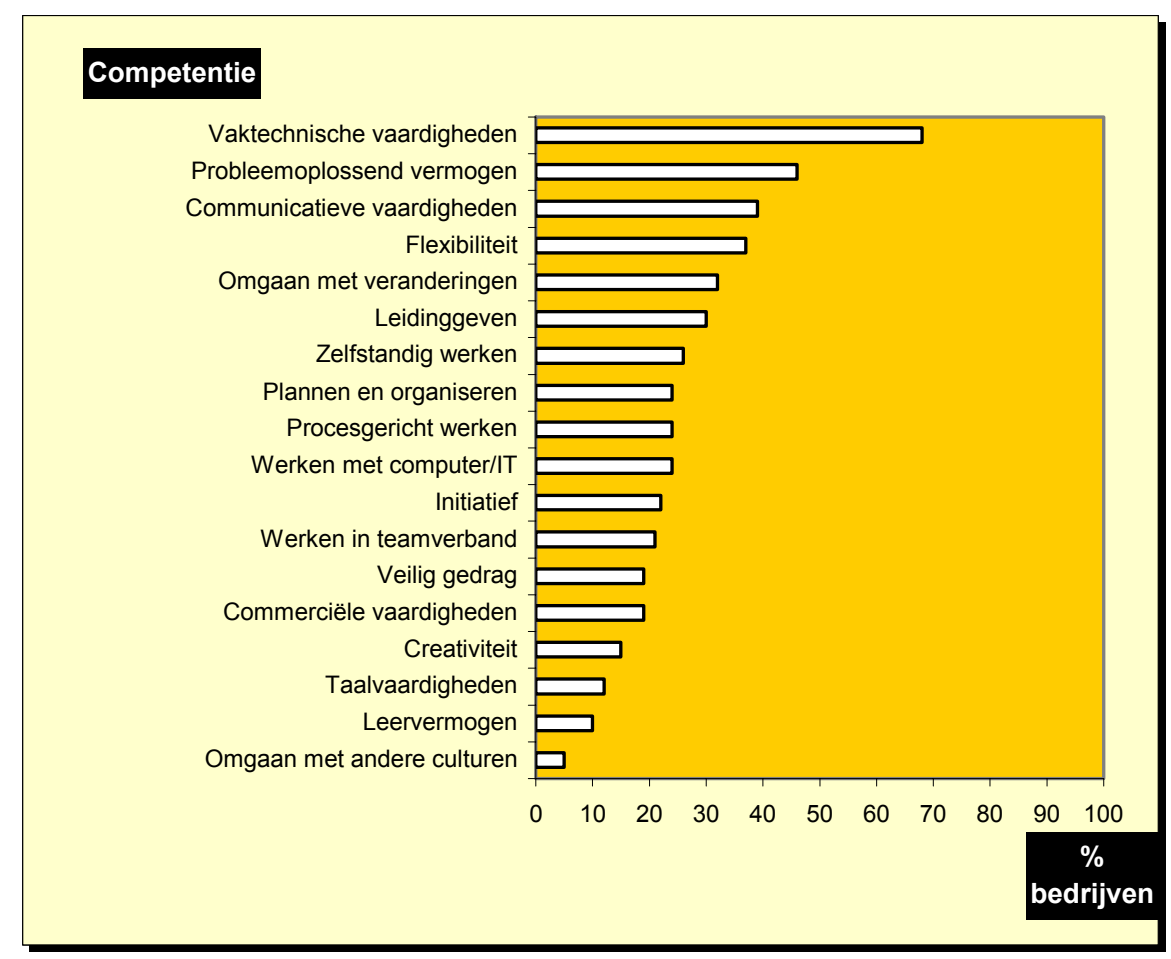

Bron: ROA/Werkgeverspanel Metalektro 2004

Dat maar liefst $70 \%$ van de bedrijven aangeeft dat ze vinden dat er de komende jaren bij cursussen en trainingen van het personeel meer aandacht besteed moet worden aan vaktechnische vaardigheden, onderstreept de voortschrijdende upgrading van de vereiste vaktechnische kennis en vaardigheden. Toch blijkt dat vakkennis op zich niet voldoende is. Van de bedrijven waarmee gesprekken gevoerd werden geeft het merendeel aan dat het vooral gaat om de combinatie van het up-to- 
date houden of verbeteren van vakkennis met het beschikken over voldoende probleemoplossend vermogen. Bovendien vereist dit dat men bereid moet zijn om zich nieuwe kennis eigen te maken en de competenties waarover men beschikt flexibel in te zetten. Een bedrijf beschreef het kort en krachtig: "we hebben in de toekomst vooral mensen nodig die eerst denken, en dan pas doen".

\subsection{Wie is er inzetbaar?}

Goed en breed inzetbaar personeel is voor de bedrijven in de Metalektro van groot belang. Maar wat wordt er eigenlijk precies met inzetbaarheid bedoeld? Om daarop een antwoord te kunnen geven is aan de bedrijven gevraagd wat ze onder inzetbaarheid verstaan.

Tabel 7.2 laat zien dat bijna drie op de tien bedrijven vindt dat inzetbaarheid van het personeel inhoudt dat de mensen inzetbaar zijn in andere functies dan de eigen functie of taken kunnen uitvoeren die niet tot de eigen functie behoren. Eén op de vier bedrijven ziet inzetbaarheid als het vermogen om ingezet te worden op een andere werkplek of afdeling. $23 \%$ van de bedrijven ziet inzetbaarheid als het beschikken over verschillende soorten kennis. $11 \%$ van de bedrijven ziet inzetbaarheid vooral als het vermogen om zowel voor andere taken of functies als ook op andere afdelingen of werkplekken ingezet te worden. Slechts een beperkt aantal bedrijven ziet inzetbaarheid als de bereidheid tot flexibel gedrag. Uit deze antwoorden blijkt duidelijk dat inzetbaarheid niet louter een kwestie is van bereidheid, maar ook betekent dat werknemers over de competenties moeten beschikken om uiteenlopende werkzaamheden te verrichten.

Tabel 7.2

Wat verstaan metalektrobedrijven onder de inzetbaarheid van hun personeel?, 2004 (\% bedrijven)

Definitie

Inzetbaar in functies of taken anders dan de eigen functie 30

Inzetbaar op andere afdeling of werkplek $\quad 25$

Beschikken over verschillende soorten kennis 23

Inzetbaar in andere taken/functies/afdelingen/werkplekken 11

Bereidheid tot flexibel gedrag $\quad 6$

Flexibiliteit

Bron: ROA/Werkgeverspanel Metalektro 2004

\section{Huidige inzetbaarheid van het personeel}

Hoe staat het met de inzetbaarheid van het personeel? Tabel 7.3 geeft een overzicht van de mate waarin bedrijven vinden dat hun personeel inzetbaar is. Allereerst blijkt dat weinig bedrijven vinden dat hun personeel helemaal niet breed inzetbaar is. Voor het uitvoerend en leidinggevend personeel vindt slechts $1 \%$ van de bedrijven dat het personeel niet breed inzetbaar is. Opvallend is dat voor wat betreft het uitvoerend technisch personeel dit percentage gedaald is: in 2003 gaf nog $4 \%$ van de bedrijven aan dat het uitvoerend technisch personeel niet breed inzetbaar was. 
Circa driekwart van de bedrijven geeft aan dat het uitvoerend en leidinggevend technische personeel in grote mate of volledig inzetbaar is. Ter vergelijking: in 2003 gaf slechts de helft van de bedrijven aan dat dit het geval was. Technisch opgeleide verkopers zijn daarentegen duidelijk wat minder inzetbaar: 40\% van de bedrijven vindt dat ze slechts beperkt inzetbaar zijn, terwijl 17\% van de bedrijven zelfs aangeeft dat ze vinden dat technisch opgeleide verkopers helemaal niet breed inzetbaar zijn. Ook het personeel dat betrokken is bij ontwikkeling en engineering wordt door de meerderheid van de bedrijven als slechts beperkt of niet breed inzetbaar gezien. Bij het (hoger) management is daarentegen de inzetbaarheid volgens de bedrijven hoger. Een kwart van de bedrijven vindt het managementpersoneel zelfs volledig inzetbaar, terwijl drie op de tien bedrijven aangeeft dat ze vinden dat het (hoger) management in grote mate inzetbaar is. Voor wat betreft het ondersteunend, administratief of niet-technisch verkooppersoneel is de inzetbaarheid relatief laag. Meer dan de helft van de bedrijven vindt dat dit personeel slechts beperkt inzetbaar is, terwijl $9 \%$ van de bedrijven aangeeft dat het ondersteunend personeel helemaal niet breed inzetbaar is.

Tabel 7.3

Inzetbaarheid van het personeel naar functiecategorie, 2004 (\% bedrijven)

\begin{tabular}{|c|c|c|c|c|}
\hline Functiecategorie & $\begin{array}{r}\text { Volledig } \\
\%\end{array}$ & $\begin{array}{r}\text { In grote } \\
\text { mate } \\
\%\end{array}$ & $\begin{array}{r}\text { Beperkt } \\
\%\end{array}$ & $\begin{array}{r}\text { Niet } \\
\%\end{array}$ \\
\hline Uitvoerende technische functies & 10 & 63 & 26 & 1 \\
\hline Leidinggevende technische functies & 12 & 67 & 20 & 1 \\
\hline Technisch opgeleide verkopers & 12 & 30 & 40 & 17 \\
\hline Ontwikkeling en engineering & 8 & 39 & 43 & 10 \\
\hline (Hoger) management & 23 & 31 & 35 & 12 \\
\hline $\begin{array}{l}\text { Ondersteunend, administratief of niet-technisch } \\
\text { verkooppersoneel }\end{array}$ & 5 & 34 & 52 & 9 \\
\hline
\end{tabular}

Bron: ROA/Werkgeverspanel Metalektro 2004

\section{Gebruik van inzetbaarheid}

In hoeverre wordt de bij het personeel aanwezige inzetbaarheid ook daadwerkelijk in de bedrijven benut? Om hier een beeld van te krijgen is aan de bedrijven ook gevraagd in hoeverre er gebruik gemaakt wordt van de inzetbaarheid. Tabel 7.4 geeft daarvan een overzicht.

Vooral het uitvoerend technisch personeel wordt vaak breed ingezet. Meer dan $60 \%$ van de bedrijven geeft zelfs aan dat ze vaak gebruik maken van de inzetbaarheid van hun technisch personeel, terwijl $37 \%$ aangeeft dit af en toe te doen. In vergelijking met 2003 is het gebruik van de aanwezige inzetbaarheid duidelijk gestegen. In dat jaar gaf namelijk nog meer dan een kwart van de bedrijven aan de inzetbaarheid van het uitvoerend technisch personeel slechts zelden te benutten. De leidinggevende technici worden daarentegen veel minder vaak flexibel ingezet. Bijna een kwart van de bedrijven geeft aan deze werknemers slechts zelden of helemaal nooit breder in te zetten. De overige functiecategorieën worden bij de meeste bedrijven 
slechts af en toe of zelden breed ingezet. Een opvallende regionale uitkomst is dat het ondersteunend, administratief of niet-technisch verkooppersoneel in de regio West veel vaker breed wordt ingezet dan in de andere regio's.

Tabel 7.4

Mate waarin bedrijven gebruik maken van de inzetbaarheid van hun personeel naar functiecategorie, 2004 (\% bedrijven)

\begin{tabular}{|c|c|c|c|c|}
\hline \multirow[t]{2}{*}{ Functiecategorie } & Vaak & Af en toe & Zelden & Nooit \\
\hline & $\%$ & $\%$ & $\%$ & $\%$ \\
\hline Uitvoerende technische functies & 62 & 37 & 1 & 0 \\
\hline Leidinggevende technische functies & 21 & 56 & 17 & 6 \\
\hline Technisch opgeleide verkopers & 8 & 29 & 29 & 34 \\
\hline Ontwikkeling en engineering & 12 & 35 & 35 & 17 \\
\hline (Hoger) management & 14 & 21 & 31 & 34 \\
\hline $\begin{array}{l}\text { Ondersteunend, administratief of niet-technisch } \\
\text { verkooppersoneel }\end{array}$ & 12 & 36 & 32 & 20 \\
\hline
\end{tabular}

Bron: ROA/Werkgeverspanel Metalektro 2004

Al met al kan worden geconcludeerd dat er in de metalektrobedrijven een sterke toename heeft plaatsgevonden in de mate waarin het uitvoerend technisch personeel breed wordt ingezet. Hetzelfde geldt in iets mindere mate ook voor de leidinggevende functies. Uit figuur 7.1 bleek reeds dat veel bedrijven vinden dat de flexibiliteit van hun technisch personeel in de komende jaren belangrijker wordt. Dit wijst erop dat veel bedrijven hun technisch personeel in de toekomst steeds vaker breed willen inzetten.

\section{Redenen van onderbenutting}

Toch maken niet alle bedrijven optimaal gebruik van de brede inzetbaarheid van hun personeel. Wat is hiervan de oorzaak? Figuur 7.3 laat zien dat een aanzienlijk deel van de bedrijven (26\%) op dit punt aangeven dat hun personeel toch nog niet flexibel genoeg is. $17 \%$ noemt als oorzaak dat het breder inzetten van het personeel moeilijk te plannen is, bijvoorbeeld doordat de functies zo specialistisch zijn dat het moeilijk is om het personeel breed in te zetten.

Als derde oorzaak wordt genoemd dat het vanwege bedrijfsdrukte of werkdruk moeilijk is om van de brede inzetbaarheid van het personeel gebruik te maken. Circa $10 \%$ van de bedrijven vindt dat hun technisch personeel onvoldoende geschoold is om breed te worden ingezet. Een klein aantal bedrijven vindt dat het breder inzetten van hun technisch personeel ten koste gaat van de kwaliteit van de productie. Slechts $4 \%$ van de bedrijven geeft aan dat ze geen behoefte hebben aan breed inzetbaar personeel. Ten slotte is het toch wel opmerkelijk dat één op de vijf bedrijven geen verklaring heeft voor het feit dat ze niet volledig gebruik maken van de bredere inzetbaarheid van hun personeel. 
Figuur 7.3

Oorzaken van het beperkt gebruik van de brede inzetbaarheid van het technisch personeel, 2004 (\% bedrijven)

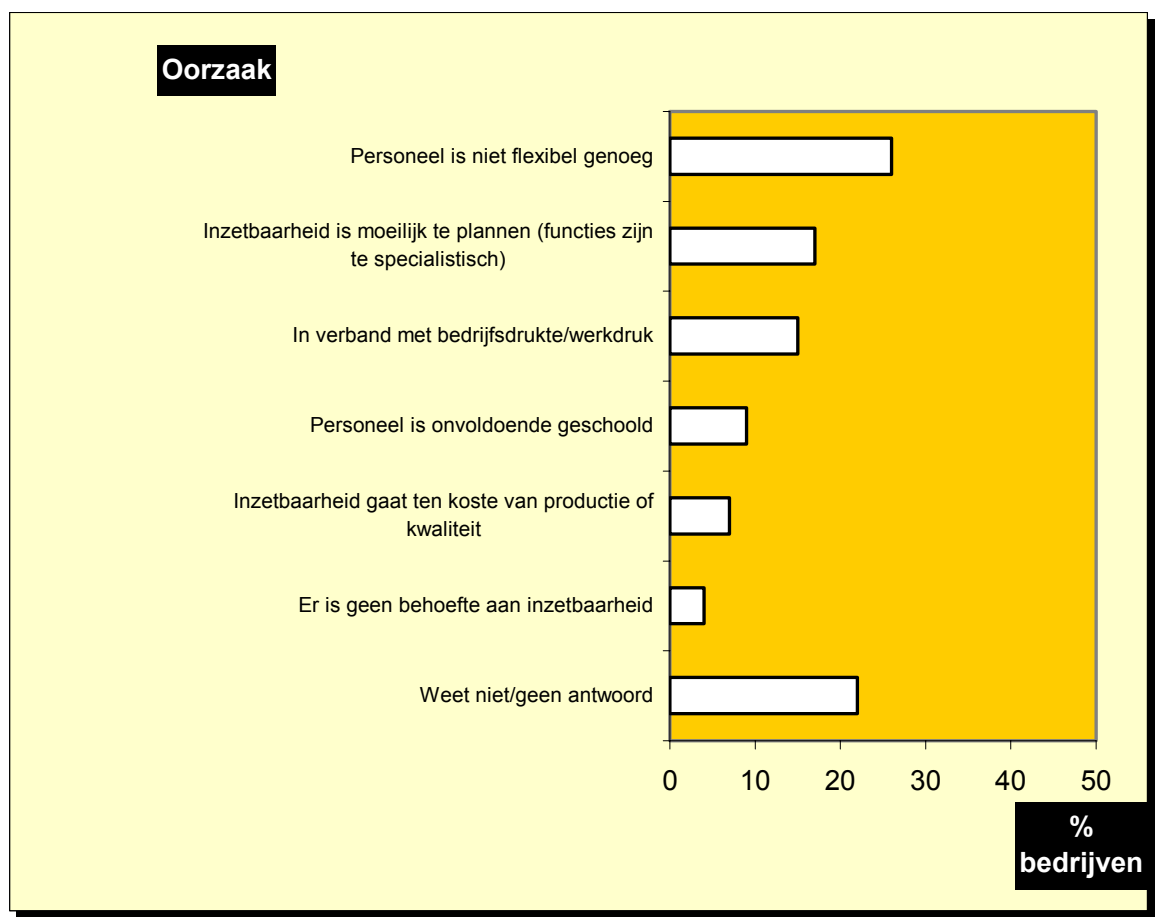

Bron: ROA/Werkgeverspanel Metalektro 2004

Uit de gesprekken met deelnemende bedrijven blijkt dat de inzetbaarheid van het personeel ook een kwestie is van de bereidheid van het personeel zelf. Zo geeft een bedrijf bijvoorbeeld aan dat ze oudere werknemers actief probeert in te zetten bij "verbeteracties" die ten doel hebben om bepaalde aspecten van het productieproces te verbeteren. Hoewel sommige werknemers dit interessant vinden, lukt het bij de meeste werknemers toch niet om ze hiervoor enthousiast te krijgen. Veel werknemers hebben een instelling van "laat mij maar gewoon lekker werken". Een ander bedrijf merkt op dat mensen die geen directe contacten hebben met de klanten van het bedrijf minder bereid zijn om zich breed inzetbaar op te stellen en ook minder "veranderingsbereid" zijn. Het bedrijf denkt dat dit te maken heeft met "achterstallig onderhoud" voor wat betreft de employability van het personeel. Er is in het betreffende bedrijf in het verleden te weinig gedaan om de noodzaak van brede inzetbaarheid voldoende naar het personeel te communiceren.

\subsection{Wat doet het HRM-beleid er toe?}

Dat bedrijven behoefte hebben aan breed inzetbaar personeel kwam al meermaals aan de orde. Naast de bereidheid en het vermogen van het personeel om zich flexibel op te stellen speelt ook het HRM-beleid van de bedrijven een belangrijke rol bij het creëren van een voldoende breed inzetbaar personeelsbestand. 93\% van de bedrijven geeft dan ook aan dat hun HRM-beleid er op gericht is om de inzetbaarheid 
van het technisch personeel te bevorderen. Tabel 7.5 geeft een overzicht van het percentage bedrijven dat gebruik maakt van bepaalde HRM-instrumenten om de inzetbaarheid van het personeel te verbreden. Daarbij wordt er onderscheid gemaakt tussen bedrijven die een HRM-instrument voor al het technisch personeel toepassen en bedrijven die dat doen voor een meerderheid van het technisch personeel.

Tabel 7.5

Gebruik van HRM-instrumenten om de brede inzetbaarheid van het technisch personeel te bevorderen, 2004 (\% bedrijven)

\begin{tabular}{rrr}
\hline HRM-instrument/gebruik & $\begin{array}{r}\text { Voor alle } \\
\text { technisch }\end{array}$ meerderheid \\
technisch \\
werknemers
\end{tabular}$\quad \begin{array}{rr}\text { werknemers } \\
\%\end{array}$

Scholing en competenties

Opleidingsfaciliteiten

Bedrijfsopleidingsplan (BOP)

Persoonlijk ontwikkelingsplan (POP)

Competentiematrix

Erkenning verworven competenties (EVC)

$\begin{array}{rr}42 & 29 \\ 47 & 23 \\ 16 & 11 \\ 18 & 15 \\ 4 & 5\end{array}$

Mobiliteit

Loopbaanplanning

Functieroulatie

Loopbaanadviescentrum of mobiliteitscentrum

Uitwisseling van werknemers met andere bedrijfsvestigingen

$\begin{array}{lr}7 & 16 \\ 9 & 39 \\ 4 & 2 \\ 2 & 4\end{array}$

Communicatie

Functioneringsgesprekken

Beoordelingsgesprekken

Scholingsgesprekken

Geregeld werkoverleg

$\begin{array}{ll}68 & 14 \\ 61 & 11 \\ 31 & 21 \\ 52 & 28\end{array}$

Bron: ROA/Werkgeverspanel Metalektro 2004

$42 \%$ van de metalektrobedrijven biedt alle technische werknemers opleidingsfaciliteiten aan om hun inzetbaarheid te vergroten, terwijl $29 \%$ van de bedrijven een meerderheid van hun technisch personeel dergelijke opleidingsfaciliteiten aanbiedt. Bijna de helft van de bedrijven beschikt over een bedrijfsopleidingsplan (BOP) dat (mede) als doel heeft om de inzetbaarheid van al het technisch personeel te bevorderen. Bij circa een kwart van de bedrijven is het BOP gericht op het verbeteren van de inzetbaarheid van een meerderheid van het personeel. Daarentegen proberen relatief weinig bedrijven de inzetbaarheid van hun technisch personeel te bevorderen door persoonlijke opleidingsplannen (POPs), een competentiematrix, of door het erkennen van de verworven competenties van het personeel (EVC). Het gebruik van een competentiematrix kan overigens wel een prima mogelijkheid zijn om de inzetbaarheid van het personeel te benutten. Een HRM-manager van een constructiebedrijf licht dat toe: "We hechten zeer aan een bredere inzetbaarheid van het personeel. Daarom maken we overzichten waarop voor iedere werknemer wordt 
aangegeven wat zijn kwaliteiten zijn. Op die manier is het duidelijk wat iemand kan en waar hij eventueel flexibel kan worden ingezet".

Relatief weinig bedrijven gebruiken HRM-instrumenten op het vlak van personeelsmobiliteit om de inzetbaarheid van hun technisch personeel te vergroten. Zo is er bijvoorbeeld in slechts $6 \%$ van de bedrijven sprake van een uitwisseling van werknemers met andere bedrijven. Ook heeft slechts $6 \%$ van de bedrijven een loopbaanadviescentrum of mobiliteitscentrum. Bovendien doet slechts $7 \%$ van de bedrijven voor al hun technisch personeel aan loopbaanplanning. 16\% van de bedrijven doet dit overigens wel voor een meerderheid van het technisch personeel. Op het terrein van de personeelsmobiliteit is functieroulatie het HRM-instrument dat het meest wordt toegepast om de inzetbaarheid van het personeel te vergroten. Bijna de helft van de bedrijven rouleert (een meerderheid van) het technisch personeel om zo hun inzetbaarheid te vergroten.

De verschillende HRM-instrumenten gericht op de interne communicatie worden verreweg het meest ingezet om de inzetbaarheid van het technisch personeel te vergroten. Ruim de helft van alle bedrijven probeert via functioneringsgesprekken, beoordelingsgesprekken of werkoverleg de inzetbaarheid van alle technische werknemers te stimuleren. 


\section{$8 \quad$ Agenda voor de Toekomst}

In dit hoofdstuk formuleren we enkele belangrijke aandachtspunten voor het arbeidsmarkt- en personeelsbeleid in de Nederlandse metalektro-industrie in de vorm van een Agenda voor de Toekomst. Deze agenda vormt de leidraad voor het personeelsbeleid dat vereist is voor het behouden en vergroten van het concurrerend vermogen van de Nederlandse Metalektrosector.

\subsection{Competent en breder inzetbaar}

In de Arbeidsmarktmonitor Metalektro 2003 kwam reeds naar voren dat de Nederlandse metalektro-industrie geconfronteerd wordt met een snel voortschrijdende toename van de competentie-eisen. Uit de monitor van 2004 blijkt dat naast de toename van de vereiste vaktechnische competenties, het overgrote deel van de bedrijven vooral geconfronteerd wordt met een sterk groeiende behoefte aan personeel dat: (1) kan omgaan met veranderingen, (2) beschikt over voldoende probleemoplossend vermogen en (3) in staat is om initiatief te nemen wanneer dat nodig is. Een aanzienlijk deel van de bedrijven is zich er van bewust dat ze de komende jaren juist op deze punten geconfronteerd zullen worden met competentietekorten van hun technisch personeel.

Het is belangrijk om te beseffen dat de urgentie van deze niet louter vaktechnische competentietekorten voor veel bedrijven zeer groot is. Om concurrerend te blijven zullen bedrijven bij voorkeur pro-actief moeten kunnen inspelen op de aanpassingen in de producten en productieprocessen die afzetmarkten eisen en in ieder geval over voldoende flexibiliteit beschikken om hier adequaat op in te kunnen spelen.

Het technisch personeel in de metalektro-industrie moet daarom in aanvulling op de gewenste vaktechnische bijscholing in staat worden gesteld hun gedragsmatige competenties verder te ontwikkelen. De vereiste competentie-ontwikkeling heeft vanzelfsprekend grote gevolgen voor de scholingsagenda van de Nederlandse metalektro-industrie. Het versterken van de concurrentiepositie van de metalektrobedrijven vereist de opzet en invulling van, wat zou kunnen worden aangeduid als de POFI-Agenda. Deze POFI-Agenda zal zich moeten richten op de vier competenties van de toekomst:

- Probleemoplossend vermogen

- Omgaan met veranderingen

- Flexibiliteit

- Initiatief

De POFI-Agenda zal overigens niet alleen betrekking hebben op het volgen van trainingen en cursussen. Minstens zo belangrijk is het stimuleren van het informeel leren. Dit geldt bij uitstek voor de POFI-competenties. Ook het bevorderen van het coachend leiderschap op de werkvloer zal hier een belangrijke rol bij kunnen spelen. Meer dan de helft van de metalektrobedrijven ziet het bevorderen van coachend 
leiderschap reeds als een van de speerpunten van hun HRM-beleid voor de komende 5 jaar.

Uit onderzoek blijkt dat het informeel leren tijdens het werk in het algemeen erg belangrijk is voor de competentie-ontwikkeling van werkenden. Echter, het volgen van een cursus of training blijkt aan dit informeel leren een belangrijke impuls te kunnen geven. Dit betekent dat er in de toekomst meer aandacht zal moeten zijn voor combinaties van verschillende manieren van leren om de benodigde competentieontwikkeling te realiseren. Vooral voor de gesignaleerde toekomstige POFI-tekorten is het van groot belang dat niet alleen de kennisoverdracht centraal staat, maar dat ook het gedragsmatige handelen voldoende aandacht krijgt. Dat pleit voor het vinden van combinaties van formele cursussen en trainingen, 'learning-by-doing', informeel leren tijdens het werk, en coaching door leidinggevenden. Pas wanneer leren en werken minder als gescheiden bedrijfsprocessen gezien worden en wanneer de werkvloer ingericht wordt als een 'leerrijke werkomgeving' zullen de metalektrobedrijven erin slagen om de toekomstige competentietekorten van hun personeel op een efficiënte wijze aan te pakken.

De ontwikkeling van competenties hoeft overigens niet uitsluitend betrekking te hebben op het verhogen van het opleidingsniveau van de werknemers. Voor laagopgeleiden waarbij het niet mogelijk of noodzakelijk is om een niveauverhogend scholingstraject te voltooien zal er echter ook aandacht moeten zijn voor de ontwikkeling van de competenties. Vooral het verbeteren van de POFI-competenties is daarbij van groot belang. Ook aan oudere werknemers moet er voldoende aandacht worden blijven besteed. Wanneer deze werknemers niet kunnen of hoeven worden bijgeschoold tot een hoger niveau moet er in ieder geval voor gezorgd worden dat ze beschikken over de competenties die de bedrijven nodig hebben en dat ze voldoende breed inzetbaar zijn.

Naast de ontwikkeling van competenties is het natuurlijk ook van groot belang dat de metalektrobedrijven een goed beeld hebben van de kennis en vaardigheden die ze met hun huidige personeel al in huis hebben. Wat dit betreft is het goed om te zien dat de Erkenning van Verworven Competenties (EVC) de komende jaren in een "take-off" fase terecht komt, waarin het breder verspreid raakt in de metalektrosector. Hoewel het gebruik van EVC in de Metalektro op dit moment nog bescheiden is, noemt wel maar liefst een kwart van de metalektrobedrijven EVC als een van de speerpunten van hun HRM-beleid voor de komende jaren.

\subsection{Opscholen instroom en zittend personeel}

De naar verwachting aanzienlijke uitstroom van oudere werknemers als gevolg van (pré-)pensionering betekent dat de metalektrobedrijven ook voldoende aandacht moeten hebben voor de competenties van de schoolverlaters die de Metalektro de komende jaren zullen instromen. De meerderheid van de bedrijven werkt nu al samen met onderwijsinstellingen. Dit laat zien dat het belang van de kwaliteit van de instroom terdege wordt onderkend. Wel zou er nog meer dan nu het geval is kunnen worden samengewerkt met onderwijsinstellingen, om ervoor te zorgen dat de 
leerlingen van het technisch onderwijs opleidingen volgen die zowel qua richting als niveau beter afgestemd zijn op de toekomstige personeelsbehoefte in de sector. Wat dit betreft is het zeer zorgelijk dat er de komende jaren met name voor de middenkader- en specialistenopleidingen op het hoogste MBO-niveau een dalende instroom wordt verwacht, terwijl het aanbod van schoolverlaters van bepaalde VMBO-opleidingen naar verwachting juist zal toenemen. Dit staat in schril contrast met de upgrading van de functie-eisen en de behoefte in de metalektrobedrijven aan personeel met minimaal een opleiding op niveau 3. De intensivering van de contacten met het onderwijsveld kan er toe bijdragen dat de toekomstige werknemers van de Metalektro adequaat opgeleid worden en beschikken over die competenties die de bedrijven in de toekomst zo hard nodig hebben. Dit te meer daar de overheid recentelijk heeft uitgesproken dat ook degenen die al tot de arbeidsmarkt zijn toegetreden altijd via het door de overheid bekostigd onderwijs een MBO diploma moeten kunnen halen (zie Ministerie van OC\&W, Actieplan Leven Lang Leren, november 2004).

Hoewel veel bedrijven nu al samenwerken met onderwijsinstellingen is de samenwerking nog onvoldoende gericht op de competenties van de schoolverlaters. Meer aandacht daarvoor kan er toe bijdragen dat de aansluiting tussen wat het instromende personeel geleerd heeft en wat de bedrijven nodig hebben, verbetert. Daarnaast zullen de metalektrobedrijven zelf ook aandacht moeten besteden aan het verder 'opscholen' van de schoolverlaters die ze aantrekken.

Voor de bedrijven die hiertoe de mogelijkheid hebben zal het ook aantrekkelijk zijn via een "bedrijfsacademie" te voorzien in het nieuwe personeel dat ze nodig hebben. Dit zal ongetwijfeld de arbeidsmarktpositie van deze bedrijven kunnen versterken en kan bijdragen tot het verwerven van een competent en breed inzetbaar personeelsbestand. Wanneer de bedrijfsacademies meer gericht worden op competentieverwerving in het algemeen, kan er beter en sneller ingespeeld worden op de toekomstige competentiebehoefte van de bedrijven.

\subsection{Kennisoverdracht en doorstroom}

De toenemende vergrijzing in de Metalektro en de daarmee gepaard gaande personeelsuitstroom, leidt er in de nabije toekomst ook toe dat bepaalde bedrijven wervingsproblemen zullen krijgen en dat er bij sommige bedrijven waardevolle ervaringskennis verloren zal gaan. Om de gevolgen daarvan te beperken is het belangrijk dat deze bedrijven hun oudere personeel voldoende mogelijkheden geven om hun kennis over te dragen op de jongere generaties. Het blijkt dat sommige bedrijven dit al in grote mate in de praktijk brengen, bijvoorbeeld door het oudere personeel door te laten stromen naar functies waarin het coachen van jongere collega's centraal staat.

De komende jaren zal het overigens ook veel moeilijker worden om ouder personeel dat moeite krijgt met het werktempo of fysiek belastende arbeidsomstandigheden, vroegtijdig te laten uitstromen. Ook dit maakt het belangrijk om, voor zover dat mogelijk is, ouderen te laten doorstromen naar minder belastende functies. Toch 
blijkt de interne doorstroom van personeel in de metalektrosector als geheel nog op een erg laag niveau te liggen. HRM-beleid dat gericht is op het vergroten van de doorstroom kan er toe bijdragen dat, voor zover dit noodzakelijk is, ervaring van oudere werknemers kan worden overgedragen aan jongeren vóórdat het oudere personeel de Metalektro verlaat. Een grotere doorstroom zal er bovendien toe leiden dat niet alleen de employability van het oudere personeel verbetert, maar in feite de inzetbaarheid van het hele personeelsbestand zal toenemen. Het kan daarmee ook bijdragen aan het realiseren van de flexibiliteitsbehoefte die voor veel bedrijven de komende jaren erg belangrijk zal worden.

\subsection{Flexibel in omvang}

Flexibiliteit kan ook gerealiseerd worden door het inzetten van tijdelijk personeel, bijvoorbeeld door gebruik te maken van werknemers die via een uitzendbureau in de bedrijven aan de slag gaan. De tijdelijke inzet van personeel als aanvulling op het reguliere personeelsbestand bij pieken in de bedrijfsdrukte, is inmiddels een fenomeen dat in de Metalektro wijd verbreid is. Wel gaat het daarbij meestal om personeel dat de bedrijven via uitzend- of detacheringsbureaus aantrekken. Een andere voor de hand liggende oplossing om het aantal werknemers flexibel te kunnen afstemmen op de fluctuerende personeelsbehoefte is het tijdelijk inlenen van personeel van andere bedrijven in de regio. Deze manier om flexibiliteit in de omvang van het personeelsbestand te realiseren heeft grote voordelen: Enerzijds leidt het tot grote kostenbesparingen bij het inlenen van personeel. Anderzijds leidt het tot de mogelijkheid om tijdens minder drukke periodes een deel van het personeel uit te lenen aan andere bedrijven en zo te besparen op de vaste personeelskosten. Ondanks de potentiële voordelen, wordt er echter momenteel in de Metalektro nog relatief weinig gebruik gemaakt van collegiale in- en uitleen.

De ontwikkeling en verdere uitbouw van de op metalektro gerichte bemiddelingsinstrumenten kunnen ertoe bijdragen dat metalektrobedrijven in de toekomst een groot deel van de benodigde personeelsflexibiliteit kunnen gaan realiseren door collegiale in- en uitleen van hun personeelsbestand. Ook de uitbouw van detacheringsarrangementen vanuit commerciële organisaties die zich richten op de bedrijven in de Metalektro of de industrie in het algemeen kan een belangrijke bijdrage leveren aan de toekomstige flexibiliteit in de personeelsomvang van de metalektrobedrijven. Wanneer blijkt dat er in de toekomst op de Nederlandse arbeidsmarkt onvoldoende personeel beschikbaar is, kan arbeidsmigratie een gevolg zijn. Dat zou dan wel aanpassingen in de regelgeving van de overheid vergen.

\subsection{De Agenda voor de Toekomst: competent en breder inzetbaar}

De missie van de Agenda voor de Toekomst voor de Nederlandse metalektroindustrie kan als motto dragen: competent en breder inzetbaar. Het realiseren van deze beide doelstellingen zal bepalend zijn voor het toekomstig succes van de Nederlandse metalektrobedrijven. Deze Agenda voor de Toekomst omvat de volgende cruciale bestanddelen: 
1. De POFI-Agenda, gericht op het versterken van het competentieniveau van het personeel, met betrekking tot de vier competenties waaraan bedrijven in de toekomst vooral behoefte hebben:
a. probleemoplossend vermogen
b. omgaan met veranderingen
c. flexibiliteit
d. initiatief

2. Opleidingen en trainingen moeten beter gaan aansluiten op de competenties die bedrijven (in de toekomst) nodig hebben.

3. Naast formele cursussen en trainingen zou er meer aandacht moeten komen voor informele manieren van kennisverwerving, zoals coaching, en 'learning by doing'. Wanneer deze informele scholing gecombineerd wordt met formele cursussen ontstaat er in de bedrijven een 'leerrijke werkomgeving' waarin leren en werken een strategisch geheel vormen.

4. Het opscholen van de instroom van schoolverlaters naar het voor een optimaal functioneren vereiste competentieniveau; Recentelijk heeft de overheid aangegeven dat ook werkenden altijd via het door de overheid bekostigd onderwijs een MBO diploma kunnen halen.

5. Het aandacht blijven houden voor laagopgeleide en oudere werknemers. Wanneer deze groepen niet kunnen worden bijgeschoold tot een hoger niveau, moet er zorg voor gedragen worden dat ze voldoende breed inzetbaar zijn en wel beschikken over de competenties die de bedrijven op de lagere functieniveaus nodig hebben.

6. Het vergroten van de doorstroom van het personeel om de brede inzetbaarheid van het personeel te vergroten. Doorstroom van ouder personeel naar minder belastende functies kan er toe bijdragen dat oudere werknemers langer productief aan het werk kunnen blijven.

7. Verdere uitbouw van HRM-instrumenten die de brede inzetbaarheid bevorderen: loopbaan/carrière planning, functieroulatie, EVC, coachend leidinggeven, competentiemanagement en uitwisseling van werknemers. 